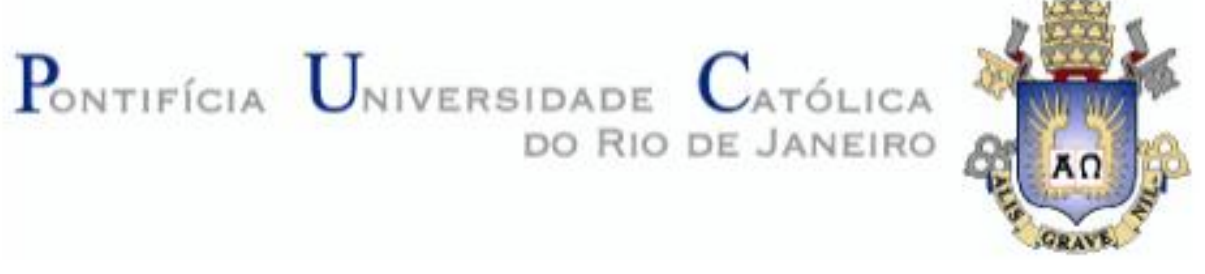

\author{
Michelle de Moraes Ferraz
}

\title{
Juventude, Cultura Cívica e Cidadania: \\ 15 anos depois
}

Dissertação de Mestrado

Dissertação apresentada ao Programa de Pósgraduação em Ciências Sociais da PUC-Rio como requisito parcial para obtenção do título de mestre em Ciências Sociais.

Orientadora: Prof ${ }^{a}$ Angela Maria Randolpho Paiva 


\title{
Pontifícia U Uiversidade Católloa $_{\text {a }}$

\section{Juventude, Cultura Cívica e Cidadania: \\ 15 anos depois}

\begin{abstract}
Dissertação apresentada como requisito parcial para obtenção do grau de Mestre pelo Programa de Pós-graduação em Ciências Sociais do Departamento de Ciências Sociais do Centro de Ciências Sociais da PUC-Rio. Aprovada pela Comissão Examinadora abaixo assinada:
\end{abstract}

Profa. Angela Maria de Randolpho Paiva Orientadora Departamento de Ciências Sociais - PUC-Rio

Prof. Marcelo Tadeu Baumann Burgos

Departamento de Ciências Sociais - PUC-Rio

Profa. Regina Celia Reyes Novaes

Universidade Federal do Estado do Rio de Janeiro - UNIRIO

Rio de Janeiro, 14 de outubro de 2020 
Todos os direitos reservados. É proibida a reprodução total ou parcial do trabalho sem autorização da universidade, do autor e do orientador.

\section{Michelle de Moraes Ferraz}

Graduou-se em Ciências Sociais pela Pontifícia Universidade Católica do Rio de Janeiro em 2007. Cursou a especialização em Residência Docente (PRD) pelo colégio Pedro II. Ingressou no curso de mestrado em Ciências Sociais da PUC-Rio no ano de 2018. É professora de Sociologia na rede estadual de ensino, no Rio de Janeiro.

Ficha Catalográfica

Ferraz, Michelle de Moraes

Juventude, cultura cívica e cidadania : 15 anos depois / Michelle de Moraes Ferraz ; orientadora: Angela Maria Randolpho Paiva. - 2020. 133 f. : il. color. ; $30 \mathrm{~cm}$

Dissertação (mestrado)-Pontifícia Universidade Católica do Rio de Janeiro, Departamento de Ciências Sociais, 2020.

Inclui bibliografia

1. Ciências Sociais - Teses. 2. Juventude. 3. Cultura cívica. 4. Cidadania. 5. Desigualdades sociais. 6. Educação. I. Paiva, Angela Randolpho. II. Pontifícia Universidade Católica do Rio de Janeiro. Departamento de Ciências Sociais. III. Título. 
A luz da dor

O meu modo de saber é adoecendo.

A uns, a ideia surge em luz.

A mim, se declara uma pontada no peito.

O advento da dor, o deflagrar da súbita febre e eu sei que meu corpo sabe.

Um dia destes me desconhecerei vivo desfalecido de aguda sapiência.

Até lá repartirei com um anjo o doce milagre da refeição

\section{Mia Couto}




\section{Agradecimentos}

A Jesus e Maria, meus maiores exemplos na vida.

À minha orientadora Angela Paiva que é mais que orientação, é luz, amor e inspiração.

Ao professor Marcelo Burgos e à professora Regina Novaes que empreenderam leituras atentas e prestaram generosa contribuições acerca de meu trabalho de dissertação desde o momento em que aceitaram fazer parte da banca.

Ao Departamento de Ciências Sociais e por todos os profissionais, sobretudo à Ana Roxo, que se dedicam cada dia em construir e manter esse lugar tão especial e necessário.

À Pontifícia Universidade Católica por ter, mais uma vez, me acolhido. Eu me sinto mais em casa aqui do que em qualquer outro lugar.

A elas que fazem desenhos beeem pequeninos no meio das folhas dos meus textos, que "pintam" páginas inteiras dos meus livros, que falham minhas canetas fluorescentes e somem com um tanto de coisas que não acho mais. Poderia ser caos, mas é poesia, é vida, aliás são duas vidas: Maria Sophia e Pietra!

Agradeço por todo "caos" que promovem em minha vida. Agradeço por todas as vezes que me tiraram da frente do computador para ver um bichinho diferente na árvore do quintal, para fazer pipoca, para assistir uma manobra nova com o patinete, para ajudar no dever da escola, para contar uma história sem fim. Cada vez que me tiraram a atenção do trabalho, me conduziram para a vida.

À minha primogênita que responde por minha irmã. Monike (Cotita) que é força e beleza. Meu elo mais lindo com as memórias do passado e guardiã da esperança no futuro. Só nós sabemos como chegamos, dignamente, até aqui.

Ao Joaquim, que é puro coração e ajuda a completar o "caos" da minha vida. 


\section{Resumo}

Ferraz de Moraes, Michelle; Paiva, Angela Maria Randolpho. Juventude, Cultura Cívica e Cidadania: 15 anos depois. Rio de Janeiro, 2020, 111p. Dissertação de Mestrado - Departamento de Ciências Sociais, Pontifícia Universidade Católica do Rio de Janeiro.

A pesquisa Juventude, Cultura Cívica e Cidadania utiliza as metodologias quantitativa e qualitativa para auscultar as percepções dos jovens sobre os temas relacionados à cultura cívica e à cidadania. Os jovens que compõem o público alvo da pesquisa são alunos da rede pública e particular de escolas localizadas em três regiões do Rio de Janeiro. A hipótese central é a de que as desigualdades sociais impactam na percepção dos jovens sobre os temas propostos pela pesquisa. Nesse trabalho, foi realizada uma comparação entre os dados obtidos pela mesma pesquisa em 2004 e os dados coletados a partir de 2019.

\section{Palavras-chave}

Juventude; cultura cívica; cidadania; desigualdades sociais; educação. 


\section{Abstract}

Ferraz de Moraes, Michelle; Paiva, Angela Maria Randolpho (Advisor). Youth, civic culture and citizenship: 15 years later. Rio de Janeiro, 2020, 111p. MSc. Dissertation - Departamento de Ciências Sociais, Pontifícia Universidade Católica do Rio de Janeiro.

The Youth, Civic Culture and Citizenship research uses quantitative and qualitative methodologies to listen to young people's perceptions about topics related to civic culture and citizenship. The young people who make up the target audience of the research are students from public and private High schools located in three regions of Rio de Janeiro. The central hypothesis is that social inequalities impact the perception of young people on the themes proposed by the research. In this work, a comparison was made between the data obtained by the same research in 2004 and the data collected from 2019 on.

\section{Keywords}

Youth; civic culture; citizenship; social differences; education. 


\section{Sumário}

1. Introdução 10

$\begin{array}{ll}\text { 1.1 Metodologia da pesquisa } & 15\end{array}$

2. Juventude: a construção social de um conceito no plural 19

2.1. A construção do conceito de juventude na sociologia brasileira 28

2.2 Desigualdades e simetrias: uma comparação dos primeiros resultados 46

3. A historicidade do conceito de cidadania 59

3.1. Dilemas da cidadania no Brasil 70

3.2. As desigualdades influenciam na percepção dos jovens sobre a cidadania? Alguns resultados da pesquisa 82

4. Cultura cívica: do que se trata? 90

4.1. Problematizando a cultura cívica no Brasil 95

4.2. O que o campo nos informa sobre a cultura cívica na perspectiva dos jovens? 98

Conclusão 112

$\begin{array}{ll}\text { Referências Bibliográficas } & 116\end{array}$

Anexos 


\section{Lista de gráficos e tabelas}

Tabela 1: Ser jovem no Brasil é - pesquisa atual 58

Tabela 1.1: Ser jovem no Brasil é - pesquisa anterior $\quad 59$

Tabela 2.0: Escolaridade dos pais - pesquisa anterior $\quad 60$

Gráfico 2.0: Confiança na escola - pesquisa atual $\quad 61$

Gráfico 2.1: Confiança na escola - pesquisa anterior $\quad 62$

Gráfico 2.2: Confiança na universidade - pesquisa atual e
anterior

Tabela 3.0: Problemas do país - pesquisa anterior $\quad 64$

Tabela 3.1: Problemas do país - pesquisa atual 68

Tabela 4.0: Ser cidadão - Pesquisa anterior $\quad 69$

Tabela 4.1: Ser cidadão - pesquisa atual $\quad 92$

Gráfico 3.0: Cidadania e respostas que aumentaram $\quad 92$

Gráfico 3.1: Cidadania e respostas que reduziram 95

Tabela 5.0: Direitos por rede de ensino $\quad 96$

Gráfico 4.0: Concentração e mudança nos tipos de direitos $\quad 97$

Gráfico 5.0: Você vota? $\quad 97$

Gráfico 5.1: Pretende tirar o título antes de completar 18 anos? 98

Gráfico 5.2: Opinião sobre o voto 98

Tabela 6.0: Deveres por rede de ensino 99

Gráfico 6.0: Deveres por rede de ensino pesquisa anterior $\quad 100$

Gráfico 6.1: Deveres por rede de ensino pesquisa atual $\quad 100$

Gráfico 7.0: Sobre a democracia - pesquisa anterior $\quad 108$

Gráfico 7.1: Sobre a democracia - pesquisa atual 108

Gráfico 8.0: Confiança na polícia - pesquisa atual 109

Gráfico 8.1: Confiança nos militares - pesquisa atual 109

Gráfico 8.3: Confiança no judiciário - pesquisa atual $\quad 110$

Gráfico 8.4: Confiança nos partidos - pesquisa anterior 111

Gráfico 8.5: Confiança nos partidos - pesquisa atual $\quad 111$

Gráfico 9.0: Avaliação dos políticos - pesquisa anterior $\quad 111$

Gráfico 9.1: Avaliação dos políticos - pesquisa atual 111

Gráfico 9.2: Atuação dos políticos - pesquisa anterior $\quad 113$

Gráfico 9.3: Atuação dos políticos - pesquisa atual 113

Gráfico 10: Critério de escolha de candidato - pesquisa atual 113

Gráfico 11.0: Tipo de participação - pesquisa anterior $\quad 114$

Gráfico 11.1: Tipo de participação - pesquisa atual $\quad 114$

Gráfico 12.0: Uso da internet - rede pública $\quad 115$

Gráfico 12.1: Uso da internet - rede particular $\quad 115$

Gráfico 13.0: Sentimento pelo país por rede - pesquisa anterior $\quad 115$

Gráfico 13.1: Sentimento pelo país por rede - pesquisa atua 117

Gráfico 14.0: Morar em outro país - rede pública $\quad 118$

Gráfico 14.1: Morar em outro país - rede particular $\quad 118$

Gráfico 14.2: Motivos para morar em outro país - rede pública $\quad 118$

Gráfico 14.3: Motivos para morar em outro país - rede

particular 
1.

\section{Introdução}

“O que a juventude nos pode dar? O que a juventude pode esperar de nós?” Com essas duas perguntas, Karl Mannheim introduz seu texto "O problema da juventude na sociedade moderna". As perguntas de Mannheim lançam luz sobre os motivos que nos incentivam a estudar juventude. Queremos saber o que esperar dela; ruptura ou continuidade? Inovação ou manutenção? Também nos preocupamos com suas potencialidades; de que modo podemos orientá-la, apoiá-la ou, até mesmo, controlá-la.

O tema da juventude é complexo em todos os enfoques, seja na perspectiva da História, da Biologia ou da Psicologia, mas é no âmbito das Ciências Sociais que ela se potencializa e adquire sua característica fundamental, que é a ênfase na sua pluralidade e desde o século XIX, as Ciências Sociais tomaram para si a árdua tarefa de estuda-la. Mas como? De que modo podemos estudar uma pluralidade que se constitui em movimento? A juventude é pluralidade, e por isso devemos sempre falar em juventudes, porque sua composição dependerá do contexto histórico, das condições materiais, dos aspectos culturais, das relações geracionais, e tantas outras questões que a influenciam. Ela se constitui em movimento, o jovem não é mais criança e ainda não é adulto, é uma transição, sendo assim, retomamos a pergunta feita anteriormente: como estudar a pluralidade em movimento? Diversas estratégias metodológicas foram desenvolvidas diante da necessidade de compreender ou "capturar" as juventudes. Sua característica natural de ser dinâmica, faz do cientista social que se debruça sobre esse tema, uma espécie de pintor que precisa dar conta de toda beleza e movimento de uma paisagem em ação.

Motivada, de certo modo, pelas perguntas de Mannheim, iniciou em 2004, no Departamento de Ciências Sociais da PUC-Rio, o projeto de pesquisa Juventude, Cultura Cívica e Cidadania. A proposta principal da pesquisa era auscultar jovens que nasceram em um ambiente democrático consolidado, ou seja, aqueles que disfrutavam de uma estabilidade democrática de 15 anos, a contar da eleição do primeiro presidente eleito democraticamente. Em 2004, os jovens com idade entre 15 e 16 anos eram os primeiros a experimentar mais de uma década de democracia e a pesquisa buscava captar suas percepções sobre os temas relacionados à cidadania e cultura cívica. Será que confiam nas instituições? Em quais não confiam? Acreditam na democracia? 
Acham o voto importante? Sabem dizer quais são seus direitos e deveres? Essas eram algumas das perguntas que ajudaram a formular um questionário com 40 questões.

Além disso, havia uma situação que não poderia ser ignorada: a desigualdade social persistente que se arrastou por esses anos de consolidação democrática. Desse modo, a pesquisa é desenvolvida com um recorte especial ao formular a hipótese sobre os possíveis impactos da desigualdade na percepção dos jovens.

A escola foi estabelecida como o campo da pesquisa, visto que nela poderíamos encontrar o jovem "sobrevivente cognoscente". Aquele que consegue chegar ao ensino médio, sobretudo na escola pública. É um sobrevivente de uma sociedade desigual e de um sistema que exclui, mas não é só isso: ele também é um sujeito que atingiu um nível educacional acima da média nacional, por isso trata-se de um sujeito cognoscente, capaz de fazer avaliações e de ser reflexivo sobre temas que estão no seu entorno. Sendo assim, a pesquisa definiu como público alvo, os jovens com idade entre 15 e 17 anos, estudantes da rede pública e privada de escolas de Ensino Médio localizadas em três regiões do Rio de Janeiro: Zona Sul, Zona Oeste (Barra da Tijuca) e Zona Norte (Tijuca) ${ }^{1}$.

Em sua primeira fase, a pesquisa esteve em 20 escolas, coletou mais de mil questionários e realizou 14 grupos focais. Em 2005, a pesquisa iniciou uma segunda fase, na qual abrangeu 4 escolas públicas "de excelência” para testar nova hipótese: a de que os jovens dessas escolas teriam percepções mais próximas dos jovens da rede particular do que da rede pública estadual. Os resultados consolidados da pesquisa foram divulgados em um livro homônimo ao título da pesquisa.

Diante de um robusto conjunto de informações compostos por dados quantitativos, qualitativos e artigos, propus, por meio desta dissertação, retomar a pesquisa e realizar a comparação entre os dados da primeira pesquisa com dados atuais. Teríamos, assim, de um lado dados obtidos 15 anos após a promulgação da Constituição de 1988 e, do outro, os dados atuais, obtidos 15 anos após a realização da primeira pesquisa, desse modo, nossa pesquisa recebeu o título: Juventude, Cidadania e Cultura Cívica: 15 anos depois. Tendo em vista o prazo conciso do mestrado, estabelecemos uma redução do escopo da pesquisa. Desse modo, nos propomos a aplicar cerca de 360 questionários em 12 escolas, sendo estas, 4 escolas da rede pública estadual, 6 escolas da rede particular e 2 da rede pública de excelência. Com relação aos grupos focais, estabelecemos a realização de 6 , sendo 3 em

\footnotetext{
${ }^{1}$ Essas regiões foram escolhidas por possuírem, de acordo com o IPP (Instituto Pereira Passos), um IDS (índice de desenvolvimen to social) aproximado. Fonte: 
escolas da rede particular, 2 na rede pública estadual e 1 em escola da rede pública de excelência.

Mantendo os critérios metodológicos da primeira pesquisa, apresentamos as hipóteses para possíveis mudanças e permanências nas percepções dos jovens. Essas hipóteses foram formuladas a partir de três pilares: a) trinta anos de consolidação democrática e as desigualdades persistentes, b) a presença da internet, sobretudo das redes sociais, entre os jovens, c) a obrigatoriedade do ensino de Sociologia no Ensino Médio. Os trinta anos de consolidação democrática e as desigualdades persistentes eram a base para a nossa hipótese sobre as percepções dos jovens que não mudaram, ou seja, para as permanências. A internet e a inserção (obrigatória) do ensino de Sociologia orientaram nossas hipóteses sobre as possíveis mudanças nas percepções dos jovens.

A escola como campo de pesquisa apresenta potencialidades e desafios. As potencialidades se concentraram na questão da infraestrutura e da logística, visto que poderíamos aplicar os questionários em uma sala com mesas e cadeiras e ter uma média de 30 questionários aplicados de uma única vez. Com relação aos desafios, podemos apontar a própria dinâmica da escola, com seus calendários apertados que incluem semanas de provas, duas férias anuais e uma série de outras atividades que tornam o agendamento um dos maiores desafios. Contudo, na pesquisa atual, fomos surpreendidos por um desafio em escala global: a pandemia de Covid-19. As medidas de segurança orientadas pela OMS (organização Mundial de Saúde) fizeram com que o Governo do Estado do Rio de Janeiro, por meio do decreto 46.973 de 16 de março, antecipasse o recesso escolar de junho e, em seguida, autorizasse a modalidade de ensino remoto para todas as escolas da rede pública e privada. Nesse momento, a pesquisa havia cumprido cerca de $75 \%$ das aplicações dos questionários e $30 \%$ dos grupos focais. Diante de uma circunstância que estava além do nosso controle, encerramos as atividades de campo sem a aplicação dos questionários nas duas escolas da rede pública de excelência e sem realizar os grupos focais nas escolas públicas estaduais, mas contabilizando a aplicação de 250 questionários em 9 escolas, sendo 5 da rede privada e 4 da rede pública, além de 2 grupos focais realizados em escolas particulares.

Entendemos que a ausência dos dados das escolas públicas de excelência e dos demais grupos focais impactaram, temporariamente, no desenvolvimento da pesquisa, mas não inviabilizaram a realização desta dissertação. Certamente a pesquisa será retomada num futuro próximo e esses dados restantes serão obtidos. Porém, para efeito do presente estudo, utilizaremos todos os dados coletados até o momento da suspensão dos trabalhos de campo e reforçaremos a análise bibliográfica dos conceitos norteadores da pesquisa. Desse modo, 
nosso trabalho será organizado em três capítulos, em cada um deles apresentamos um conceito norteador da pesquisa, inicialmente, a partir da perspectiva de autores clássicos da sociologia, em seguida, ajustamos o foco da análise para o contexto brasileiro, por meio do enfoque de autores nacionais e finalmente apresentaremos os dados da pesquisa em um diálogo entre a teoria e o campo, a partir das percepções dos jovens sobre os temas abordados.

No segundo capítulo, apresentaremos o conceito de juventude. Partindo da análise dos autores clássicos, Karl Marx e Emile Durkheim, apontaremos o que identificamos como o "primeiro olhar" da sociologia para a juventude. Em seguida, complementamos a análise por meio da abordagem antropológica de Margareth Mead. Aprofundamos a análise por meio das contribuições elaboradas em dois importantes centros de pesquisa social: Escola de Chicago e Centro de Estudos Culturais Contemporâneos da Universidade de Birminghan (CCCS), que nos possibilitou entender um recorte nos estudos sobre juventude a partir de três conceitos: cultura juvenil, subculturas juvenis e contracultura. $\mathrm{O}$ objetivo é mostrar o esforço desses centros de pesquisa em estudar a juventude. Finalmente, apresentamos as definições de juventude de Karl Mannheim e Pierre Bourdieu como marcos fundamentais para o estudo do tema.

Na segunda parte desse capítulo, ajustamos o foco da análise sobre o conceito de juventude para o contexto brasileiro e iniciamos nossa discussão a partir dos autores, Otávio Ianni e Maria Alice Foracchi, que definimos como clássicos, devido às suas valiosas contribuições e por seu pioneirismo em abordar o tema da juventude. Seguindo nossa análise, chegamos a dois marcos fundamentais que foram os responsáveis pela mudança no entendimento sobre a juventude no Brasil: são eles a Constituição de 1988 e o Estatuto da Criança e do Adolescente (ECA). Finalmente, encerramos a parte teórica apresentando novos marcos que informam uma nova relação entre o Estado e os jovens. Os dados da pesquisa que traremos para reforçar e ilustrar a discussão teórica deste capítulo são: "o que é ser jovem no Brasil?", “escolaridade dos pais", “confiança na escola", "confiança na universidade” e "principais problemas do país".

No terceiro capítulo, abordaremos o conceito de cidadania. Nossos autores clássicos para esse percurso são T.H. Marshall e Reinhard Bendix e serviu para ampliações conceituais e críticas. A abordagem de Marshall traz uma tipologia importante para o conceito de cidadania. Bendix amplia a análise de Marshall demonstrando a importância da educação para a integração social. Além disso, ambos entendem a conquista da igualdade de condição como um elemento fundamental para o desenvolvimento da noção de cidadania. Ajustando o foco para a análise do conceito de cidadania no Brasil, iniciamos pelas análises de José 
Murilo de Carvalho, Sérgio Buarque de Holanda e Roberto Schwartz para identificarmos o processo peculiar de construção da cidadania brasileira; em seguida, desenvolvemos nossa análise por meio de outros autores que exploraram a dificuldade de se forjar os ideais que compõem o conceito de cidadania em uma sociedade extremamente desigual. Os dados da pesquisa que vão dialogar com a teoria apresentada são os seguintes: “o que é ser cidadão?”, "cite exemplos de direitos", “cite exemplo de deveres", "você vota?", "pretende tirar o título de eleitor antes de completar 18 anos?", “Qual sua opinião sobre o voto?”.

No quarto capítulo, o conceito a ser analisado é o de cultura cívica. Os clássicos que nos apoiarão nessa abordagem serão Alexis de Tocqueville e Robert Putnam. O primeiro observa a democracia nascente na América do Norte e identifica o valor fundamental das associações para esse contexto; o segundo aborda o conceito de capital social e desenvolve uma pesquisa sobre a relação da cultura cívica com o desenvolvimento social e econômico de algumas regiões da Itália. Ambos ajudam a construir o conceito de cultura cívica, o qual, ao ajustarmos o foco para contexto brasileiro, terá como base a teoria de Elisa Reis com o conceito de "familismo amoral", além de Luís Werneck Vianna e Maria Alice Resende de Carvalho com a perspectiva da "modernização pelo alto", e finalizamos com José Álvaro Moisés e a noção de "convivência contraditória" que se caracteriza pela nossa desconfiança no sistema político, ao mesmo tempo que reforçamos a importância no sistema democrático. Os dados da pesquisa que irão ilustrar esse conceito serão: "opinião sobre a democracia", “confiança nas instituições", "avaliação dos políticos", “critérios para escolha de candidatos", "tipo de participação" e "sentimento pelo país".

Apesar das restrições da pesquisa de campo, pôde ser feita a comparação com os dados apresentados na pesquisa anterior, quando algumas questões já analisadas permanecem, tais como confiança na família, na escola e na universidade, percepção sobre a democracia, principais medos e a definição sobre o que é ser jovem, e outras trazem aspectos novos, como a noção dos direitos e a influência da internet, sobretudo das redes sociais, na maneira de acessarem informações. De qualquer modo, fica o convite para entender um pouco mais do que pensa o jovem do ensino médio das escolas das redes pública e privada de três regiões da Cidade do Rio de Janeiro. Esperamos em futuro próximo voltar a fazer a pesquisa de campo para que possamos não só captar as reflexões desses jovens sobre as questões que mais lhes afligem, mas também sobre o que pensam acerca dos rumos da democracia no país. 


\subsection{Metodologia de pesquisa}

Para realização dessa pesquisa, utilizamos dois métodos consagrados nas Ciências Sociais: o quantitativo e o qualitativo. O método quantitativo foi realizado por meio da aplicação de questionário (ver anexo). Na primeira pesquisa, o questionário era composto por 40 questões, os temas foram agrupados do seguinte modo: "perfil do entrevistado", "Cultura Cívica e Valores", "Percepção de Cidadania", "Avaliação da Cultura Política" e "Temas Gerais". Para efeito da pesquisa atual, tendo em vista nossas hipóteses sobre as possíveis mudanças nas percepções dos jovens, atualizamos uma parte do questionário, inserindo novas questões. Contudo, não alteramos as demais questões para não inviabilizar nossa comparação dos dados. As questões que foram retiradas, por considerarmos obsoletas, correspondiam aos tópicos "preferências musicais" e "fontes de informação". As questões acrescentadas foram as seguintes: "frequência no uso da internet", "atividade nas redes sociais", "compartilhamento de notícias", "moraria em outro país", "motivo para morar em outro país" "qual país?", "carga horária das aulas de sociologia", "importância da sociologia" e "temas estudados nas aulas de sociologia". Essas novas perguntas tiveram como objetivo identificar possíveis razões para mudanças nas percepções, além disso, as questões sobre morar em outro país têm como objetivo reforçar o conjunto de perguntas sobre cultura cívica com o objetivo de identificar quais aspectos presentes em outros países chamam atenção dos jovens a ponto de motivá-los a deixar o Brasil.

Os dados obtidos por meio da aplicação dos questionários foram tabulados em SPSS e, em seguida foram extraídos gráficos e tabelas que possibilitaram a análise dos novos dados e a comparação com aqueles obtidos na primeira pesquisa. Os números referentes ao trabalho de campo da primeira pesquisa podem ser observados na tabela a seguir.

\begin{tabular}{|l|c|l|}
\hline \multicolumn{3}{|c|}{ Primeira pesquisa } \\
\hline \multicolumn{2}{|l|}{ Total de escolas: 24} \\
\hline \multicolumn{3}{|l|}{ Total de grupos focais: 14} \\
\hline \multicolumn{3}{|l|}{ Total de questionários:1120 } \\
\hline $\begin{array}{l}\text { Escolas } \\
\text { públicas }\end{array}$ & 7 & $30 \%$ \\
\hline $\begin{array}{l}\text { Escolas } \\
\text { particulares }\end{array}$ & 13 & $54 \%$ \\
\hline $\begin{array}{l}\text { Escolas } \\
\text { públicas de } \\
\text { excelência }\end{array}$ & 4 & $16 \%$ \\
\hline
\end{tabular}


Para a pesquisa atual, optamos por reduzir o escopo da pesquisa, visto que ela seria realizada como objeto de dissertação de mestrado. Os números propostos para a nova pesquisa foram os seguintes:

\begin{tabular}{|l|c|l|}
\hline \multicolumn{3}{|c|}{ Pesquisa atual (proposta) } \\
\hline \multicolumn{2}{|l|}{ Total de escolas: 12} \\
\hline \multicolumn{3}{|c|}{ Total de grupos focais: 6} \\
\hline \multicolumn{3}{|l|}{ Total de questionários:480 } \\
\hline $\begin{array}{l}\text { Escolas } \\
\text { públicas }\end{array}$ & 4 & $30 \%$ \\
\hline $\begin{array}{l}\text { Escolas } \\
\text { particulares }\end{array}$ & 6 & $54 \%$ \\
\hline $\begin{array}{l}\text { Escolas } \\
\text { públicas de } \\
\text { excelência }\end{array}$ & 2 & $16 \%$ \\
\hline
\end{tabular}

Apesar da redução mantivemos a proporcionalidade do número de questionários dividido por tipo de escola. Esta manutenção da proporcionalidade nos garante a validade estatística para a comparação dos dados. Em números absolutos, temos que a quantidade de escolas pesquisadas será 12 (doze). Em cada escola deverão ser aplicados 40 (quarenta) questionários, totalizando uma amostra de 480 (quatrocentos e oitenta). A proporção por tipo de escola ficou ajustada da seguinte maneira: serão aplicados questionários em 4 (quatro) escolas públicas, 6 (seis) em escolas privadas e 2 (dois) em escolas públicas de excelência. Com relação à obtenção dos dados qualitativos, estabelecemos que serão realizados 2 (dois) grupos focais em escolas públicas, 1 (um) em escola pública de excelência e 2 (dois) em escolas particulares. Nesse momento, cabe ressaltar, que as escolas particulares escolhidas pela pesquisa se caracterizam por ser de alto padrão social e que possuem um valor médio de mensalidade (para o ensino médio) de 4 salários mínimos.

Após o encerramento das atividades de campo, devido à pandemia de Covid-19, tivemos que avaliar se os dados obtidos até aquele momento e vimos que ainda nos habilitavam a realizar a comparação com a pesquisa anterior. O total de dados coletados até aquele momento pode ser observado na tabela abaixo. 


\begin{tabular}{|l|c|l|}
\hline \multicolumn{2}{|l|}{ Pes quisa atual (consolidada) } \\
\hline \multicolumn{2}{|l|}{ Total de escolas: 9} \\
\hline \multicolumn{2}{|l|}{ Total de grupos focais: 2} \\
\hline \multicolumn{2}{|l|}{ Total de questionários: 250} \\
\hline $\begin{array}{l}\text { Escolas } \\
\text { públicas }\end{array}$ & 4 & $30 \%$ \\
\hline $\begin{array}{l}\text { Escolas } \\
\text { particulares }\end{array}$ & 5 & $45 \%$ \\
\hline $\begin{array}{l}\text { Escolas } \\
\text { públicas de } \\
\text { excelência }\end{array}$ & 0 & 0 \\
\hline
\end{tabular}

Ao observarmos que havíamos alcançado $75 \%$ da parte quantitativa, avaliamos que a comparação com os dados da pesquisa anterior poderia ser realizada sem prejuízos, contudo, não conseguimos os dados das escolas públicas de excelência, por isso, nossa pesquisa se concentrou na comparação entre os dados das escolas públicas estaduais e escolas privadas $^{2}$.

A aplicação dos questionários acontece dentro da sala de aula e a escola faz a intermediação com o professor que, eventualmente, terá que ceder um tempo de aula para essa atividade. O tempo de preenchimento dos questionários é de aproximadamente 40 minutos e, na maioria dos casos, os alunos demonstram entusiasmo em responder.

No momento da aplicação dos questionários alguns cuidados são tomados e é importante pontuá-los aqui. O primeiro cuidado é a observação do "clima da turma" que é disponibilizada pela direção (ou em alguns casos, pela coordenação pedagógica) da escola. Para esclarecer melhor essa questão citaremos três exemplos. O primeiro é de uma escola pública da Zona Sul. Ao chegarmos na escola ${ }^{3}$ para realizar a aplicação do questionário, o diretor nos informou que a turma de $2^{\circ}$ ano disponível para participar, era uma turma de alunos que estavam terminando de fazer uma prova de recuperação de física. Ao entramos na sala para aguardar a autorização para aplicação dos questionários, observamos que os alunos estavam cansados e aflitos para irem para casa. A observação desse "clima" nada satisfatório para aplicação dos questionários nos levou a pedir ao diretor que nos autorizasse a aplicação em outra turma ou o nosso retorno em um dia mais tranquilo, e a direção optou por essa segunda opção, remarcando a aplicação do questionário para a semana seguinte.

\footnotetext{
2 A lista das escolas que participaram da pesquisa está no Anexo II.

3 A aplicação do questionário nessa escola foi previamente marcada mediante contato telefônico com o diretor da escola.
} 
Outro exemplo aconteceu em uma escola pública na Tijuca ${ }^{4}$. Quando os alunos da rede estadual chegam no turno da manhã para a aula, geralmente, recebem um pequeno lanche composto por biscoito, uma bebida e uma fruta. No dia que estivemos nessa escola para aplicação do questionário, a escola ainda não havia recebido a entrega dos lanches e os alunos foram direcionados para a sala de aula sem o café da manhã. Ao entrar na sala indicada pela direção para aplicar os questionários, os alunos reclamavam bastante e estavam agitados, mesmo depois que conseguimos a atenção deles e explicamos o propósito da pesquisa eles ainda falavam sobre a ausência do café da manhã. Ao conversarmos com a diretora ela explicou que o lanche só chegaria por volta das dez da manhã. Diante desse cenário, compramos oito caixas de bombons no mercadinho que fica bem em frente à escola e dividimos entre os alunos que estavam respondendo o questionário. $\mathrm{O}$ clima da turma melhorou de modo tão positivo que ao final da aplicação dos questionários eles queriam saber mais sobre a pesquisa e se voltaríamos outro dia. O terceiro, e último, exemplo também é de uma escola pública ${ }^{5}$, nesse caso em Copacabana. Ao chegarmos à escola, a previsão indicava chuva e assim que começamos a explicar sobre a pesquisa, ouvimos uma série de trovões. Imediatamente os alunos ficaram agitados, visto que muitos moram em favelas cujo acesso em dias de chuva é prejudicado, além disso, o trânsito na região sempre fica (ainda mais) engarrafado e a direção tem por costume, liberar os alunos em dias com essa característica. Ao observarmos que a o clima da turma não era propício para a aplicação do questionário, solicitamos a direção que nos permitisse o retorno em outro dia. Diante do exposto, observamos que a observação sobre o "clima da turma" é de extrema importância para que os jovens respondam às questões com tranquilidade. Outro cuidado importante na aplicação dos questionários é com relação à informação de que a pesquisa não é uma avaliação. Geralmente os alunos, diante do questionário, tendem a associá-lo a uma prova, por isso, em todas as escolas, logo após a apresentação da pesquisa, enfatizávamos que o objetivo do questionário é a opinião deles e que não tem resposta certa ou errada.

Os dados qualitativos são obtidos por meio de grupos focais. A dinâmica consiste em realizar uma espécie de "roda de conversa". Nesta atividade apenas uma parte dos jovens que respondeu o questionário, são escolhidos (de modo aleatório) para participar. O único prérequisito é que os alunos escolhidos tenham respondido o questionário. A quantidade de

\footnotetext{
4 A aplicação do questionário nessa escola não foi previamente marcada porque os telefones do colégio não estavam funcionando e não obtivemos respostas dos e-mails que enviamos. Para conseguir aplicar esses questionários, aproveitei o contato de uma amiga que ministra aulas de artes nessa escola e consegui falar pessoalmente com a diretora que me autorizou a aplicação dos questionários no mesmo dia.

5 A aplicação de questionários nessa escola foi agendada depois de duas reuniões presenciais com o diretor, na primeira reunião, e com o diretor e a diretora adjunta na segunda reunião.
} 
alunos segue a uma quantidade que oscila entre 8 e 12 alunos. Seguindo o roteiro previamente elaborado $^{6}$ começamos a conversa com os jovens. Assim como na aplicação dos questionários, aqui também tomamos alguns cuidados. $\mathrm{O}$ cuidado principal é com relação ao anonimato das falas. Deixamos claro, antes mesmo de começarmos o grupo focal, que todas as falas eram anônimas e nem mesmo o nome da escola era apontado. O segundo cuidado é com relação à dinâmica da gravação: orientamos os jovens a falarem um de cada vez para que as vozes não se sobrepusessem na gravação. Outro cuidado é com relação aos assuntos abordados: apesar de nos guiarmos por um roteiro prévio, procuramos deixar os jovens bem à vontade para que pudessem falar e expor suas opiniões de maneira livre. A dinâmica do grupo focal tem uma duração média de 50 minutos. Todo material (gravação e anotações) adquirido durante os grupos focais foi transcrito e compõe o banco de dados da pesquisa.

\footnotetext{
6 Anexo II
} 


\section{2 \\ Juventude: a construção social de um conceito no plural}

Os séculos XVIII e XIX são os séculos das grandes transformações socioculturais. A contestação dos sistemas políticos vigentes e os avanços técnico-científicos reformularam toda a organização social ocidental. Diante desse cenário, surge a necessidade de se compreenderem os fenômenos sociais de sociedades cada vez mais complexas e é nesse contexto que surge a Sociologia. De acordo com Giddens (1984):

\footnotetext{
"O desenvolvimento da Sociologia, assim como suas preocupações atuais, tem de ser apreendido no contexto das mudanças que criaram o mundo moderno (...) No decorrer de apenas dois séculos, tiveram lugar avassaladoras mudanças sociais que, nos dias de hoje são ainda mais aceleradas. Tais mudanças, que se originaram na Europa Ocidental, fazem-se sentir agora por toda parte. Elas dissolveram totalmente as formas de organização social em que a humanidade viveu durante milhares de anos" (p.11)
}

A Sociologia se impõe enquanto campo do conhecimento científico e autônomo, capaz de compreender e explicar os fenômenos, daí em diante, denominado de sociais. Nesse contexto de modernidade e surgimento da Sociologia, a juventude se tornará objeto de estudo dessa ciência e, conforme verificaremos adiante, se tornará uma categoria social responsável pelo desenvolvimento de um repertório conceitual e metodológico.

Neste capítulo, nossa proposta assume a preocupação em demonstrar de que modo a Sociologia e o conceito de juventude desenvolvem-se em profunda interação e procura destacar a importância do desenvolvimento do método sociológico para a validação da juventude como objeto de estudo. Para tanto, nosso ponto de partida, terá como base os autores fundadores da Sociologia, são eles: Karl Marx e Émile Durkheim.

As análises de Marx acerca do modo de produção capitalista decorrem justamente do ambiente no qual estava inserido: a Revolução Industrial, no século XIX, na Inglaterra. Diante disso, seu o olhar atento procurará entender as causas e fornecer possíveis soluções para as desigualdades que se desenvolvem nesse período.

Importante dizer que, embora não tenha se detido na observação específica sobre a temática da juventude, seu exame sobre as condições dos jovens operários serve de contribuição para seguirmos as pistas que nos levam ao caminho percorrido na construção desse conceito no âmbito das Ciências Sociais.

Em texto intitulado Trabalho, juventude e educação politécnica, Marx revela nítida preocupação com os jovens operários de seu tempo. Construindo a teoria sobre a divisão social de classes, enxerga nos jovens da classe operária uma força potencial de mudança 
social, desde que tivessem acesso a uma formação politécnica, isto é, uma formação voltada para o desenvolvimento mental, corporal e para o trabalho.

Essas ideias foram por ele apresentadas no Primeiro Congresso Internacional dos Trabalhadores, em 1866, nessa ocasião, Marx expôs suas preocupações sobre a condição de exploração do proletariado juvenil. Num primeiro momento, o autor, acredita que, para minimizar os efeitos da exploração, seriam necessárias medidas legais impostas pelo Estado, por exemplo, a proibição do trabalho noturno para os jovens. Além disso, defende que crianças e adolescentes possam exercer atividades laborais, contanto que o trabalho desenvolvido esteja compreendido em um plano de educação, o que exigiria aplicação educacional mental, física e técnica gradativa, de acordo com a faixa etária de cada um deles. Para Marx, a infância e a juventude devem ser divididas em três fases: a primeira de 9 a 12 anos, a segunda de 13 a 15 e a terceira de 16 a 17 anos. A preocupação em realizar essa divisão etária em fases era determinar o tempo máximo (diário) de trabalho.

A educação aparece como condição fundamental para a formação da juventude operária, destacando que:

“(...) a parte mais esclarecida da classe operária compreende perfeitamente que o futuro de sua classe e, por consequência, da espécie humana depende da formação da geração da classe operária que cresce (...) A sociedade não pode permitir, nem aos pais, nem aos patrões empregarem para o trabalho as crianças e os adolescentes, a menos que este trabalho produtivo seja combinado à educação" (Marx, 1963.p. 17)

Com base no exposto, observamos que, para Marx, a situação de exploração em que estavam sujeitos os operários do século XIX também atingia os jovens e as crianças, os quais necessitavam que a sociedade se responsabilizasse e tomasse medidas visando sua educação e condições mínimas de proteção. Segundo ele, "Essa combinação do trabalho produtivo pago com a educação mental, com exercícios corporais e com a aprendizagem politécnica, elevará a juventude operária a um nível bem superior ao da classe burguesa e aristocrática” (Ibid., p. 18).

Deste modo, Marx nos ajuda a identificar que a juventude, já no século XIX, está marcada por certa polissemia, visto que existem, pelo menos, duas condições de juventude nesse contexto: a diferença entre a juventude burguesa, com condições mais abastadas, e a juventude operária. De um lado, encontra-se a juventude burguesa e a aristocrática, com acesso ao tempo livre e à educação formal com vista à preparação para uma vida adulta e, do outro, encontra-se o jovem operário, vítima direta da exploração e sem acesso às condições mínimas de dignidade e de expectativa de mudança. 
Reforçamos aqui que Marx não realizou uma análise específica sobre a juventude, mas sua perspicácia sensível à questão do sistema de classes, não deixou passar desapercebido o prejuízo que a desigualdade poderia causar ao jovem operário.

Outro fundador da Sociologia, Émile Durkheim, também perceberá a juventude como uma etapa da vida que merece uma atenção diferenciada. O contexto que Durkheim observa é diferente do de Marx. No geral, a Europa de Durkheim gozava de relativa paz e, sob o aspecto econômico, estava no auge da industrialização. Especificamente, sua obra é escrita no período que marca a passagem do século XIX para o XX e, ao contrário de Marx, não vivencia o clímax das turbulentas revoluções operárias. Poderíamos dizer até que experimentou um período de "bonança", tendo em vista a sedimentação das bases da ordem social burguesa, além disso, seu foco de atenção estava nas formas de integração social das sociedades ocidentais que se tornavam cada vez mais complexas.

Durkheim entende a juventude como uma espécie de "tábula rasa" sobre a qual as gerações mais velhas, por meio da família e da escola, em um movimento vertical e de cima para baixo, irão inculcar todas as normas sociais. Sendo assim, a juventude seria essencialmente um período de preparação do indivíduo para as regras estabelecidas pela sociedade.

O jovem para Durkheim seria um indivíduo em formação, sem autonomia, um receptáculo de normas e regras sociais. A formação desse jovem seria condição fundamental para a manutenção da sociedade. Segundo ele, "a sociedade encontra o meio pelo qual ela prepara, no íntimo das crianças, adolescentes e jovens, as condições essenciais da própria existência" (Durkheim, 1978, p. 41). Nesse sentido, Durkheim vê na juventude as condições de permanência e manutenção da própria sociedade, por isso, a necessidade dos locais de sociabilidade como, por exemplo, a escola ou a família, onde as crianças e adolescentes teriam condições de receber e aprender os modelos e os padrões estabelecidos pela ordem social vigente.

Importante destacar que a perspectiva sobre juventude para Durkheim e Marx são diferentes. O primeiro faz sua abordagem à luz da perspectiva funcionalista e, por isso, identifica o jovem como receptáculo de normas sociais que deverão ser reproduzidas para manutenção da coesão social. Marx, por outro lado, sob a luz da perspectiva crítica, identifica a juventude como a vítima mais vulnerável da exploração capitalista, mas com grande potencial para transformar essa realidade. Embora esses dois autores vejam a escola/educação formal com um papel importante para a juventude, cada um atribuirá uma função para ela. Marx vê na escola técnica a possibilidade de "emancipação" do jovem, 
enquanto Durkheim propõe uma educação para a promoção de valores que levem à coesão social. Podemos dizer que Durkheim, com seu esforço de construção de um método para as Ciências Sociais, inaugura a perspectiva da juventude como categoria de análise.

Esse primeiro "olhar" dos autores clássicos da sociologia para os jovens marca o início da construção da juventude como objeto de estudo das Ciências Sociais, ao passo que, um campo de discussão se amplia e outras ciências, tais como a psicologia, biologia, a história, passam a aportar análises para essa discussão.

Em 1904 o psicólogo norte americano G. Stanley Hall em sua obra “Adolescence: lts Psychology, and its Relations to Physiology, Anthropology, Sociology, Sex, Crime, Religion and Education" entendeu o período da adolescência como uma fase natural e universal. Natural porque é fisiológica e universal porque seria uma fase de desenvolvimento humano que se encontraria em todas as sociedades e em diferentes momentos históricos, por esse motivo ele usa o termo adolescência. Influenciado pelo darwinismo, Hall estabeleceu que essa fase se determinaria pela idade e que seria dos 12 aos 22-25 anos. Segundo ele essa fase seria caracterizada pelo instinto e pela força e para que os jovens tivessem tempo para se enquadrarem nos padrões de comportamento dos adultos (estando num estágio intermediário entre a selvageria e a civilização). Essa posição da psicologia foi duramente criticada, sobretudo pela antropologia por não levar em consideração os aspectos culturais.

Quando Margaret Mead iniciou seu trabalho de campo em Samoa, em 1925, essa perspectiva da psicologia sobre juventude estava muito em voga entre os educadores norteamericanos. Contudo, a partir dos estudos de Mead (Coming of age in Samoa, 1928) as ideias de Hall puderam ser confrontadas. Ao defender que a adolescência era uma fase de crise e de passagem, o psicólogo fez uma generalização a partir dos jovens norte-americanos. Ao analisar os jovens de Samoa, Mead explica que para os jovens dessa sociedade esse período da vida não é marcado por uma crise nem mesmo pela instabilidade, ao contrário, trata-se de um período de desenvolvimento harmônico por meio de atividades que proporcionam o amadurecimento. Desse modo, a autora ao relativizar o conceito de juventude, inaugura a abordagem antropológica do tema.

A partir dessa perspectiva, constrói-se a noção de que cada sociedade organiza a transição da infância para a vida adulta e que esse modo de organização vai além da diretriz biológica. Ainda que esse processo de transição tenha uma base biológica inegável, não é toda sociedade que define essa mudança a partir de uma marcação física. Sendo assim, há uma diferenciação definitiva entre o conceito biológico de adolescência e o conceito de juventude como grupo social a ser analisado. 
A partir do século XX, os debates sobre juventude e os diferentes campos de estudo se mobilizam de modo tão dinâmico que Ariès (1981) define esse século como "O século da juventude". Além disso, o aumento da população urbana (êxodo rural e as imigrações), a ausência de infraestrutura das cidades e pouca oferta de trabalho, geram desigualdades que levam os jovens a se posicionarem por meio de comportamentos mais "agressivos" que eram vistos como violentos e desviantes. Para os adultos esses comportamentos indicavam desrespeito às normas e intransigência. Contudo, Morin (2002) analisa essa situação (de transgressão dos jovens) como uma perda do protagonismo dos adultos, o que denomina como processo de "degerontocratização", segundo o autor:

\footnotetext{
"No grupo arcaico, a velhice detém a autoridade da sabedoria; a passagem do estado adulto se realiza segundo os ritos que asseguravam uma verdadeira morte da infância e o nascimento da virilidade. Com o desenvolvimento das civilizações, a autoridade dos velhos se degrada (...) a experiência dos idosos se torna lengalenga desusada, anacronismo. A "sabedoria dos velhos" se transforma em disparate. Não há mais sabedoria. O conjunto da sociedade foi arrastado por um movimento de degerontocratização" (p. 147)
}

Nesse contexto de degerontocratização surgem grupos formados exclusivamente por jovens que pretendiam abrir um espaço para construção de suas identidades e reinvindicações e com isso, se distanciavam das normas estabelecidas pelos adultos, tais como os Hooligans na Inglaterra, os Apaches na França e os Wandervogel que surgiram na Alemanha e se espalharam para Áustria e Suíça (Savage, 2009). É justamente essa movimentação dos jovens urbanos em grupos de afinidades que chamará a atenção dos estudiosos interessados em entender as motivações e os possíveis perigos dessa juventude.

Usando metodologias de pesquisa diversas a Escola de Chicago irá se destacar pelo 'modelo ecológico', desse modo os grupos juvenis são observados como resultado do processo de urbanização e com enfoque na classe social. Inicialmente os resultados das pesquisas quantitativas atrelavam a juventude pobre e urbana às situações de crime, baderna e desvio. Essas pesquisas incentivam William Foote Whyte a realizar uma observação participante com jovens pobres, imigrantes, filhos de italianos que formavam gangues em Boston na década de 1930. Após um longo estudo que deu origem ao livro "Sociedade de esquina" o autor refuta a tese de que a juventude urbana era sinônimo de desorganização e anomia e identifica que, por traz do comportamento "transviado" daqueles jovens, havia uma postura de questionamento sobre a falta de oportunidades e a desigualdade na qual estavam submersos. Desse modo, o jovem urbano ganha centralidade nas discussões e estudos das Ciências Sociais. 
Nos anos 1950 a juventude ganha uma configuração especial composta por uma série de especificidades, tais como o estilo de roupa, o tipo de lazer, o gosto musical, a forma de falar, dentre outros elementos que marcam um "perfil" juvenil em oposição ao mundo adulto. Surge assim, uma indústria do jovem, a indústria teen que reforça uma "cara" da juventude por meio de objetos de consumo. Essa construção tem relação como o período do Pós Segunda Guerra mundial e a necessidade de construir um clima mais alegre, despojado e estimular o consumo depois de tantos anos de guerra, sobretudo na Europa e nos EUA. Eram os chamados "Anos Gloriosos" marcados pelos teddys boys e pelo rock'in roll, surge nesse contexto a ideia de uma cultura juvenil amplamente divulgada pela indústria cultural. (Savage, 2009).

Nesse contexto destacam-se os estudos do Centre for Contemporary Cultural Studies de Birminghan (CCCS). Enquanto a ideia de cultura juvenil apresenta um jovem movido pelo consumo hedonista e supérfluo, estudiosos como, Paul Willis, Phil Cohen e Stuart Hall, irão se dedicar ao estudo das subculturas juvenis e vão propor uma interpretação dessa relação dos jovens com o consumo mediada pelo conceito de classes sociais. Embora a emergência de nossos estilos juvenis vinculados ao consumo fosse inegável, o que eles buscavam eram as motivações mais profundas para esses novos estilos juvenis, os quais serão denominados de subculturas juvenis. Os resultados das pesquisas apontavam para uma atitude "geracional e funcional", ou seja, o jovem pobre da classe operária usava os objetos de consumo (roupas, músicas, penteados) como uma forma de afirmar sua identidade diferente da dos seus pais, além da resistência à cultura dominante que tendia a homogeneizar e neutralizar as diferenças.

A partir desse momento, os estudos sobre a juventude ganham uma perspectiva mais plural e surgirão novas categorias de análises que somarão interpretação à dimensão cultural, como por exemplo as análises de Stuart Hall, John Clarke, Tony Jefferson e Brian Roberts apresentadas no livro "Resistance through Rituals: Youth subcultures in post-war Britain" (1976), no qual apresentam as categorias, mods e skins (formados por jovens das classes operárias), freaks e Hippies (vinculados às classes médias).

A década de 60 foi especialmente importante para a juventude, pois nela há uma “explosão” de sua participação na esfera pública, em outras palavras, podemos dizer que há uma evidência do jovem como ator social, quando vários deles se engajam nos movimentos ecológico, pacifistas, feministas, além dos movimentos pelos direitos civis, no leste europeu, nos EUA ou contra a colonização nos países africanos. Um sociólogo que traz juventude como categoria essencial de análise nos movimentos sociais a partir dessa época é Alain 
Touraine (2009), que chama atenção para o "novo ator" que surgirá a partir da consciência de suas carências e que é levado ao engajamento político a partir de uma motivação que não, necessariamente, tem origem nas relações de classe, sindicais ou partidárias, mas que se forma a partir da sua percepção da vida em sociedade, ou seja, a partir de sua experiência. Outro conceito importante sobre a juventude elaborado nessa mesma década pelo sociólogo J. Milton Yinger é o de contracultura. Embora já tivesse sido usado anteriormente por Talcolt Parson em seu livro TheSocial System é Yinger que dará a esse conceito a definição de um comportamento relacionado aos valores identitários de um grupo jovem com intuito de se posicionar social e politicamente contra a cultura dominante.

Analisamos até aqui a construção do jovem como objeto de estudo das Ciências Sociais do "primeiro olhar" dos clássicos, até sua configuração por meio de três conceitos: “cultura juvenil", "subculturas juvenis" e "contracultura". Não cabe aqui, para efeito desse trabalho, nos aprofundarmos mais nesses conceitos, nosso intuito é demonstrar, de maneira sucinta, como o conceito de juventude foi sendo desenvolvido a partir de um repertório epistemológico, teórico e metodológico, por isso, nesse momento, apresentaremos dois autores que servirão de base fundamental para os estudos sobre juventude.

Um marco fundamental para o estudo da juventude será produzido por Karl Mannheim por meio de sua obra que definirá um campo de estudo específico: a Sociologia da Juventude a partir de suas reflexões sobre fatos culturais e da sociologia do conhecimento. Em sua obra "o problema das gerações", o autor se afasta da teoria de classes e observa dois enfoques diferentes sobre o tema. De um lado os positivistas franceses e de outro os "histórico-romancistas" alemães. Para os positivistas a análise das gerações é feita a partir da metodologia quantitativa e segue uma perspectiva biológica e linear. Para essa concepção haveria uma "unidade geracional" que seguiria uma linearidade histórica segundo a qual cada geração corresponderia ao tempo de trinta anos. Por se pautar nessa concepção linearhistórica, essa corrente entende a juventude (sempre) como um momento de transição essencialmente tempestuoso para a vida adulta. Mannheim mostra preferência pela vertente alemã e formula a ideia de tempo de experiência interna detectável (erfassbarer innerer erlebniszeit) para ele a geração não é simplesmente cronológica e mecanicista, mas algo muito mais profundo que tem relação com a similaridade de influências simultâneas ou contemporâneas (Gleichzeitigkeit). Desta forma, para estudar gerações, aconselha Mannheim, devemos observar tanto as estruturas relacionadas às conjunturas histórica, política e social, quanto as estruturas relacionadas a experiências dos atores nos espaços sociais. Diante dessa abordagem de Mannheim sobre as gerações foi inaugurado um campo 
teórico-metodológico mais amplo e que considera um repertório cada vez mais abrangente de metodologias.

Esse campo teórico-metodológico mais amplo, que ao invés de enfocar somente numa perspectiva quantitativa ou qualitativa, se abre para a junção dos métodos, além da consideração sobre a experiência dos sujeitos fica claro no texto "O problema da juventude na sociedade moderna". Ali Mannheim começa com duas perguntas "O que a juventude pode nos dar?" e "o que a juventude pode esperar de nós?” (p.69). Ao se ater à primeira pergunta o autor aponta pistas para a análise sociológica sobre a juventude. Em suas palavras:

\begin{abstract}
"O primeiro problema que nos fere é esse: será sempre o mesmo o significado da juventude na sociedade? Evidentemente, não. Há sociedade em que pessoas mais velhas desfrutam prestígio bem maior que as moças, como, por exemplo na antiga China. Há outras em que, como nos Estados Unidos da América, depois dos 40 anos muitas vezes um homem é considerado velho demais para um emprego e só os moços se interessam" (p.71)
\end{abstract}

Depois de exemplificar interpretações da juventude em diferentes contextos sociais, o sociólogo expõe que o "problema da juventude" está na função que cada sociedade confere a esse grupo, por isso a necessidade da contextualização desse conceito. De acordo com ele: "o problema sociológico é que, apesar de sempre surgirem novas gerações em função dos grupos de idade menor, depende da natureza de uma sociedade esta fazer ou não uso delas, e depende da estrutura sociológica dessa mesma sociedade o modo pelo qual ela as utiliza” (p.71).

De acordo com Mannheim no contexto das sociedades modernas é possível observar uma confiança maior em mobilizar os recursos latentes ${ }^{7}$ (juventude) em prol das mudanças necessárias para revitalizar a sociedade. Para o sociólogo isso ocorre devido a dois fatores. $\mathrm{O}$ primeiro diz respeito à própria estrutura das sociedades modernas que, ao contrário das sociedades tradicionais, produzem maior dinamismo nas relações sociais e estão abertas para mudanças; O segundo diz respeito à relação entre a juventude e o status quo.

Essa relação dos jovens com o status quo caracteriza-se pelo que Mannheim chama de "homem marginal" isso porque os jovens ainda não têm nenhum "apego" à estrutura econômica e desta forma, é mais fácil para esses pensar em rupturas ou transformações.

\footnotetext{
"Na linguagem da Sociologia, ser jovem significa sobretudo ser um homem marginal, em muitos aspectos um estranho ao grupo. Com efeito, o fato mais notável sobre a atitude dos alunos das últimas séries do ensino médio e dos universitários é eles ainda não terem interesses adquiridos na ordem social existente e não terem integrado sua contribuição à tessitura psicológica e econômica da sociedade construída (...) logo que se instalam num emprego e
}

\footnotetext{
${ }^{7}$ Mannheim explica que a juventude "pertence aos recursos latentes de que toda sociedade dispõe" (p.71) e usa esse termo "recursos latentes" para falar da juventude em boa parte do texto.
} 
constituem família, passam a defensiva e intercedem em favor do status quo (p.75)"'.

Essa situação "livre" do jovem com relação ao status quo o coloca na condição de potencialidade transformadora da sociedade.

A partir dessa análise, Mannheim ilumina a compreensão sobre o estudo da juventude na perspectiva sociológica mostrando que "devemos considerar o contexto, a relação da sociedade para com a juventude (mobilização ou supressão) e a relação do jovem para com o status quo (p.75).

Essa perspectiva que critica uma imagem generalista da juventude e que enfatiza a necessidade de contextualização será, também, defendida por Bourdieu. Segundo o autor: “o que eu quero lembrar é simplesmente que a juventude e a velhice não são dadas, mas construídas socialmente, na luta entre os jovens e os velhos." (BOURDIEU, 1983, p.152). Com essa afirmação o autor expõe duas situações com relação ao estudo sobre juventude, a simplificação de algumas abordagens que se concentram em apenas um dos aspectos da juventude e as relações de poder que envolvem o tema. As abordagens que se concentram em apenas um aspecto da juventude, na visão de Bourdieu, são feitas com a intenção de manipular a construção da juventude. Em suas palavras: “O fato de falar de jovens como se fossem uma unidade social, um grupo constituído, dotado de interesses comuns, $e$ relacionar estes interesses a uma idade definida biologicamente já constitui manipulação evidente” (p.153). Desta forma, Bourdieu desconstrói a ideia de juventude como uma "massa homogênea" ao demonstrar sua condição de construção social.

A partir desse ponto, seguindo as orientações dadas por Mannheim e Bourdieu, vamos ajustar o foco de nossa análise para demonstrar sobre qual juventude estamos nos debruçando nesse trabalho. Inicialmente demonstraremos os primeiros estudos sobre juventude no Brasil, faremos uma breve análise sobre os principais conceitos e, em seguida, vamos apresentar os jovens que são o foco deste trabalho, incluindo, nesse esforço uma análise sobre a realidade do locus no qual estão inseridos, ou seja, faremos também uma breve apresentação sobre a realidade da escola pública e particular no Rio de Janeiro. 


\section{1}

\section{A construção do conceito de juventude na sociologia brasileira}

Menos do que uma etapa cronológica da vida, menos do que uma potencialidade rebelde e inconformada, a juventude sintetiza uma forma possível de pronunciar-se diante do processo histórico e de constituí-lo. FORACCHI, 1965, p. 303

Como vimos até aqui, juventude não é apenas uma condição definida pelo fator etário, mas sim pelas condições sociais. No Brasil o tema da juventude chega para as Ciências Sociais com toda carga referencial dos estudos realizados em outros países, sobretudo dos Estados Unidos e França.

Um dos primeiros estudos realizados sobre essa temática no Brasil foram os realizados por Otávio Ianni e Marialice Foracchi. Influenciada pelo pensamento de Karl Mannheim, Foracchi vai iniciar os estudos sobre juventude no campo educacional a partir das teorias do conhecimento e do planejamento. Para ela a juventude pode ser definida a partir de três eixos de compreensão: a) se trata de uma fase da vida, b) possui capacidade de ser força renovadora e transformadora, c) é muito mais que uma fase cronológica. Contudo, a autora não deixa de identificar a existência de diferentes experiências juvenis. Para ela os diferentes estratos sociais produzem diferentes "maneiras de ser" impostas aos jovens. Essas condições impostas são geradas pela situação de classe.

Uma das primeiras pesquisas realizadas sobre juventude no Brasil foi a que deu origem a tese de Foracchi na Universidade de São Paulo (USP) resultando na publicação: “O Estudante Universitário: resultados iniciais de uma investigação sociológica"8(1962). Preocupada em responder à questão de Mannheim sobre quais são as condições que tornam determinados membros de uma geração conscientes de sua situação e a partir disso geram elementos para a formação de um grupo concreto, como o próprio movimento estudantil, a autora desenvolverá mais dois textos importantes: "O estudante e a transformação da sociedade brasileira"(1965) e "A juventude na sociedade moderna" (1972).

Sua metodologia parte da abordagem dialética influenciada, por Karl Mannheim e da compreensão analítica da estrutura e da ação social sob influência de Florestan Fernandes. Deste modo, a autora encontrou uma correlação entre o movimento estudantil universitário

\footnotetext{
${ }^{8}$ Esta pesquisa teve início em 1960 e foi dividida em três parte. A primeira parte foi realizada mediante aplicação de questionários em 377 estudantes universitários. A segunda etapa consistiu na sistematização dos dados e na definição de categorias empíricas compostas pelos estudantes. Foram elas: a) estudantes totalmente mantidos pela família, b) os parcialmente mantidos pela família e c) os estudantes que trabalhavam, além disso, foram realizadas entrevistas abertas com 55 estudantes que haviam respondido o questionário. A entrevista foi realizada com base m roteiro previamente elaborado. A terceira e última etapa da pesquisa foi a realização de entrevistas com líderes estudantis da época. não precisa tantos detalhes
} 
e classe social por meio da distinção entre as categorias jovem e estudante. De acordo com a autora:

\begin{abstract}
Uma das principais tarefas com que se depara a abordagem sociológica é, pois, caracterizar o conjunto de mecanismos e processos que presidem à constituição do estudante como categoria social. Isso significa que o estudante deve ser focalizado tanto em termos das condições sociais que balizam o seu comportamento, vinculado a ordem social existente; quanto em termos das modalidades possíveis de ampliação dos seus horizontes de ação $(1965$, p.3)
\end{abstract}

A definição da categoria "estudante" e a análise da práxis estudantil são feitos de Foracchi e se tornaram essenciais para a construção da teoria social sobre juventude no Brasil.

O estudante seria o jovem que está vinculado a um sistema social elaborado pelos adultos. Esse sistema social exerce influência nesse jovem por meio das instituições (principalmente a família e a escola). Deste modo, a categoria social "estudante" é construída por meio de três situações: a) as relações interpessoais, b) a situação de classe e c) os processos de transformação da sociedade inclusiva.

a) As relações interpessoais dizem respeito à relação entre o jovem e sua família na denominada socialização primária. Como o jovem é um ser em formação, a família se torna a responsável por determinar as diretrizes que devem ser seguidas. Essas orientações servem para vincular o jovem ao sistema social e são realizadas dentro de uma lógica de manutenção e dependência.

b) As relações de classe representam objetivamente "os padrões de pensamento e de experiência inerentes ao estilo de convivência da sociedade moderna" (Foracchi, 1965, p.66 Apud. Augusto, 2005.p.13). Além disso, identificou a relação direta entre a noção de classe e a ação dos jovens engajados no movimento estudantil.

c) O último critério para a formação da categoria social do estudante diz respeito ao nível prático da "atuação estudantil-juvenil” (Augusto, 2005.p.16). As gerações anteriores esperam que o jovem se enquadre num comportamento esperado reproduzindo valores dessa geração e transmitindo para a próxima geração. Nas palavras da autora: "as pressões modeladoras do adulto induzem o jovem a formar-se de acordo com os padrões e com a problemática pelo grupo incorporada pelo grupo com o qual o adulto se identifica" (Foracchi, 1965.p60,61. Apud. Augusto, 2005. P.17).

O esforço de Foracchi para construir a categoria "estudante" consiste em apontar o potencial de transformação do movimento estudantil evitando que suas ações sejam identificadas pelas gerações mais velhas como "mera rebelião ou uma turbulência natural aos que são jovens" (p.286). 
O contexto em que Foracchi analisa o estudante e o movimento estudantil universitário brasileiro começa nos primeiros anos da década de 1960 passando pelo período do golpe militar. A desigualdade social fica cada vez mais exposta com o aumento da migração e a urbanização sem planejamento (Fernandes, 1967). É nesse contexto que autora observa a força e as formas de ação do movimento estudantil, o qual sai de um radicalismo estruturado nas relações de classe e passa para uma atuação política mais engajada na luta pela democracia.

De modo geral Foracchi vai explicar a formação do movimento estudantil no Brasil, além de tratar da polissemia da noção de juventude, de identificar a coexistência de diferentes gerações e de categorizar o "estudante". Assim como Foracchi, Octavio Ianni também terá Manheinn como sua principal referência e observa os movimentos estudantis no contexto da década de 1960.

O autor fará um texto conciso sobre radicalismo e juventude que consiste em uma análise da particularidade da condição de juventude nas sociedades modernas. De acordo com ele: "A história do regime capitalista tem sido a história do advento da juventude. Em cada país em que se desenvolve o sistema capitalista de produção, os jovens assumem importância crescente no campo da ação política.” (1962, p.225). Desta forma, observamos que, para esse autor, “o jovem radical” é aquele que se encontra no mundo do trabalho e é esse ambiente que gerará as condições para a construção de um comportamento revolucionário, visto que "o capitalismo transforma de maneira tão drástica as condições de vida dos grupos humanos que a juventude se torna rapidamente um elemento decisivo dos movimentos sociais, em especial das correntes políticas de direita e de esquerda"(1962, p.225).

Por meio de uma análise fortemente marcada pela situação de classe social, Ianni irá formular o conceito de "jovem radical" que é aquele que não se enquadra ao status quo e questiona a sua condição, contudo a "sociedade capitalista não está em condições de eliminar as suas contradições internas, preservando-se” (p.232) colocando o jovem radical na condição de marginalidade e/ou imaturidade.

A obra de Ianni, por outro lado, nos ajuda a perceber que o atributo dado aos jovens como os responsáveis pelos movimentos de vanguarda também passa pela questão da pluralidade de juventudes. O que queremos dizer aqui ao definir o "jovem radical", Ianni deixa um "espaço" para que percebamos que nem todo jovem é "radical" e engajado em movimentos que questionam o "status quo", existe uma pluralidade de formas de engajamento, inclusive também é possível o não engajamento. 
Sobre esse aspecto do engajamento dos jovens, Novaes (2013) aponta uma série de movimentos apoiados e/ou organizados pelos jovens desde os anos 1920 começando pelo movimento tenentista, o movimento semana de Arte moderna e o movimento político partidário que deu origem ao PCB. Dos anos 1930 a meados de 1950 muitos movimentos contaram com o apoio sistemáticos dos jovens urbanos, tais como os movimentos classistas e os projetos unificadores da nacionalidade. Nesse mesmo período os jovens também protagonizam movimentos que deram origem a UNE (União Nacional dos Estudantes). Além disso, Angela Paiva explica que a Ação Católica também teve um papel fundamental na ampliação desse espaço de atuação dos jovens ${ }^{9}$. Para a pesquisadora, a AC ao desenvolver uma nova "consciência cristã sobre o momento histórico e uma reflexão sobre a realidade", produziu uma "mudança profunda no ethos religioso". A partir desse momento, a atuação da Juventude Universitária Católica (JUC) e da Juventude Estudantil Católica (JEC) saem do âmbito das reuniões e discussões filosóficas religiosas e ganham consciência sobre o momento histórico e a necessidade de irem de uma reflexão sobre a realidade para o engajamento na sociedade. Segundo Paiva (2003) "é, enfim, o momento em que a maior militância ia, inevitavelmente, levando a caminhos novos de participação política" (p.185).

A partir das transformações sociais e econômicas ocorridas na década de 1960 a participação da juventude em movimentos se expande. A atuação de grupos de jovens durante a década de 1960 no Brasil fez com que esses se tornassem uns dos principais alvos da opressão realizada pela ditadura militar que se instala a partir de 1964. De acordo com Novaes: "No novo cenário, nos anos de 1960, além de se conceberem como "intelligentsia", vanguarda cultural e política, os jovens foram desafiados a tomar posições no debate sobre diferentes caminhos da modernização e de desenvolvimento ${ }^{10}$ ".

Na década de 1970 o estudo "Os jovens e as mudanças estruturais na década de 70: questionando pressupostos e sugerindo pistas” de Felícia Reicher Madeira, analisou por meio de pesquisas com abordagem qualitativa ${ }^{11}$ e quantitativa ${ }^{12}$ a estrutura das condições de trabalho e educação de jovens com idade entre 15 a 24 anos. De acordo com a autora o objetivo da pesquisa foi: "demonstrar como essas parcelas da população foram

\footnotetext{
9 Novaes também ressalta a importância da atuação da JUC, JEC e demais setoriais tais como a JAC (Juventude Agrária Católica) e JOC (Juventude Operária Católica).

10 Sobre essa questão do desenvolvimento Novaes aponta que diferentes entendimentos sobre o desenvolvimento eram apresentados nessa época. De um lado a "Aliança para o progresso da CEPAL (Comissão econômica para América Latina e Caribe) e de outro lado a versão defendida pelos grupos de esquerda, sobretudo pelo Partido Comunista, trotskistas ou ligados à experiência da Revolução Cubana).

11 A pesquisadora realizou dezenas de entrevistas com diversos jovens das áreas periféricas da cidade de São Paulo e da Zona Rural

12 Nessa pesquisa Madeira mobilizou dados obtidos pelo Censo demográfico - IBGE (1970-80) pela PNAD (Pesquisa Nacional por Amostra de Domicílios) e da Unesco.
} 
condicionadas a participar das tendências do mercado de trabalho ocorridas ao longo desse período, contribuindo a sua maneira para novos contornos que assumiu a sociedade brasileira, e, em segundo lugar, como essas mudanças acionaram mecanismos de acesso pelos setores populares à identidade jovem”(p.3).

O estudo de Madeira (1984) abre espaço para que se identifique uma juventude que ainda não havia sido estudada de modo sistemático, ou seja, os jovens dos setores populares e da zona rural. Ao mobilizar dados que demonstram a situação de trabalho e educação dos jovens, a pesquisadora aponta para a dimensão da desigualdade que atinge essa parcela da população.

A tabela que será demonstrada a seguir, tem como fonte a Unesco e foi usada por Madeira para exibir a situação de desigualdade no acesso à educação da população jovem brasileira.

\begin{tabular}{|c|c|c|}
\hline \multicolumn{3}{|c|}{$\begin{array}{c}\text { Tabela } 15 \\
\text { América Latina (seis países): percentagem de } \\
\text { analfabetismo dos jovens de } 15 \text { a } 24 \text { anos, } 1980\end{array}$} \\
\hline PAÍSES & $\begin{array}{c}\text { TOTAL DE } \\
\text { ANALFABETOS }\end{array}$ & $\%$ \\
\hline $\begin{array}{l}\text { Argentina } \\
\text { Brasil } \\
\text { Chile } \\
\text { México } \\
\text { Panamá } \\
\text { Peru }\end{array}$ & $\begin{array}{r}85.559 \\
3.917 .520 \\
43.065 \\
905.091 \\
17.106 \\
217.524\end{array}$ & $\begin{array}{r}1,9 \\
15,7 \\
1,8 \\
6,5 \\
4,7 \\
6,3\end{array}$ \\
\hline
\end{tabular}

A análise da tabela nos permite identificar que o Brasil apresentava cerca de $16 \%$ de sua população jovem (entre 15 e 24 anos) sob a condição de analfabetismo. Ao compararmos com os outros países apresentados, podemos identificar que o Brasil, além de ser o país com a maior taxa de analfabetismo, em alguns casos, chega a ter mais de dez vezes de jovens analfabetos. 
campo de pesquisa sobre juventude no Brasil a partir da perspectiva de uma pluralidade cultural.

Novaes (2013) identifica na segunda metade da década de 1980 o período em que os “problemas da juventude” passaram a fazer parte da questão social e da agenda pública ${ }^{13}$. A autora avalia o contexto como uma das principais causas para que as questões referentes à juventude entrassem na agenda pública. Segundo a autora:

“(...) o aprofundamento dos processos de globalização dos mercados, a desterritorialização dos processos produtivos, a flexibilização das relações de trabalho atingiu, particularmente, a vida presente e as perspectivas de futuro dos jovens. A partir daí, a juventude começou a fazer parte das preocupações e entrou na agenda pública dos governos, da cooperação internacional e das agências bilaterais" (p.273)

Esse contexto de globalização dos mercados e propagação do sistema neoliberal descrito por Novaes tem como consequência um agravamento das condições de desigualdade e os jovens em situação econômica e social mais vulnerável acabam submergidos em condições de violência o que os enquadra na nomenclatura criada na época: "indivíduos em situação de risco ${ }^{14 \%}$.

Os jovens em situação de risco passam a ser alvo das ações, sobretudo de projetos sociais desenvolvidos por entidades governamentais e não governamentais (ONGs). Esses projetos sociais, em sua maioria, tinham dois objetivos principais: capacitação dos jovens para o mercado de trabalho e/ou contenção e prevenção da violência por meio de atividades culturais (música, grafite, teatro etc.). Sobre esse período, Novaes relembra a consigna “jovem não é problema, é solução”, a qual, segundo a autora foi disseminada como formar de evocar um "protagonismo juvenil” especificamente para os jovens de áreas pobres e violentas que serão apontados pela autora como "jovens de projeto" e que serão os responsáveis por desenvolver e divulgar uma cultura própria do local, a chamada "cultura de periferia”. (Novaes, 2013. P274). Apesar do alerta de Novaes para o fato de que o protagonismo desses jovens era apenas um "protagonismo pedagógico", ou seja, estimula a participação, mas não abre acesso para a construção de um espaço concreto na esfera pública.

O fluxo histórico das lutas pela participação na esfera pública, a conquista de um espaço na agenda pública, a valorização da cultura da periferia, isso tudo somado ao processo

\footnotetext{
13 A atenção dada às questões da juventude nesse período também tem relação com o fato de a ONU ter designado o ano de 1985 como o "ano internacional da juventude."

14 Cabe ressaltar que a "atenção" dada pelo Estado aos jovens e crianças em situação de risco até o final dos anos 1980, sobretudo a partir da Constituição e início dos anos 1990, sobretudo com o Estatuto da Criança e do Adolescente, era uma relação marcada pela violência. As normas jurídicas que existiam até esse período tinham como característica fundamental a ação punitiva. Para mais informações ver a tese de Rafaelle Monteiro de Castro: "Crianças e adolescentes enquanto sujeitos de direitos no Brasil pós- Eca: o Conselho Tutelar e a Rede de proteção" (2018). Disponível em: http://www.cis.pucrio.br/assets/pdf/PDF CIS 1540579608 Rafaelle_Monteiro de Castro_- 2018.pdf
} 
de redemocratização que confluiu na Constituição de 1988, marcam uma nova situação para os jovens que passam a ser tidos como "sujeitos de direitos" (Novaes, 2013).

No artigo 227 da Constituição de 88 Cidadã podemos observar a ênfase às garantias devidas aos jovens e crianças, por meio da expressão “absoluta prioridade”. De acordo com o artigo:

\begin{abstract}
“Art. 227 É dever da família, da sociedade e do Estado assegurar à criança, ao adolescente e ao jovem, com absoluta prioridade, o direito à vida, à saúde, à alimentação, à educação, ao lazer, à profissionalização, à cultura, à dignidade, ao respeito, à liberdade e à convivência familiar e comunitária, além de colocá-los a salvo de toda forma de negligência, discriminação, exploração, violência, crueldade e opressão".
\end{abstract}

A conquista dos direitos constitucionais foi o primeiro passo para o momento seguinte que foi a aprovação do Estatuto da Criança e do adolescente em 1990. Com efeito, podemos observar a partir desse momento a construção de uma série de medidas com foco na criança e no jovem, sobretudo medidas relacionadas à educação.

Após os marcos legais da Constituição de 1988 e do ECA, o direito à educação de qualidade passa a ser um direito fundamental ${ }^{15}$ dos jovens e crianças, além de uma obrigação coletiva que engloba o Estado, os responsáveis e a sociedade como um todo. Contudo, apesar do marco legal e da "universalização do acesso" à escola não correspondeu à universalização da escolarização. De acordo com Vanilda Paiva (2011) o projeto de democratização do acesso à educação, o qual ela denomina de "Revolução educacional ${ }^{16 "}$ acabou por incorrer na perda de qualidade, ou seja, a oferta de uma educação pública universal se concretizou, mas com séria perda da qualidade, não somente do ensino, mas do corpo de profissionais e até mesmo da estrutura física da escola.

Esse processo de "Revolução Educacional" teve grandes desafios por ampliar o acesso à educação a um número expressivo de alunos, por isso Paiva adverte que "Deve-se se ter claro que não se passa de 7\% a 30\% de escolarização, ou seja, de uma escola destinada a poucos a uma escola de massa, sem ter que enfrentar velhos e novos problemas de difícil equacionamento" (p.4).

\footnotetext{
15 É importante observar que a educação, vista como direito humano fundamental, já era observada no rol de Direitos Humanos desde a Declaração Universal dos Direitos Humanos de 1948, da qual o Brasil é signatário desde esse mesmo ano.

16 A autora refaz o processo do que ela chama de "Revolução Educacional", dividindo em três períodos. O primeiro que começa em meados dos anos 1940 e vai até o início dos anos 1960 é caracterizado pela expansão das escolas primárias nas cidades e da educação de jovens e adultos na zona rural. O segundo período começa na segunda metade dos anos 1960 passando pelos aos anos 1970 e chegando até meados dos anos 1980. Esse período é caracterizado pela grande difusão do ensino secundário no primeiro e segundo seguimento. Finalmente, o terceiro período diz respeito a grande Reforma Universitária, que ocorreu no início dos anos 1970.
} 
A autora chama atenção para a situação do Rio de Janeiro, o qual teria sido “especialmente atingido”. Em suas palavras: "Este estado é exemplar em sua radicalidade do que concerne a fenômenos que ocorram nacionalmente: elevado nível de privatização a todos os níveis e profunda segmentação social do sistema de ensino, mais visível na escola pública, mas também presente no sistema privado, com suas complexas causas e imensas, profundas e contraditórias consequências" (p.3). O Rio de Janeiro foi “exemplar”, devido à divisão profunda que ocorreu: De um lado, as escolas particulares que se multiplicaram com a promessa de um currículo de qualidade e uma infraestrutura completa, de outro os CIEPs (Centro Integrado de Educação Pública) que apesar do objetivo (absolutamente louvável) de oferecer uma educação "holística" com atenção ao esporte, assistência médica, alimentação saudável e acesso a diferentes atividades culturais, devido a uma série de ingerências negativas acabou por assumir o triste estereótipo de "escola de pobre". Paiva explica que

$$
\begin{aligned}
& \text { (...)palco de experimentos e intervenções "progressistas", os problemas do sistema } \\
& \text { público de ensino fundamental e médio complicaram-se a partir do Projeto dos } \\
& \text { CIEPS e sua administração fora da Secretaria da Educação, considerada um } \\
& \text { problema a ser evitado. No entanto, as belas escolas projetadas por Niemeyer para } \\
& \text { os pobres fracassaram, entre outros motivos, porque os pobres não queriam ser } \\
& \text { estigmatizados como alunos dos Brizolões"(...) Há uma escola pública na cidade } \\
& \text { mais visível, incluindo aí porções importantes da Zona Norte. E há uma escola } \\
& \text { pública que se modela para a "zona oeste" uma escola "para pobres".(p.6) }
\end{aligned}
$$

As consequências geradas por meio da precarização da escola pública, que culminam na construção do estereótipo "escola de pobre”, são analisadas por Monica Peregrino (2010) através do que ela chama de "dilema dos anos 90". Esse dilema consiste em identificar se a escola sofreu um processo de democratização "incorporando-se ao âmbito dos direitos sociais e civis (p.182)" no fluxo das conquistas dos anos 80 , ou se foi um processo de massificação que "fragilizou a estrutura e a legitimidade da escola" (p.183). Eis as hipóteses da pesquisadora: "a entrada dessa população (favelada e, portanto, representante da "pobreza" na escola) na instituição implicou a democratização da instituição? Ou implicou, ao contrário, sua massificação?” (p.118).

Para responder ao "dilema dos anos 90" 17 , a pesquisadora parte do que ela denomina de "mudança de rumo" na educação. Enquanto na década de 1980 a escola era entendida como a instituição responsável pela "distribuição menos desigual dos bens sociais" e havia uma preocupação com a democratização da escola, na década de 1990, o que "parece" ser uma continuidade do processo de democratização é, na verdade, uma "mudança do sentido da escolarização", visto que, para tentar reduzir os altos índices de reprovação e evasão da

\footnotetext{
17 É importante ressaltar que a pesquisadora realiza sua análise tendo como contexto a cidade do Rio de Janeiro.
} 
década anterior, os gestores desconstruíram os padrões de avaliação, gerando uma “degradação da estrutura institucional” (Peregrino, 2010, p.181).

Peregrino demonstra que o processo de democratização do acesso à escola na década de 1980 foi acompanhado pelas estratégias pedagógicas da "seletividade escolar", baseada em avaliações aplicadas aos alunos, e da "segregação positiva", baseada na divisão dos alunos em turmas e turnos de acordo com o desempenho. Essas situações produziam como "efeito colateral" índices muito altos de reprovação e evasão o que levou à mudança nos padrões de avaliação na década de 1990. Esse novo padrão de avaliação produziu "um cenário menos dramático" em termos de avaliação e repetência, contudo gerou "efeitos drásticos sobre os processos de escolarização" (2010, p.172).

\begin{abstract}
A década de 1990 marca a "transição" dos projetos de democratização da educação para a perspectiva (agora aparentemente dominante) da massificação da educação, esvaziada que está a escola, partir desse momento, de projetos coletivos que lhe deem sustentação. O que se vê são iniciativas de caráter pontual e compensatório cuja tônica se centra na "inclusão" dos pobres à escola. Portanto, mesmo que em todos os índices e características, a escola da década de 1990 se assemelhe à escola dos anos de 1980 (em alguns casos, houve até melhoria dos índices), houve uma mudança fundamental: o sentido da escolarização. (p.169)
\end{abstract}

Essa mudança no sentido da escolarização observada por Peregrino (2010) vai ao encontro das "intervenções progressistas" apontadas por Vanilda Paiva (2011), que teriam sido as responsáveis pela perda dos "níveis de qualidade aceitáveis" das escolas públicas, fazendo com que sobre elas caísse o estigma de "escola de pobre". Desta forma, "começa então a se anunciar uma proposta de "massificação" da escola que articula a ampliação do espectro de escolarização dos pobres ao custo da degradação da estrutura institucional (Peregrino, 2010, p. 181).

Um possível enfrentamento para essa mudança de sentido da escolarização é apresentado por Marcelo Burgos, ao propor que a escola deve se afirmar institucionalmente a partir de duas frentes de ação: uma diz respeito à questão da avaliação e, a outra, está relacionada à integração afetiva do aluno no universo escolar. Nas palavras do autor: “(...) para a escola se afirmar institucionalmente, ela precisa ser capaz de articular,
de um lado, medidas voltadas para a busca por resultados escolares mais
igualitários, e de outro, ações voltadas para fazer com que ela entre para valer no
jogo da disputa de identidades, criando um clima escolar capaz de produzir
sentimento de pertencimento e confiança no projeto escolar. Ou seja, fazendo com
que a escola passe de fato a fazer parte do mundo do sujeito que subsiste no aluno.
(p.13)

É interessante observar que esse possível enfrentamento para a questão da mudança do sentido da escolarização formulado por Burgos, também pode ser um caminho para equacionar o "dilema dos anos 90" apresentado por Peregrino, na medida em que as "medidas voltadas para a busca de resultados escolares mais igualitários" (Burgos, 2014) podem ser 
uma alternativa para a "seletividade escolar" (Peregrino, 2010) responsável pelos altos índices de reprovação. E as ações capazes de "produzir um sentimento de confiança e pertencimento" (Burgos, 2014) podem servir como uma forma de combater a "segregação positiva" (Peregrino, 2010) na medida em que, ao desenvolverem a noção de pertencimento, evitariam a evasão escolar.

Se, por um lado, a "massificação" é a responsável pela mudança de sentido da escola que somada à perda de investimentos faz com que a escola pública se torne a "escola de pobre", por outro, Marcelo Burgos (2014) aponta que também é efeito dela a redução dos índices de trabalho infantil.

\begin{abstract}
Agora, a escola se converte em via incontornável do processo de socialização das novas gerações, e o ingresso precoce no mundo do trabalho, caminho até então inevitável para boa parte dos filhos das famílias populares, passa a ser criminalizado: a massificação da escola avança ao mesmo tempo em que o trabalho infantil diminui. (Burgos, 2014 p. 12)
\end{abstract}

Aliás, o autor chama atenção para algo mais profundo e que está além da questão da "massificação" que é o entendimento da criança e do jovem como "sujeito de direitos". A nomenclatura "sujeito de direitos", que surge a partir da Carta de 88, é a expressão de um novo lugar do jovem diante da sociedade: eles passam pela configuração de "problema", "risco", e tornam-se indivíduos portadores de dignidade jurídica, ou melhor, podemos dizer que o paradigma da “doutrina da situação irregular do menor" foi substituído pelo paradigma da "doutrina da proteção integral da criança" (Burgos, 2014, p.11), ou ainda, que "saem da situação irregular que orientava o Código de Menores (de 1979)" e passam à "proteção integral $^{18}$ ", como aponta Fúlvia Rosemberg (2010, p.10).

As décadas de 1980 e 1990 foram palco de um debate acirrado sobre o lugar dos jovens na sociedade e esse movimento serviu de "porta de entrada" para a consolidação dos jovens em dois espaços: (i) na agenda pública e (ii) no campo das pesquisas sociais.

No campo das políticas públicas, em 2003, no primeiro ano de governo do presidente Luís Inácio Lula da Silva, o Programa Nacional do Livro didático (PNLD) que até esse momento tinha como foco a distribuição gratuita de livros didáticos para o ensino fundamental, foi ampliado por meio da resolução n³8 de 25 de Outubro de 2003, e passou a abranger todas as modalidades do ensino médio (técnico e EJA) em atendimento a LDB (Lei de Diretrizes e bases) n.9.394 de 1996 e a Constituição Federal de 1988 no que tange ao

\footnotetext{
18 Burgos (2014) acrescenta que a "doutrina da proteção integral da criança se dirige a todas as crianças e adolescentes, sem exceção, ao contrário da "doutrina da situação irregular do menor" que se dirigia a um determinado segmento da população infanto-juvenil. (p.11).
} 
fornecimento de materiais didáticos de forma gratuita nas escolas da rede pública. Em 2004 o FNDE (Fundo Nacional de Desenvolvimento Educacional) foi organizado pelo Ministério da Educação de modo a reservar recursos para o programa "Brasil escolarizado", o qual abarcava o PNLD, o PNLA (Programa Nacional do Livro Didático para alfabetização de Jovens e adultos), PNLD/ EJA (Programa Nacional de Livros Didáticos para Educação de Jovens e Adultos), bem como o PNAE (Programa Nacional de Alimentação Escolar), PDDE (Programa Dinheiro Direto na Escola) e PNATE (Programa Nacional de Apoio ao Transporte Escolar) ${ }^{19}$. Ainda no ano de 2003 outra medida interessante que nos ajuda a compor esse contexto de protagonismo do Governo Federal com foco em políticas públicas voltadas para a educação, foi o estabelecimento da Lei 10.639/03 que tornou obrigatório o ensino da história e cultura afro-brasileira e africana para as escolas das redes públicas e particulares, do ensino fundamental até o ensino médio. A partir da metade do primeiro mandato do presidente Luiz Inácio Lula da Silva, mais precisamente em 2005, a criação de espaços institucionais/governamentais de juventude, responsáveis, tanto por organizar um orçamento específico para ações voltadas para a juventude, quanto por articular canais de participação começam a ser colocadas em prática.

Novaes (2013) nos ajuda a organizar uma, digamos, linha do tempo, com os espaços criados para a juventude na agenda pública, da seguinte forma:

\begin{tabular}{|l|}
\hline 2005 \\
\hline Secretaria Nacional de Juventude (SNI) \\
\hline Conselho Nacional da Iuventude (CONIUVE) \\
\hline Programa Nacional de Inclusão de Jovens (PROJOVEM) \\
\hline 2010 \\
\hline PEC da juventude (Emenda Constitucional 65) \\
\hline 2013 \\
\hline Estatuto da Juventude \\
\hline
\end{tabular}

A lei 11.129 , de 30/06/2005 ${ }^{20}$ representou um marco na relação do Estado com as juventudes. A partir desse marco legal foi criada a Secretaria Nacional de Juventude (SNJ)

\footnotetext{
19 Esses podem ser consultados no endereço eletrônico: http://www.fnde.gov.br/

20 Outra lei extremamente importante (também) para a juventude, visto que trata de recursos a serem destinados à educação, foi a Lei n. 11.494, de 20/06/2007. Essa lei nasce como Emenda Constitucional (n. 53, de 19/12/2006), atribuindo nova redação ao parágrafo $5^{\circ}$ do art. 212 da Constituição Federal e ao art. 60 do Ato das Disposições
} 
que surge com orçamento específico e com a proposta de mobilizar uma série de GTIs (Grupos de trabalho interministeriais). Nesse mesmo bojo é criado o CONJUVE (Conselho Nacional de Juventude) para discutir, fomentar e avaliar políticas públicas para a juventude, além do PROJOVEM (Programa Nacional de Inclusão de Jovens) que tinha como objetivo fornecer orientação profissional e auxílio de cem reais aos jovens com idade entre 18 e 24 anos que desejassem concluir o ensino fundamental ${ }^{21}$. Em 2006 foi regulamentada pela Medida Provisória n. 339 de 28/12/2006 que foi convertida na Lei n.11.494 de 20/06/2007 a criação de um fundo que unificou um conjunto de 27 fundos (26 estaduais e 1 do Distrito Federal) com objetivo de otimizar um orçamento específico e exclusivo para a valorização dos professores e desenvolvimento de ações para a manutenção de todas as etapas da educação (exceto do ensino superior). O Fundeb (Fundo de Manutenção e Desenvolvimento da Educação Básica e de Valorização dos Profissionais da Educação) ajudou a diminuir as diferenças regionais no setor da educação e estabeleceu prioridades a partir da ampla discussão com setores significativos da sociedade. No ano de 2007 foi criado, com base no PDE (Plano de Desenvolvimento da Educação), o IDEB (Índice de Desenvolvimento da Educação Básica). O objetivo desse indicador que foi desenvolvido pelo INEP era medir a qualidade da educação básica no Brasil, por meio de dois dados referenciais: a) o desempenho dos estudantes em exames nacionais padronizados (prova Brasil ou SAEB) e b) o rendimento escolar (tempo médio de conclusão de uma série).

É interessante apontar aqui a importância dessas medidas do Governo Federal para promover uma maior ampliação dos direitos como medida essencial para ampliar o reconhecimento da diversidade e atacar as desigualdades persistentes. Em $2010^{22}$ por meio da PEC da Juventude foi possível incluir na Constituição Federal o reconhecimento e a priorização da juventude no Capítulo de Direitos e garantias Fundamentais. O Estatuto da Juventude é aprovado em 2013 e de acordo com o próprio documento “determina quais são os direitos dos jovens que devem ser garantidos e promovidos pelo Estado brasileiro, detalhando garantias já previstas pela Constituição Federal de 1988 com maiores especificidades ao público jovem”. O Estatuto é um marco fundamental que consolida uma relação promissora entre Estado e as juventudes. Sancionado pela Presidenta Dilma Rousseff

\footnotetext{
Constitucionais Transitórias. A partir dela o governo criou o Fundo de Manutenção e Desenvolvimento da Educação Básica e de Valorização dos Profissionais da Educação (FUNDEB). Deste modo, o Fundo foi regulamentado pela Medida Provisória n. 339, de 28/12/2006.

21 Todos esses programas podem ser analisados com mais detalhes por meio do artigo "Movimentos, redes e novos coletivos juvenis: um estudo sobre pertencimentos, demandas e políticas públicas de juventude" de Regina Novaes.

22 Nesse mesmo ano, o Artigo 227 da Constituição Federal recebe a Emenda constitucional n. 65 de 13 de julho de 2010 a qual "altera a denominação do Capítulo VII do Título VIII para "cuidar dos interesses da juventude".
} 
após as "Jornadas de $2013^{23}$ ", representa uma vitória e ao mesmo tempo um desafio para os gestores de políticas públicas voltadas para a juventude. Esse desafio consiste no fato de ter que abranger a diversidade e o direito a igualdade. Podemos afirmar que o Estatuto é a expressão de uma correlação de forças que procura resolver a ideia (ultrapassada) de que a juventude, por ser uma "incompletude" ou uma "transição" não mereceria atenção específica por meio de recursos públicos e até mesmo de direitos. Embora o ECA já tivesse marcado uma conquista de direitos voltados (também) para os jovens seu foco é na proteção, a diferença com relação ao Estatuto é que o foco desse está na participação, ou seja, na garantia de espaços democráticos para que o jovem experimente aquilo que Hannah Arendt (2014) chamou de "segundo nascimento" que é a participação na esfera pública.

No campo das pesquisas sociais, Novaes (2007) expõe que os estudos financiados pela Unesco contribuíram para a elaboração de programas e parcerias com Estados e com o Governo Federal promovendo financiamentos para estudos voltados para a promoção de políticas públicas para a juventude.

Os estudos financiados pela Unesco, a partir dos anos 2000, foram fundamentais devido a sua característica de abarcar as diversas dimensões da juventude no Brasil. Novas perspectivas teórico-metodológicas também passaram a ser desenvolvidas revisando as diversas abordagens sobre a juventude brasileira a partir dos diferentes contextos sociais nos quais esses jovens estão inseridos. Deste modo, surgem novos repertórios de análise, tais como a violência, o protagonismo juvenil e as formas de sociabilidade. Nesse contexto, a coletânea "Retratos da juventude brasileira: análise de uma pesquisa nacional (Abramo \& Branco) merece ser destacada como um dos primeiros esforços na direção de uma pesquisa sobre juventude no âmbito nacional. Outras pesquisas também foram financiadas pela $\mathrm{UNESCO}^{24}$ e foram de grande importância para construir um repertório qualificado de dados sobre os jovens e para consolidar esse campo de estudos.

O processo de construção dos jovens enquanto sujeito de direitos foi feito por meio da ampliação dos canais de diálogo, do incentivo às pesquisas sobre os temas que envolvem a juventude e de políticas públicas. Além disso, buscou-se aprofundar essa dimensão dos direitos levando as políticas públicas para campo da ação ao entender os jovens como protagonistas de novos direitos e realidades.

\footnotetext{
23 Jornadas de 2013 é a designação para uma confluência de manifestações que ocorreram nos meses de junho e julho de 2013 em diversas cidades brasileiras e que tiveram como estopim o aumento das passagens de ônibus, mas que, com o decorrer de seu desenvolvimento apresentaram uma série de outras reivindicações, sobretudo com relação a direitos sociais.

24 Podemos citar alguns exemplos, tais como: Mapa da violência (1998), Jovens acontecendo na trilha das políticas públicas (2005), Juventude, violência e cidadania (2005).
} 
Contudo, as desigualdades estruturais presentes na sociedade brasileira ainda produzem constrangimentos que não foram eliminados.

A pesquisa Juventude, cultura cívica e cidadania apresentará duas realidades que, conforme a expressão por um dos jovens da rede privada, entrevistado nos grupos focais, "se encontram na mesma calçada”, mas vivem realidades completamente diferentes".

Os jovens da nossa pesquisa são estudantes do ensino médio, da rede pública e particular, com idade média de 16 anos e que moram na cidade do Rio de Janeiro. A escolha por esse "perfil" de jovens consistiu em buscar as percepções sobre cidadania e cultura cívica, de um grupo que possui o que Angela Paiva (2011) chamou de "cognoscibilidade", ou seja, que possuam reflexividade para responder sobre os temas centrais da pesquisa. Além disso, a escolha por jovens matriculados nas duas redes de ensino (particular e privada) também buscou observar até que ponto as desigualdades em que estão inseridos, interfere em suas percepções.

Os jovens da rede pública que conseguem chegar ao ensino médio, representam o que Peregrino chama de uma "minoria sobrevivente" (2010, p.18) e que Paiva Corrobora ao dizer que: "a maioria deles sobreviveu a um sistema escolar injusto, que expulsa a metade de seus alunos quando estes iniciam o ensino médio, e vivenciam realidades escolares muito distintas, dependendo da rede e da escola que têm condições de frequentar" (Paiva,2011.p. 8)

Alguns números podem também nos ajudar a ilustrar o contexto e que são os jovens que nossa pesquisa buscou auscultar as percepções.

No ano de $2018^{25}$, de acordo com dados do PNAD/CENSO, cerca de $20 \%$ dos alunos de ensino médio da Rede Estadual do Rio de Janeiro ficaram reprovados ou evadiram. Os altos índices de reprovação apresentados no fundamental II e no ensino médio quando somados ajudam a construir a realidade da "distorção idade/série" apresentada na tabela a seguir:

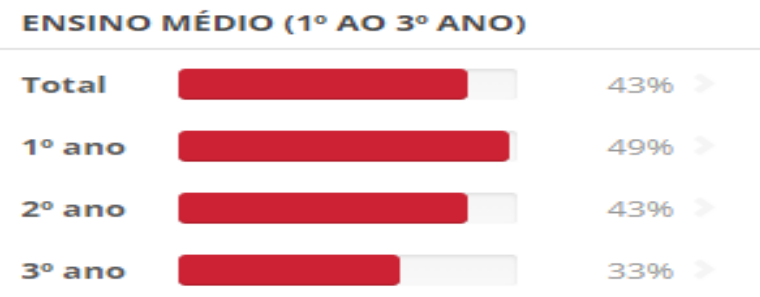

Fonte: qedu.org.br

25 Dados obtidos em: https://www.qedu.org.br/estado/119-rio-de-janeiro/taxas-rendimento/redeestadual/urbana?year $=2018$ 
Podemos observar que quase $50 \%$ dos alunos que chegam ao primeiro ano do ensino médio não estão na idade ideal para a série. Esses são apenas alguns dos dados que nos ajudam a mostrar essa situação de "sobrevivência" na qual estão inseridos os jovens alunos do ensino médio.

De acordo com dados PNAD/CENSO a educação pública estadual é responsável por cerca de $70 \%$ dos jovens matriculados no ensino médio e a rede privada por cerca de $30 \%$.

\section{Estudantes de Ensino Médio - Rio de Janeiro}

(RJ)

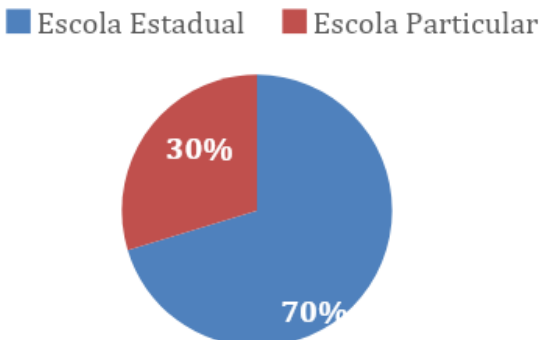

Apesar de ser o responsável pela maioria dos jovens a rede pública estadual é a que apresenta as piores condições de infraestrutura e é a que possui o maior número de docentes "não habilitados" ou sem licenciatura para a área em que atuam.

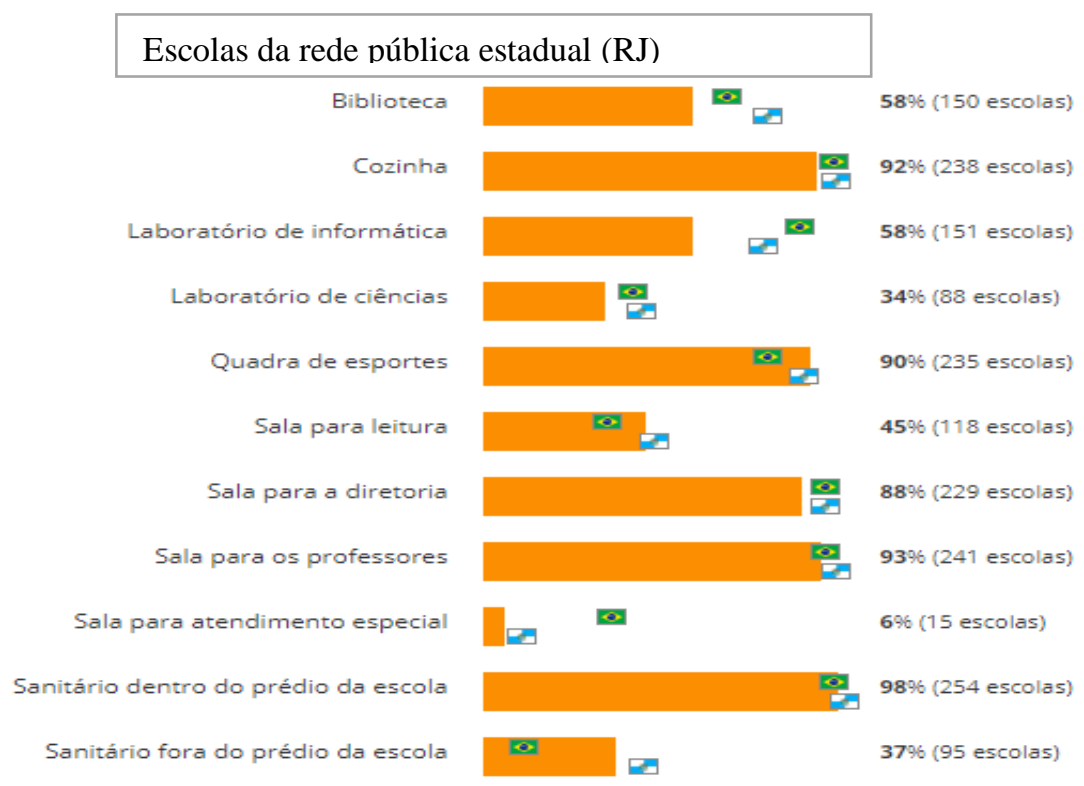

la de leitura,

a presença da biblioteca está em um pouco ma1s da metade dessas escolas, $58 \%$, mesma porcentagem da quantidade de escolas que dispõem de laboratórios de informática. Com relação ao número de escolas com laboratório de ciências o número é ainda menor, apenas $34 \%$ dispõe desse equipamento. 
A realidade da infraestrutura das escolas particulares é bem diferente da pública. Quase $80 \%$ dessas escolas possuem bibliotecas, a presença da sala de leitura é observada em $56 \%$, a metade delas possuem laboratórios de ciências e $70 \%$ possuem laboratórios de informática.

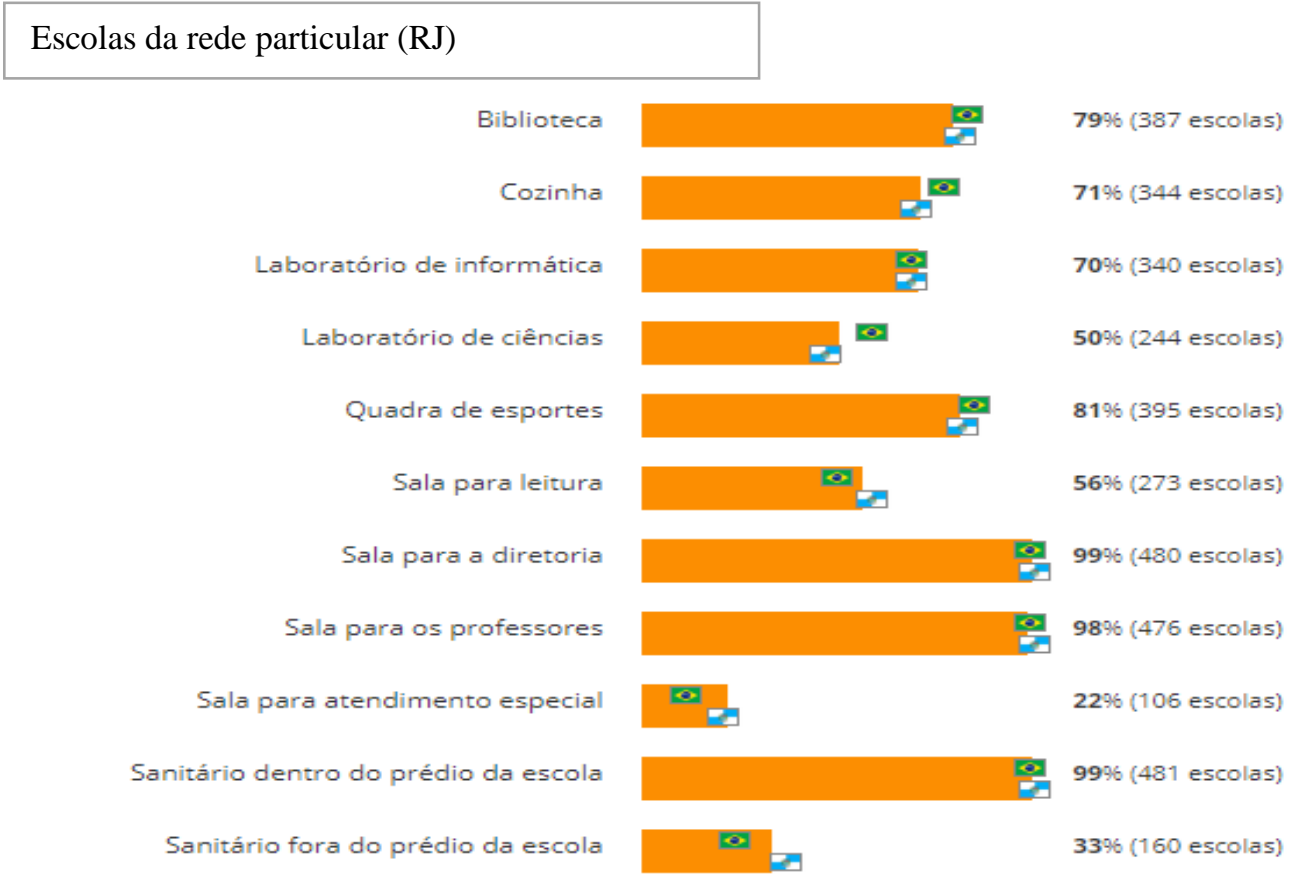

Fonte Censo Escolar/INEP 2018 | Total de Escolas de Educação Básica: 487 | QEdu.org.br

Além dos aspectos relacionados à infraestrutura outro indicador da desigualdade existente entre escolas da rede pública e particular do Rio de Janeiro está na qualificação, ou na falta dela, com relação ao corpo docente. Os dados apresentados abaixo são do Inep/Censo $2019^{26}$ demonstram que cerca de $30 \%$ dos professores da rede estadual da região sudeste não possuem formação na área de atuação.

Uma parte das consequências dos dados demonstrados anteriormente está nos diferentes índices de aproveitamento entre alunos da rede pública. De acordo com o resultado do $\operatorname{Ideb}^{27} 2019$, as escolas da rede estadual do Rio de Janeiro não atingiram a meta projetada ficando com a nota 3,5 .

Dados da PNAD 2019 recentemente publicados mostram que o maior gargalo da educação está na passagem dos alunos do Ensino Fundamental II para o Ensino Médio. Os indivíduos com idade entre 6 e 14 apresentam um percentual de escolarização de 89,2\%, mas

\footnotetext{
26 Dados obtidos em: jornal “O Globo" (09/02/2020): https://g1.globo.com/educacao/noticia/2020/02/09/40percent-dos-professores-de-ensinomedio-nao-sao-formados-na-disciplina-que-ensinam-aos-alunos.ghtml

27 A nota do Ideb é calculada a partir dos dados obtidos no Censo Escolar e dos resultados dos estudantes nas avaliações oficiais do Inep do Sistema de Avaliação da Educação Básica (Saeb). O Saeb compreende três avaliações: a ANA (Avaliação Nacional da Alfabetização), a Aneb (Avaliação Nacional da Educação Básica) e a Anresc (Avaliação Nacional do Rendimento Escolar), mais conhecida como Prova Brasil.
} 
essa taxa cai vertiginosamente para o seguimento seguinte composto por jovens com idade entre 15 e 17 anos. Nessa faixa etária o percentual de escolarização representa apenas 32,4\%. Dentre os principais motivos para a evasão escolar estão: necessidade de trabalhar $(39,1 \%)$, falta de interesse $(29,2 \%)$ e gravidez $(23,8 \%)$. Além desses dados sobre evasão, a PNAD também apresentou dados sobre "distorção idade/série". Mais de 70\% dos jovens com idade entre 15 e 17 anos não estão na etapa escolar adequada. A desigualdade racial também se faz presente com mais força entre os jovens. Em 2019 a taxa de analfabetismo na população com 15 anos ou mais foi de $12,5 \%$, sendo que a população branca representa 3,6\% desse percentual, enquanto pretos e pardos 8,9\% (quase o triplo). Embora, nos últimos anos, tenha sido observado um aumento da taxa líquida de alunos na rede pública estadual. Podemos identificar que esse aumento da taxa líquida de alunos na rede estadual do Rio de Janeiro está relacionado a ação denominada de "aprovação automática" da rede municipal. Contudo, esses dados não refletem uma alteração significativa na dinâmica das reprovações e de evasão que continuam alta ao longo do ensino médio.

Com relação aos aspectos macros que nos ajudam a construir um quadro sobre o contexto no qual estão inseridos os jovens alunos da rede particular, infelizmente não podemos contar com dados oficiais do $\mathrm{Ideb}^{28}$, mas uma busca pelas notas do Enem pode contribuir com nosso propósito aqui. Desde 1999, quando esse exame passou a servir como meio de ingresso nas universidades, as melhores notas apresentadas são de escolas particulares. O resultado do ranking Enem $2019^{29}$ com escolas da cidade do Rio de Janeiro apresenta até a $32^{\circ}$ posição apenas escolas particulares, sendo que a $33^{\circ}$ posição é de uma escola pública federal. A primeira escola estadual que aparece na lista encontra-se na $201^{\circ}$ posição.

Os dados apresentados anteriormente ganham dimensão ainda mais dramática quando se verifica que os estudantes da rede pública estadual representam cerca de $70 \%{ }^{30}$ do total de jovens matriculados no ensino médio. Conforme apresentado nas tabelas a seguir.

\footnotetext{
28 O Ideb começou a ser realizada nas escolas particulares em 2017, mas com caráter voluntário. Destas, forma não conseguimos dados suficientes para fazermos a comparação aqui.

29 Esses dados foram divulgados pelo Governo Federal até 2016. O motivo para o fim da divulgação desses dados, consiste no fato das escolas particulares estarem usando essas informações para fazer propaganda. Atualmente quem consolida e divulga essas informações é a imprensa. Os dados apresentados aqui foram obtidos por meio de um levantamento realizado pela Folha de São Paulo e divulgado em 2/07/2020 no seguinte endereço eletrônico: https://www1.folha.uol.com.br/cotidiano/2020/07/veja-o-desempenho-da-sua-escola-no-enem-2019.shtml

30 Dados obtidos em: https://qedu.org.br/cidade/2801-rio-de-janeiro/censoescolar?year $=2018 \&$ dependence $=0 \&$ localization $=0 \&$ education stage $=0 \&$ item $=$
} 
Números das escolas particulares: escolas e matrículas

\begin{tabular}{|l|r|}
\hline Total de Escolas Particulares de Educação Básica & \\
\hline Brasil & 8.129 \\
\hline Rio de Janeiro - Estado & 1.093 \\
\hline Rio de Janeiro - Capital & 487 \\
\hline
\end{tabular}

\begin{tabular}{|l|r|}
\hline $\begin{array}{l}\text { Total de Matrículas Escolas Particulares de Educação } \\
\text { Básica }\end{array}$ & \\
\hline Brasil & 898.779 \\
\hline Rio de Janeiro - Estado & 113.539 \\
\hline Rio de Janeiro - Capital & 59.154 \\
\hline
\end{tabular}

Números das escolas públicas estaduais: escolas e matrículas

\begin{tabular}{|l|r|}
\hline $\begin{array}{l}\text { Total de Escolas Públicas Estaduais de Educação } \\
\text { Básica (Urbanas) }\end{array}$ & \\
\hline Brasil & 16.938 \\
\hline Rio de Janeiro - Estado & 1.027 \\
\hline Rio de Janeiro - Capital & 260 \\
\hline
\end{tabular}

\begin{tabular}{|l|r|}
\hline $\begin{array}{l}\text { Total de Matrículas Escolas Públicas Estaduais de } \\
\text { Educação Básica (Urbanas) }\end{array}$ & \\
\hline Brasil & 5.852 .533 \\
\hline Rio de Janeiro - Estado & 384.706 \\
\hline Rio de Janeiro - Capital & 139.994 \\
\hline
\end{tabular}

Deste modo, temos que a cada 10 jovens estudantes do ensino médio na cidade do Rio de Janeiro, 7 estão matriculados em escolas públicas e sujeitos a um ensino de qualidade precária e com condições de infraestrutura medíocres que produzem uma situação que Angela Paiva (2013) chamou de "apatheid educacional" e que Vera da Silva Telles (data) identifica como a expressão de um acordo societário incompleto. Esse é o quadro com que trabalhamos na pesquisa junto aos jovens das redes pública e particular de ensino médio de três áreas da Cidade do Rio de Janeiro.

\section{2}

\section{Desigualdades e simetrias: uma comparação dos primeiros resultados}

Depois de construirmos esse quadro "macro" que expõe o contexto no qual os jovens da pesquisa estão inseridos, vamos aproximar nossa análise das questões mais específicas, das percepções desses jovens, e começaremos pelas respostas deles sobre "o que é ser jovem no Brasil?" 
Tabela 1.0

\begin{tabular}{|c|c|c|c|c|c|c|c|}
\hline \multirow{2}{*}{\multicolumn{2}{|c|}{ Pesquisa atual }} & \multicolumn{6}{|c|}{ Ser jovem no Brasil é } \\
\hline & & $\begin{array}{l}\text { Não se } \\
\text { aplica }\end{array}$ & $\begin{array}{l}\text { Mais difícil } \\
\text { que num } \\
\text { país } \\
\text { desenvolvi } \\
\text { do }\end{array}$ & $\begin{array}{c}\text { Apesar } \\
\text { de tudo } \\
\text { é bom } \\
\text { porque } \\
\text { as } \\
\text { coisas } \\
\text { ainda } \\
\text { estão } \\
\text { por ser } \\
\text { feitas }\end{array}$ & $\begin{array}{l}\text { Igual a } \\
\text { ser } \\
\text { jovem } \\
\text { em } \\
\text { qualquer } \\
\text { lugar }\end{array}$ & $\begin{array}{c}\text { Dá muita } \\
\text { insegurança }\end{array}$ & outro \\
\hline \multirow{2}{*}{ Escola } & Pública & $0,00 \%$ & $32,60 \%$ & $10,10 \%$ & $4,50 \%$ & $52,80 \%$ & $0,00 \%$ \\
\hline & $\begin{array}{l}\text { Particula } \\
\text { r }\end{array}$ & $1,30 \%$ & $25,00 \%$ & $10,60 \%$ & $10,60 \%$ & $40,00 \%$ & $12,50 \%$ \\
\hline
\end{tabular}

As respostas dos jovens de escola pública e particular se aproximam em duas opções: em primeiro lugar com "dá muita insegurança", e em seguida, "mais difícil que num país desenvolvido". É interessante observar como apesar das condições de desigualdade que marcam profundamente a situação desses jovens, eles se apresentam uma percepção muito próxima sobre a condição de "ser jovem".

Na primeira pesquisa realizada, Angela Paiva identificou essa situação relacionada aos aspectos que aproximam e que distanciam as percepções desses jovens como "desigualdades e simetrias". Naquela época, a percepção dos jovens sobre a condição de juventude também mostrava "simetrias". Conforme pode ser visto na tabela a seguir, cerca de $30 \%$ dos jovens da rede pública e particular, acreditavam que ser jovem gerava sentimento de insegurança (“dá muita insegurança"). Ao compararmos esses dados, observamos um salto de cerca de $20 \%$ para essa opção.

Esse aumento pode ser entendido por meio do conceito de "marcos geracionais" formulado por Regina Novaes (2001). Para a autora, apesar da desigualdade e da diversidade que são as marcas inerentes da juventude, existem três "marcos geracionais ${ }^{31}$ " que são "experiências geracionais comuns", ou seja, condicionantes sociais que se mantém de uma geração para a outra. Aqui, observamos claramente a manifestação do marco geracional da "insegurança" com o aumento na porcentagem de jovens que afirmam definir sua condição de juventude a partir desse sentimento.

\footnotetext{
31 Os outros marcos geracionais apresentados por Novaes (2006) dizem respeito a linguagem da comunicação visual (Internet) e o medo da violência urbana. Ambos serão explorados neste trabalho nos tópicos a seguir.
} 
Tabela 2.0

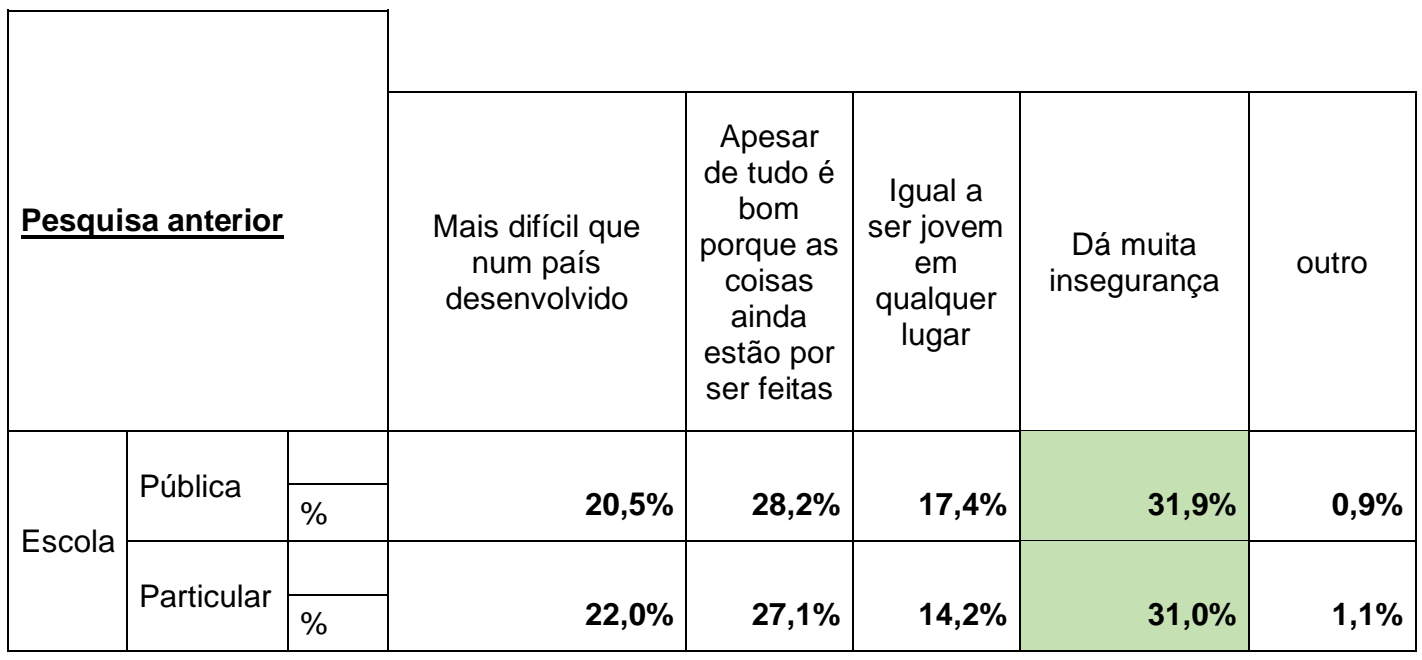

A queda da porcentagem de jovens que escolheram a opção "Apesar de tudo é bom porque as coisas ainda estão por ser feitas" pode nos dar pistas para algumas mudanças na percepção que esses jovens têm sobre a sua própria condição. Enquanto na primeira pesquisa essa opção figurava como a segunda mais escolhida, na atual aparece como terceira opção, ficando a opção "mais difícil que num país desenvolvido" em segundo lugar.

A queda da porcentagem relativa à opção "Apesar de tudo é bom porque as coisas ainda estão por ser feitas" e o aumento na porcentagem da opção "Mais difícil que num país desenvolvido" pode apresentar uma relação direta com o contexto atual explicitado na fala de um jovem de escola particular da Zona Sul.

\footnotetext{
"A tendência é só piorar. Eu não vejo nossa democracia como muito estável e não vejo o futuro com algo bom"(...) historicamente o Brasil foi muito abandonado pelo poder público e é difícil reverter isso politicamente porque as pessoas já estão meio que acostumadas a viver sem a ajuda de qualquer tipo de instituições (...) pode acontecer, mas a gente tem que fazer todo um trabalho até chegar nesse ponto" (Rede privada. Zona Sul. 2019).
}

Nesse momento, é importante que façamos uma pequena contextualização com relação às duas pesquisas. Enquanto a primeira (realizada entre 2004 e 2005) tinha como contexto uma sociedade que, embora não tivesse resolvido seus constrangimentos referentes à desigualdade, já experimentava quase vinte de consolidação da democracia, a segunda pesquisa, realizada a partir de 2018 , teve como contexto um período de eleições fortemente marcado pelo crescimento da extrema direita. 
Nos dois grupos focais realizados em escolas particulares existem falas de jovens indicando diálogos e discussões que aconteceram no ambiente familiar e escolar com relação a disputa eleitoral ocorrida. A percepção sobre a vitória de um presidente que possui orientação dos ideais da extrema direita aparece em diversas falas com tom de descrédito e desalento dos jovens com relação à expectativa do próprio futuro e o do país. Não podemos afirmar de modo objetivo, mas, é provável que a chegada ao poder de um presidente que ameaça a conquista de direitos que vinha acontecendo de modo contínuo seja uma das explicações para esse possível pessimismo dos jovens com relação a sua condição de juventude.

Mas voltando à proposta de mostrar as desigualdades educacionais das duas redes de ensino e de mostrar as "desigualdades e simetrias" tal como foi feito por Paiva (2013) na pesquisa anterior, vamos observar os dados sobre a escolaridade dos pais desses jovens a seguir.

Tabela 3.0

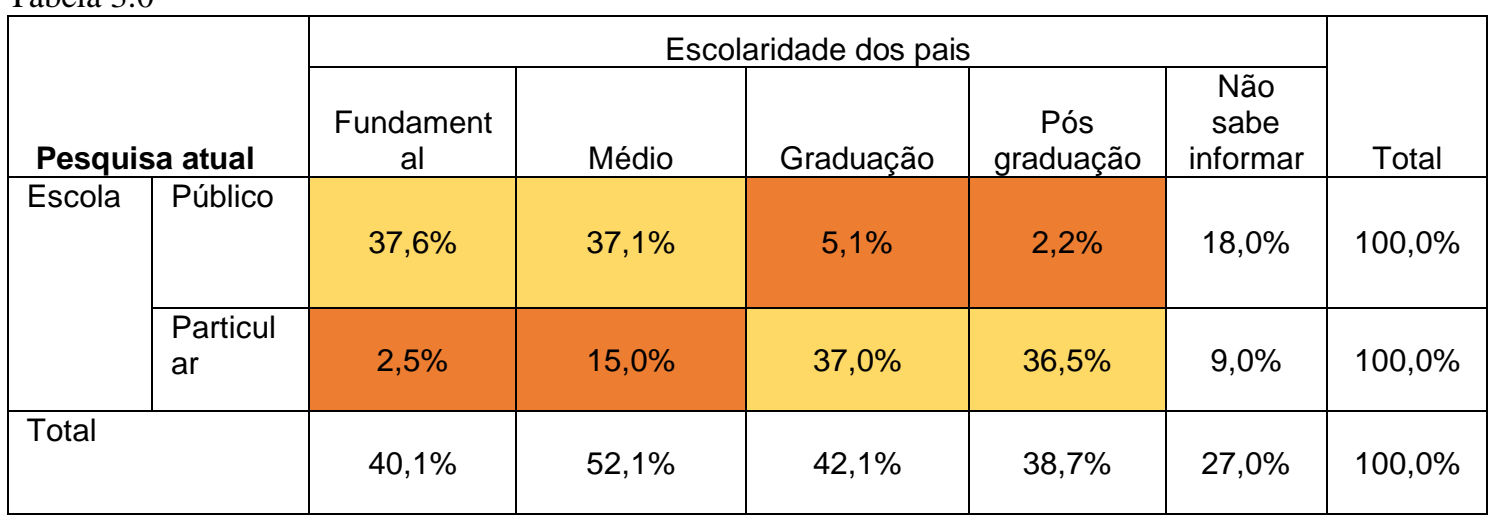

Os dados que apresentam a escolaridade dos pais demonstram desigualdades que persistem desde a primeira pesquisa. Naquela época, os dados apresentados eram os seguintes: os pais dos jovens de escolas públicas tinham, em sua maioria, (cerca de 40\%) ensino fundamental ou ensino médio, já os pais dos jovens da rede privada estavam concentrados (cerca de 50\%) no grupo daqueles que tinham ensino superior e pós-graduação. Ao observarmos a tabela 3.0, observamos que as diferenças educacionais entre os pais de jovens de escola pública e os de escola particular persistem. 
Gráfico 1.0

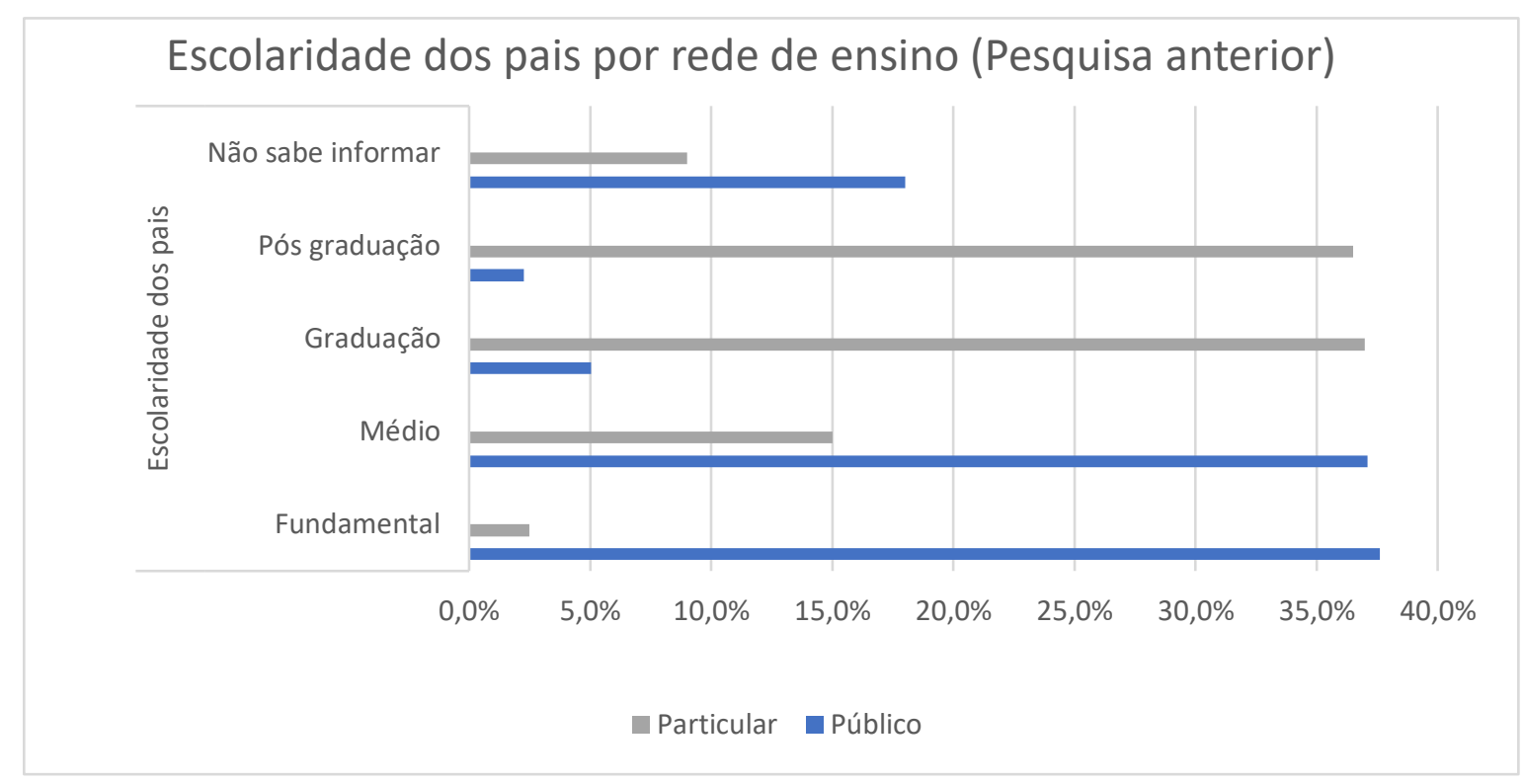

O conceito de "capital cultural" de Bourdieu nos ajuda a elaborar a interpretação de causas e consequências para essa desigualdade persistente. De acordo com Bourdieu existe uma espécie de "moeda" que as classes dominantes utilizam para acentuar as diferenças e que é transmitida como "herança" para seus filhos. Essa "moeda" que não possui valor monetário, mas um valor simbólico pois trata-se de um repertório cultural, é acumulado pelos indivíduos ao longo de suas vidas. Esse acúmulo de repertório cultural é denominado por Bourdieu como "capital cultural".

Os indivíduos das classes dominantes estabelecem quais são os elementos que compõem esse capital cultural e desenvolvem sua estrutura valorativa, além disso, o repertório desenvolvido e aplicado pelo sistema de educacional reforça e mantém o valor desse "capital cultural". Desta forma, quem tem acesso à educação de qualidade, também tem acesso à "moeda" de alto valor simbólico que ajuda a construir o "capital cultural".

Observando os dados da tabela 2.0, podemos concluir que a presença do "capital cultural" apresenta um traço forte de manutenção da desigualdade, visto que, mesmo tendo passado quinze anos (tempo de uma pesquisa para a outra) a diferença do nível educacional entre os pais dos jovens de escola pública e particulares, se mantém praticamente inalterada.

Existe uma situação perversa nesse dado que é uma espécie de ciclo vicioso de desigualdades. Quando um indivíduo, detentor de capital cultural tem um filho, ele automaticamente transmite, por meio do habitus primário, essa "herança cultural" para seu "herdeiro" (Bourdieu, Passeron, 1973), esse "herdeiro" transmitirá essa herança a seus descendentes e esse ciclo, que dificilmente será quebrado, é mantido. Temos assim, a 
reprodução de gerações e mais gerações de "herdeiros". Por outro lado, os não herdeiros também são colocados em ciclo próprio quando as situações de déficit de capital cultural se reproduzem de geração para geração, fazendo com que estejam sempre distantes de alcançar o valor do capital cultural estabelecido pelas sequências de gerações de herdeiros. A escola pode ser o momento em que esse capital cultural herdado pode ser alterado. Daí sua importância nas trajetórias de vida dos jovens que não dispõem dos mesmos recursos culturais e sociais na sua trajetória inicial.

Diante dessa situação que sugere uma "reprodução" das desigualdades, cabe uma pergunta: Qual a percepção desses jovens sobre a escola? Será que percebem a escola como o lugar próprio para um sistema de "reprodução" ou será que entendem a escola como uma instituição que detém as ferramentas adequadas para habilitá-los para o mundo dos adultos? Sobre a confiança desses jovens com relação à escola temos os seguintes dados:

Gráfico 2.0

Confiança na escola - Atual

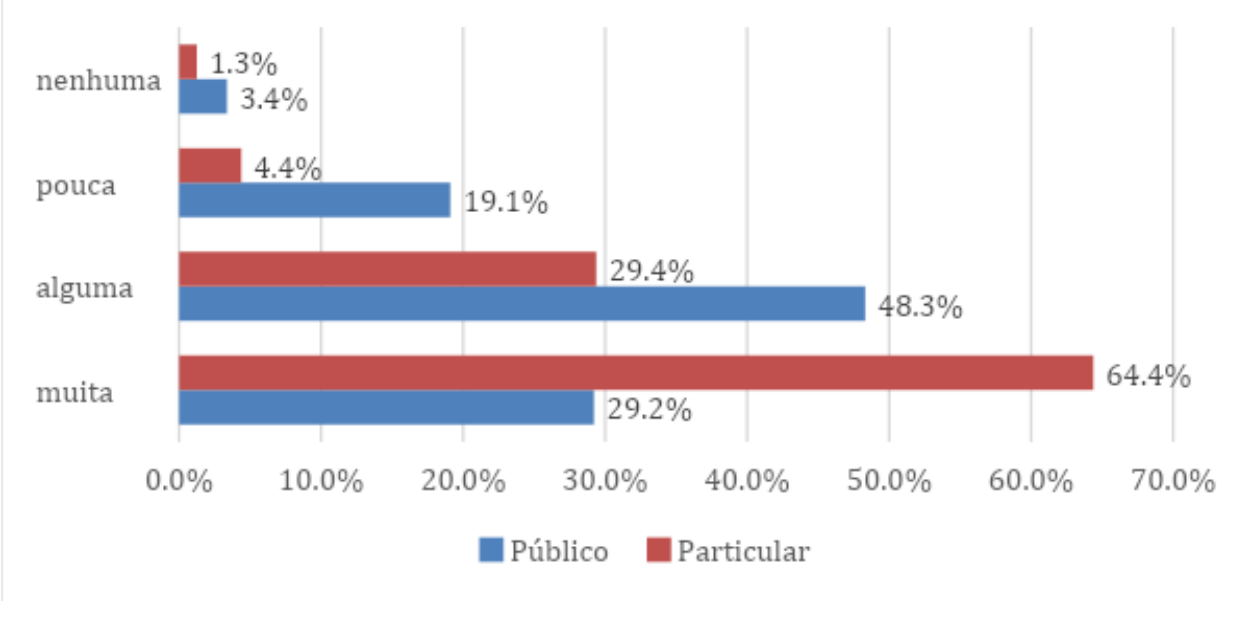

A confiança dos estudantes da rede pública se concentra mais nas opções "pouca" ou "alguma" confiança, enquanto os da rede particular concentram suas respostas em "alguma" e "muita".

Para analisar melhor esses dados, agrupamos as variáveis em dois rótulos ${ }^{32}$ : visão pessimista e visão otimista da escola. De posse desses dados, elaboramos o gráfico abaixo.

\footnotetext{
32 Esse rótulo foi construído da seguinte maneira: somamos as porcentagens de "nenhuma" e "pouca" confiança e atribuímos o rótulo de "visão pessimista da escola". A soma dos rótulos "alguma" e "muita" deu origem ao rótulo "visão otimista da escola".
} 
Gráfico 2.1

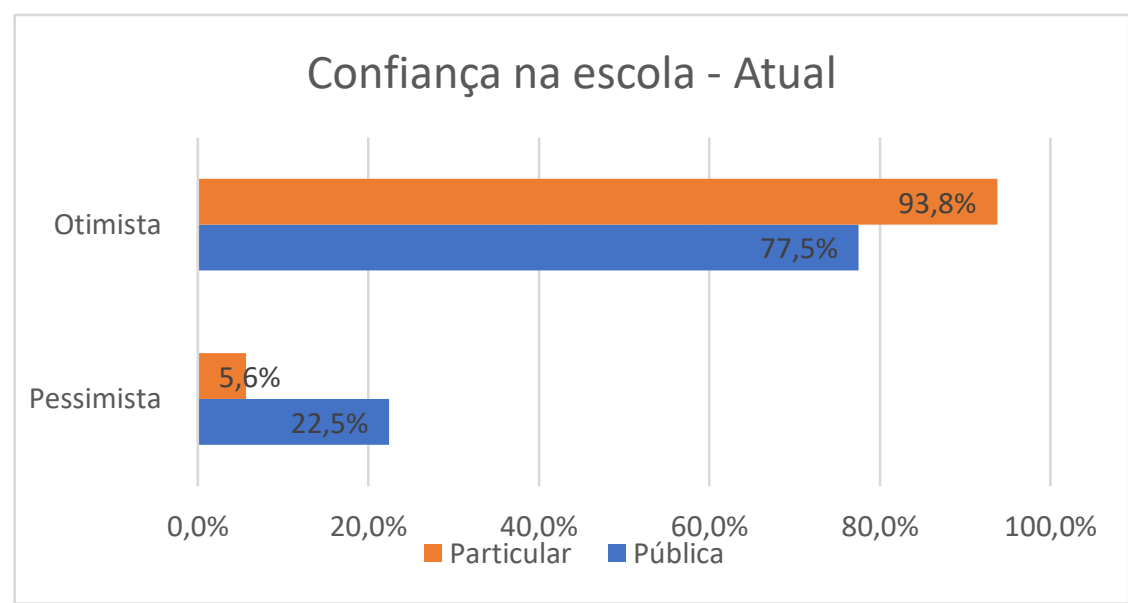

Por meio desse gráfico, podemos perceber que tanto os jovens de escola particular, quanto os jovens de escola pública, apresentam uma visão otimista da escola. Embora essa visão tenha uma porcentagem maior entre os alunos da escola particular, ela é de apenas 30\%, ficando a visão otimista da escola com $70 \%$ do total.

A visão otimista que os jovens da rede pública possuem da escola, talvez tenha relação com o que Maria Lígia Barbosa e Maria Josefina Sant'Anna (2010) chamam de "valor educação” e que Burgos (2012) explica do seguinte modo: “as autoras constatam que os pais do mundo popular, e especialmente as mães mais vulneráveis, conferem elevado valor à educação. Mas as escolas, afirmam as autoras, "parecem incapazes de valorizar esse capital social que é o valor atribuído à educação (p.1019). Esse "valor educação" que as famílias conferem aparece na fala de uma aluna da escola pública:

\footnotetext{
Eu, quando coloquei essa escola aqui na opção, como opção fiz porque todo mundo fala que essa escola é boa e tudo (...) Lógico a família fala porque foram eles que me deram apoio. A questão da família é essa...dar uma base legal, vai absorvendo as coisas boas, vai aprendendo, vai botar na escola pra ser alguém na vida” (Rede pública. Zona Sul. 2004).
}

Através da fala dessa aluna obtida em um grupo focal realizado em 2004, podemos identificar que a confiança na escola permanece desde a primeira pesquisa quando os dados de confiança na escola eram os seguintes: $55,3 \%$ dos alunos de escola pública tinham "muita" confiança e 29,3\% "alguma". Com relação aos jovens da rede particular, a porcentagem era de 55,1 com "muita" confiança e 40,3 com "alguma".

Outros estudantes das escolas públicas também se manifestaram com confiança na escola e relacionaram essa confiança a um valor introjetado e com expectativa do papel da educação para seu futuro. 
Vejamos algumas falas dos grupos focais realizados durante a primeira pesquisa e que comprovam essa visão otimista da educação.

"A escola é o caminho para o diploma, sem diploma a gente não tem nada (...) A escola é a base". (Rede pública. Tijuca. 2004).

Eu também acredito na escola. A escola é uma segunda família, porque na escola você não aprende só com os professores, você aprende com todas as pessoas" (Rede pública. Tijuca. 2006).

A visão otimista dos jovens com relação à escola também se estende para a universidade e podemos ver mais um aspecto da simetria entre esses jovens.

Gráfico 2.2

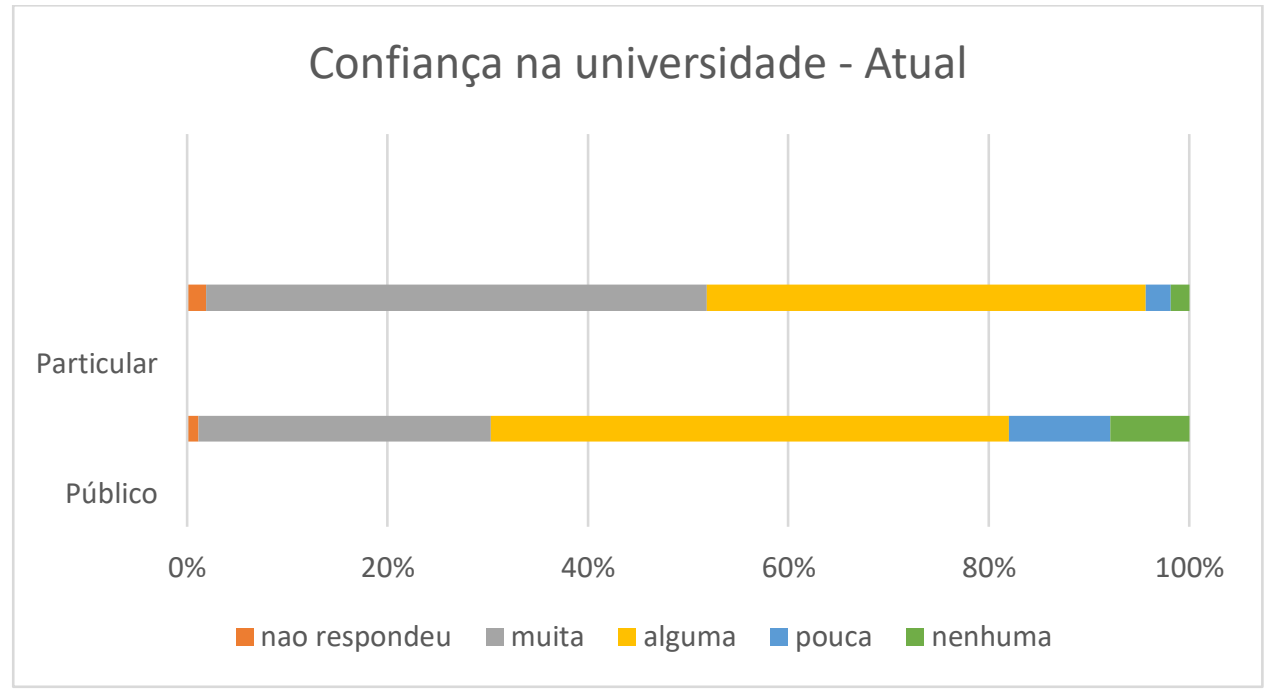

Ao construirmos o rótulo "visão otimista" e "visão pessimista" seguindo os mesmos critérios daqueles realizados com a confiança na escola, temos que 80,9\% dos jovens da rede pública tem uma visão otimista da universidade e $93,8 \%$ possuem a mesma visão, desta forma, detectamos aqui mais um ponto de simetria a qual, inclusive, também foi identificada na primeira pesquisa.

A universidade é uma das instituições que apresentam os maiores índices de confiança entre os jovens, mas existe uma observação importante a ser feita nesse momento. Embora entre os jovens da rede pública essa confiança seja alta, existe uma noção muito cara sobre as dificuldades que terão que enfrentar, caso desejem concorrer a uma vaga. Na fala de um aluno da rede pública estadual da Tijuca: 
Faculdade? Confio! Mas pra entrar numa faculdade pública tem que ter um estudo maior, sabe? Tem que ter um comprometimento, mas acontece que a gente não tem base pra nada na escola pública. Nós não temos base (...) Até pra fazer faculdade privada você tem que ter base. Tem que ter estudo e tem que ter dinheiro pra comprar livros, até na faculdade pública isso conta. Se for ver, a maioria das pessoas que estão na faculdade pública é da rede privada. Eles fazem preparatório o ano todo. A gente não tem isso. (Rede pública. Tijuca. 2006).

Essa visão crítica sobre o conteúdo que a escola pública oferece e o entendimento de que isso será um empecilho adicional, também aparece na fala a seguir:

O fato da gente estudar em colégio público também tem aquela competição com o pessoal do colégio particular. Por um lado, a gente tem uma preparação boa, mas não consegue competir porque a gente não tem como fazer um cursinho, então tem esse medo de competição (...) Esse pessoal que sempre estudou em colégio particular tem condições de ir pra faculdade, diferente do pobre coitado que estudou em colégio particular, aí chega um mauricinho e toma a sua vaga” (Rede pública. Barra da Tijuca. 2005).

A confiança dos jovens com relação à universidade também pode ser comprovada nas tabelas a seguir que apresentam a pretensão de realizar vestibular, sobretudo para universidades públicas.

\begin{tabular}{|c|c|c|c|c|c|c|c|c|c|}
\hline & & & Dad & da pes & quisa at & & & & \\
\hline & & vestit & & & & Que tip & de univer & sidade & \\
\hline & & Sim & Não & Total & & não sabe & Pública & Particular & Total \\
\hline Escola & Público & $88,8 \%$ & $11,2 \%$ & $100,0 \%$ & Público & $12,4 \%$ & $74,2 \%$ & $13,5 \%$ & $100,0 \%$ \\
\hline & Particular & $96,9 \%$ & $3,1 \%$ & $100,0 \%$ & Particular & $5,0 \%$ & $80,6 \%$ & $14,4 \%$ & $100,0 \%$ \\
\hline
\end{tabular}

Parece contraditório o fato dos jovens de escola pública, ao mesmo tempo em que apresentam um alto nível de confiança na escola (detectado na pesquisa quantitativa), no momento do grupo focal (apuração qualitativa) exponham avaliação bastante crítica sobre a má qualidade da educação oferecida ali que os colocam em uma situação de baixo padrão de competitividade para a conquista de uma vaga em uma universidade pública. No entanto, podemos interpretar essa situação não como contraditória, mas sim como uma expressão da noção crítica que esses jovens têm de sua realidade, fruto de seu grau de reflexividade.

Dois fatores podem nos ajudar na compreensão dessa situação. O primeiro é com relação ao "valor educação" e o segundo está no fato de a escola ser a única agência pública que mantém uma relação de longo prazo com o aluno e sua família (Burgos, 2012) ${ }^{33}$. Uma equação formada pelo "valor educação" e pela presença da escola enquanto agência pública

\footnotetext{
33 Burgos (2004) aponta que talvez, apenas a polícia consiga chegar de modo tão universal quanto a escola ao mundo popular.
} 
atuante, explicaria o resultado da elevada confiança. No entanto, os jovens não avaliam essa educação como "dádiva" ou "doação" do Estado e conseguem, por meio de uma análise bastante crítica, apontar as falhas do sistema educacional e interpretar as consequências dessa situação para suas vidas.

Os jovens, sejam de escola pública ou particular, avaliam a educação como uma via para a conquista de condições melhores de vida. A escola e a universidade estão entre as instituições que apresentam os maiores índices de confiança na primeira pesquisa e na atual. A educação surge em diversas falas que apresentam essa relação com um futuro melhor.

Deste modo, temos que, desde a primeira pesquisa, as simetrias com relação à confiança na escola e na universidade continuam, contudo existem situações sociais que se impõem e que diferenciam as perspectivas desses jovens com relação à educação. Enquanto os jovens da rede pública percebem, de modo crítico, que a escola pública não os habilita de maneira qualificada para uma vaga nas universidades públicas, os jovens da rede privada parecem viver sob a pressão dos responsáveis por meio de uma situação que chamaremos aqui de "noção da moratória social". Fica claro que esses jovens têm uma noção clara do investimento dos pais em seus estudos e isso acaba gerando certa ansiedade e uma expectativa para dar um "retorno ao investimento".

A “noção de moratória social” aparece de modo sistemático na fala desses jovens em três momentos dos grupos focais: 1) quando perguntados sobre a confiança na escola e na família, 2) quando perguntados sobre o que é ser jovem e 3) quando o assunto são os medos.

Durante algumas falas sobre a confiança na escola e na família, os jovens da rede privada muitas vezes se declaram como privilegiados e entendem que essa situação só é possível graças ao esforço dos pais em mantê-los em uma escola particular.

Meus pais estão garantindo pra mim e para o meu irmão uma boa oportunidade que é ter acesso a uma boa educação, em uma escola como essa e tem todo o mais que é o curso que a gente faz e tudo isso, pra lá e pra cá de carro, a gente não pega ônibus, então eu sei que é um esforço deles por mim e pelo meu irmão. (Rede privada. Zona Sul. 2019).

Quando expõem as agruras de ser jovem e ter que escolher uma carreira e mais que isso, ter que dar conta de conquistar uma vaga em universidade, a fala que demonstra a "noção da moratória social" também aparece.

A minha família é totalmente contra ofato de eu querer cursar cinema que é algo que eu gostaria muito de fazer. Eu entendo que a minha família é bastante conservadora então eles acham que se eu cursar isso, vou ser tipo...sabe?...pobre (...) a questão é que quando eu acabar a faculdade só vou depender de mim, e aí? (Rede privada. Zona Sul. 2019). 
Com relação aos medos, temos, mais uma vez, a presença dessa "noção da moratória social".

Meu maior medo hoje é não dar em nada. É olhar e ver que acabou a faculdade e que eu não dei em nada. Toda minha família olhando, e perguntando: e aí? E eu nada. (Rede privada. Zona Sul. 2019).

Os medos expostos pelos jovens também apresentam simetrias. Na primeira pesquisa os três maiores medos eram: ser vítima de violência, seguido pela incerteza com relação ao mercado de trabalho e, em terceiro lugar, o desemprego dos pais. O interessante a ser observado é que as porcentagens desses medos foram muito próximas ao que Edilaine de Andrade em seu artigo: "Juventudes: acesso à educação e ao mercado" interpreta por meio da análise de Novaes (2006) quando essa autora afirma que "atualmente os jovens, em geral, não conseguem alcançar melhores condições de trabalho que seus pais e, consequentemente, melhor qualidade de vida (...) e prossegue apontando as consequências que emergem dessa situação: "a diminuição das possibilidades de mobilidade social gera pessimismo e ausência de perspectiva em relação ao futuro” (Novaes, 2006 Apud, Andrade, 2013).

Quinze anos se passaram e esses medos permanecem como os principais, apesar da diferença na ordem “de importância”. Para os jovens da escola pública a "importância” dada aos medos aparece na seguinte ordem: desemprego dos pais/responsáveis (34,8\%), ser vítima de violência $(31,5 \%)$ e dificuldade com relação ao mercado de trabalho $(14,6 \%)$. Os jovens da rede particular apresentam os principais medos na seguinte ordem: ser vítima de violência $(39,4 \%)$, desemprego dos pais/responsáveis $(21,3 \%)$ e dificuldade com relação ao mercado de trabalho $(17,5 \%)$. Podemos entender que a permanência desses medos, expõe nossas desigualdades persistentes. Aqui podemos trazer o segundo "marco geracional" formulado por Novaes (2006) que é o medo da violência física. Para a autora:

O medo da morte expressa várias características da insegura vida atual, sobretudo nas metrópoles brasileiras, em que se concentram $31 \%$ dos jovens do país, mas também em outras cidades de médio porte. E, mesmo que nem sempre os jovens tenham sido atingidos diretamente pela violência urbana, o tema faz parte do imaginário socialmente construído. É um marco geracional importante. Entre os jovens de hoje há o temor expresso da morte prematura. (Novaes, 2006)

Ao consolidarmos as simetrias, temos que os jovens da rede pública e privada de nossa pesquisa se aproximam nas percepções sobre a confiança na família, na escola e na universidade. Enquanto os jovens da rede pública sofrem os constrangimentos gerados pela educação precária, os jovens da rede privada encontram-se diante das pressões para o "pagamento" da moratória social. Os medos também os aproximam, fazendo com que se encontrem na mesma calçada das consequências de uma desigualdade persistente. 
O maior volume de dados sobre as diferenças nas percepções dos jovens será visto no próximo capítulo, quando falaremos do conceito de cidadania, mas aqui é válido mostrar dados muito interessantes sobres quais são, no entendimento dos jovens, os maiores problemas brasileiros. A pergunta do questionário era: os três problemas brasileiros mais graves são: (enumere em ordem de importância).

Para expor esses dados, montamos tabelas com os principais problemas apontados pelos jovens de cada rede de ensino e organizados em ordem decrescente. As duas primeiras tabelas exibem os dados da primeira pesquisa, enquanto as outras duas os dados da pesquisa atual.

Tabela 3.0

\begin{tabular}{|c|c|}
\hline \multicolumn{2}{|c|}{ Primeira pesquisa } \\
\hline Problemas do país - rede pública \\
\hline Violência & $\mathbf{2 2 , 5 \%}$ \\
\hline Saúde pública & $\mathbf{1 7 , 4 \%}$ \\
\hline Desigualdade social & $\mathbf{1 2 \%}$ \\
\hline Pobreza & $\mathbf{1 0 \%}$ \\
\hline Corrupção & $\mathbf{9 , 8} \%$ \\
\hline Máqualidade de ensino & $\mathbf{7 , 7 \%}$ \\
\hline
\end{tabular}

\begin{tabular}{|c|c|}
\hline \multicolumn{2}{|c|}{ Primeira pesquisa } \\
\hline Problemas do país - rede particular \\
\hline Desigualdade social & $\mathbf{2 1 , 3 \%}$ \\
\hline Má qualidade de ensino & $\mathbf{1 5 , 6 \%}$ \\
\hline Corrupção & $\mathbf{1 5 , 0 \%}$ \\
\hline Violência & $\mathbf{1 4 , 9 \%}$ \\
\hline Saúde pública & $\mathbf{1 1 , 1 \%}$ \\
\hline Pobreza & $\mathbf{7 , 7 \%}$ \\
\hline
\end{tabular}

O resultado da primeira pesquisa trazia uma percepção completamente diferente sobre os problemas entre os jovens das duas redes de ensino, como é possível perceber a seguir. Enquanto para os jovens da rede pública os três principais problemas eram: violência, saúde pública e desigualdade social; para os jovens da rede particular os principais problemas eram: desigualdade social, má qualidade do ensino público e corrupção.

Os jovens da rede pública apresentavam como os dois principais problemas aqueles relacionados às suas experiências concretas cotidianas: violência e saúde pública. A presença da violência, em primeiro lugar, pode ser interpretada pelo fato desta ser um "marco geracional" importante (Novaes, 2001) e, ao mesmo tempo, um paradoxo historicamente inédito" (Novaes, 2006). Esse marco geracional, do qual falamos, representa um condicionante social que é uma experiência geracional comum, já o paradoxo historicamente inédito ocorre porque, ao mesmo tempo que a expectativa de vida da população em geral se amplia, também aumentam as taxas de homicídio de jovens, sobretudo negros e pobres.

Para os jovens da rede particular, os dois principais problemas encontravam-se em uma esfera mais abstrata: desigualdade social e a má qualidade do ensino público. 
Os dados obtidos pela pesquisa atual trazem uma nova dimensão sobre a percepção desses jovens com relação aos principais problemas do país.

Nas tabelas a seguir, apresentaremos os principais problemas divididos entre tipos de escola e organizados em ordem decrescente.

Tabela 3.1

\begin{tabular}{|c|c|}
\hline \multicolumn{2}{|c|}{ Pesquisa atual } \\
\hline Problemas do país - rede pública \\
\hline Corrupção & $18,0 \%$ \\
\hline Máqualidade de ensino & $10,1 \%$ \\
\hline Saúde pública & $9 \%$ \\
\hline Pobreza & $7,9 \%$ \\
\hline Desemprego & $7,9 \%$ \\
\hline Desigualdade social & $6,7 \%$ \\
\hline Impunidade & $6,7 \%$ \\
\hline
\end{tabular}

\begin{tabular}{|c|r|}
\hline \multicolumn{2}{|c|}{ Pesquisa atual } \\
\hline Problemas do país - rede particular \\
\hline Desigualdade social & $17,5 \%$ \\
\hline Má qualidade de ensino & $15,0 \%$ \\
\hline Corrupção & $13,1 \%$ \\
\hline Violência & $11,9 \%$ \\
\hline Racismo & $11,9 \%$ \\
\hline Saúde pública & $9,4 \%$ \\
\hline Desemprego & $5,0 \%$ \\
\hline
\end{tabular}

Enquanto os jovens da rede particular repetiram (exatamente) os três principais problemas, os alunos da rede pública reconfiguraram a lista trazendo para o topo a corrupção e a má qualidade do ensino público. Na primeira pesquisa, esses dois itens ficaram no final da lista com o $5^{\circ}$ e $6^{\circ}$ lugar respectivamente. Além disso, agora, aparecem na lista o "desemprego" e a "impunidade".

$\mathrm{Na}$ rede particular, os três principais problemas foram mantidos, mas chama atenção a presença de novos outros problemas como os principais do país, aparecendo, então, o racismo e o desemprego. É interessante observar que racismo e violência tiveram a mesma porcentagem, o que levantaria uma hipótese sobre a relação que os jovens fazem entre os dois problemas.

A subida da corrupção do $5^{\circ}$ para $1^{\circ}$ lugar, na passagem da anterior para a atual pesquisa, na percepção dos problemas do país apontados pelos jovens da rede pública pode ser analisado com ajuda dos dados obtidos pela organização não governamental Transparência Internacional ${ }^{34}$. Anualmente, essa Ong realiza uma pesquisa para identificar o “índice da percepção de corrupção" em 180 países.

Os índices de percepção da corrupção variam de 0 a 100, sendo 0 o pior nível, quando o país é percebido por seus cidadãos como extremamente corrupto, e, na outra ponta, o nível 100, que indica a percepção de altamente íntegro. De acordo com a Transparência Internacional, o Brasil apresenta uma aproximação constante do índice 0 desde 2012. Entre

\footnotetext{
34 Fonte: https://transparenciainternacional.org.br/
} 
2014 e 2015, passou do score 43 para 38, e entre 2016 e 2018, quando saiu do score 40 para 35. Atualmente, o score se mantém em 35.

Essa percepção sobre a corrupção tem causas muito profundas e vão além do esforço deste trabalho, mas é interessante notar como os jovens da rede pública se mostraram sensíveis a esse movimento a ponto de indicarem a corrupção como o pior problema do país. Talvez o aparecimento do item "impunidade" na lista dos problemas também esteja relacionado a esse contexto. Seguindo essa percepção sobre problemas do país, perguntamos aos jovens sobre a questão racial e o interessante a observar foi que, tanto os jovens da rede pública, quanto os da rede privada atrelam o preconceito racial e preconceito social. Cerca de $80 \%$ dos jovens afirma que a questão racial no Brasil é tanto racial quanto social. Uma possível interpretação sobre essa percepção dos jovens pode ser obtida a partir da reflexão de Carlos Haselbalg em Discriminação e desigualdades raciais no Brasil (2005) visto que, para esse autor essa "assimilação" nas percepções das questões raciais e de classe foram forjadas por mecanismos socioeconômicos e ideológicos construídos de modo a evitar altos níveis de antagonismo racial no Brasil. Dados obtidos nos grupos focais poderiam ter nos ajudado a validar melhor essa hipótese, apesar disso, entendemos que esse é dado não poderia deixar de ser apresentado, visto que, expõe uma percepção importante dos jovens.

\begin{tabular}{|l|r|r|r|r|}
\cline { 2 - 5 } \multicolumn{4}{|c|}{} & \multicolumn{2}{c|}{ Dados da pesquisa atual } \\
\hline \multicolumn{3}{|c|}{ Quanto a questão racial no Brasil, em sua opinião } \\
\hline & $\begin{array}{c}\text { Não há } \\
\text { preconceito } \\
\text { racial, mas } \\
\text { sim social }\end{array}$ & $\begin{array}{c}\text { Vivemos } \\
\text { numa } \\
\text { democracia } \\
\text { racial }\end{array}$ & $\begin{array}{c}\text { Há } \\
\text { preconceito } \\
\text { tanto racial } \\
\text { quanto } \\
\text { social }\end{array}$ & $\begin{array}{c}\text { Há } \\
\text { preconceito } \\
\text { racial }\end{array}$ \\
\hline Público & $2,2 \%$ & $3,4 \%$ & $78,7 \%$ & $15,7 \%$ \\
\hline Particular & $0,0 \%$ & $1,3 \%$ & $83,8 \%$ & $15,0 \%$ \\
\hline
\end{tabular}




\section{3}

\section{A historicidade do conceito de cidadania}

Após identificarmos as simetrias, ou seja, os temas que aproximam as percepções dos jovens apesar de suas realidades distintas, apresentaremos os dados que demonstram as desigualdades que transbordam da percepção dos jovens de nossa pesquisa, mas antes desses dados, é necessário mostrar de que perspectiva teórica vamos abordar outro eixo de análise central da pesquisa, a cidadania.

Para a realização desse percurso, aplicaremos a mesma estrutura de desenvolvimento utilizada na primeira etapa, quando abordamos o conceito de juventude. Assim sendo, partiremos do repertório teórico reconhecido como fundante da teoria social acerca do conceito de cidadania e "ajustando o foco" para a dimensão deste conceito no contexto brasileiro para, ao final, relacioná-lo aos dados da nossa pesquisa, no que diz respeito às percepções dos jovens sobre o tema.

As transformações sociais ocorridas, sobretudo, nas sociedades europeias, ao longo do século XVIII, XIX e XX, produziram a complexificação das relações sociais. O modelo de sociedade estamental, baseado na aristocracia, na agricultura, na ausência de mobilidade e na servidão, perdeu espaço para a sociedade industrial. Esse processo econômico veio acompanhado por grandes transformações políticas, quando nova ontologia do social produz a ruptura daquela ordem tradicional. Entra em cena as ideias de liberdade, igualdade $e$ fraternidade.

Thomas Humphrey Marshall em sua obra Cidadania, Classe Social e Status, analisa esse conjunto de transformações que foram responsáveis por transformar as relações sociais, a partir do contexto inglês ao longo dos séculos XVIII, XIX e XX e constrói uma abordagem que credita a cada século um conjunto de transformações responsáveis por forjarem novos padrões de relação entre o Estado e a sociedade. Ou seja, para Marshall, a sociedade inglesa foi capaz de avançar na conquista de espaço na esfera pública e de direitos gradualmente a partir do século XVIII. Na sua visão otimista do pós-guerra, Marshall via a conquista de direitos como um ideal a ser cumprido para se atingir o status de cidadania.

A partir da obra de Marshall, o tema da cidadania ganha um espaço central nas Ciências Sociais, fazendo deste autor um dos mais citados, tanto na área de Sociologia, quanto de Ciência Política.

Contudo, a forma como Marshall organizou as "etapas" ou "estágios" para a construção dos direitos na Inglaterra, dividida por séculos, gerou uma série de críticas, fazendo com que o conceito de cidadania ganhasse centralidade na sua relação com o Estado- 
nação, ou seja, como cada Estado foi estabelecendo marcos legais na direção da fruição dos direitos $^{35}$.

De acordo com Marshall, os direitos de cidadania surgiram no período da modernidade a partir da formação dos Estados nação que representaram a fragmentação institucional dos antigos estamentos do período medievo. Esses direitos, na Inglaterra, teriam se desenvolvido em uma sequência de etapas "evolutivas", partindo dos direitos civis, passando pelos direitos políticos e finalmente chegando aos sociais.

Na visão de Marshall, a construção tipológica dos direitos estaria claramente relacionada aos acontecimentos sociais de cada século correspondente. Em suas palavras:

\begin{abstract}
Quando os três elementos da cidadania se distanciam uns dos outros, logo passaram a perceber elementos estranhos entre si. O divórcio entre eles era tão completo que é possível, sem distorcer os fatos históricos, atribuir o período de formação da vida de cada um a um século diferente - os direitos civis ao século XVIII, os políticos ao XIX e os sociais ao XX". (p.66)
\end{abstract}

Deste modo, a cidadania para Marshall está baseada em um conjunto de ideais, crenças e valores. Ele a define como um status adquirido, o qual deve ser reconhecido por todos os membros integrantes de uma comunidade. Isso significa dizer que todo indivíduo é detentor de status de cidadania, tendo a garantia de igualdade no trato dos direitos e obrigações.

Importante realçar este detalhe de sua obra, segundo o qual o status da cidadania não estaria em apontar a igualdade que decorre do padrão de vida em termos quantitativos, ou seja, econômico, financeiro ou de renda, mas em termos qualitativos, o que implica em dizer numa condição de vida conforme um padrão tido por civilizado, o que significa liberdade, segurança, bem-estar, prosperidade, felicidade. (Marshall, 1967, p. 61). ${ }^{36}$

Nesse sentido, o ponto central da reflexão de Marshall e sua contribuição acerca do estudo sobre a cidadania é que, embora deixe claro que não exista uma forma predeterminada e universal acerca de como os direitos e deveres são formados e se aplicam em cada sociedade, ela assume um significado específico e inconfundível que consiste numa condição de igualdade social de participação na vida em comunidade. Isso nos leva a afirmar, baseando-se em suas reflexões, na existência de uma determinante contida no significado de

\footnotetext{
35 Apesar de ter realizado seu estudo sobre cidadania focado no sistema social inglês, a atualidade de Marshall consiste em ter "organizado" a análise sobre os direitos e sua conquista em períodos históricos divididos.

36 Mais precisamente, Marshall vai colocar a questão sobre padrões de vida enquanto dimensão "qualitativa da vida como um todo em termos dos elementos essenciais na civilização ou cultura", indicando que o significado dessa dimensão qualitativa é o que corresponderia à condição de participação na sociedade, "como membros completos da sociedade, isto é, como cidadãos" (1967, p.62).
} 
cidadania, tendo em vista essa ideia de igualdade enquanto pertencimento e participação caracterizadora da condição do que seja ser cidadão.

Assim, cada sociedade desenvolve uma imagem ideal, geralmente baseando-se em algum modelo existente, ou seja, tomando como referência alguma sociedade que tenha se aproximado da realização completa da cidadania e segue um caminho equivalente. As aspirações de cada sociedade, neste caminho de busca por modelos de cidadania, têm como foco a igualdade e a ampliação do número de indivíduos que desfrutam do status.

Segundo Marshall, o crescimento da cidadania coincide com o desenvolvimento do sistema capitalista e sua questão central é tentar entender "como é possível que estes dois sistemas opostos possam crescer e florescer, lado a lado, no mesmo solo?", ou ainda, "o que fez com que eles se reconciliassem e se tornassem, ao menos por algum tempo, aliados ao invés de antagonistas?" (p.76).

Temos, assim, o pilar da liberdade e o da igualdade, que são bases da cidadania, emergindo concomitantemente com a desigualdade, que é produto da exploração do sistema capitalista desde a Revolução Industrial no contexto da Inglaterra.

A equação está posta: liberdade, igualdade e sistema capitalista. Ou melhor, cidadania e desigualdade. Como resolver? A primeira pista de Marshall está na importância do contexto.

Quando se percebe que a cidadania é formada de acordo com cada contexto nacional, entende-se a necessidade de analisarmos este conceito sem perder de vista as peculiaridades políticas e sociais de cada país. Percebemos a importância de uma análise comprometida com cada realidade e, principalmente, nos damos conta de que cidadania deve ser sempre contextualizada sob o risco de incorrermos no erro de tentar transformá-la em um conceito vazio.

No contexto da Inglaterra, por exemplo, a relação entre cidadania e desigualdade formou uma equação que deveria ser resolvida a partir desses mesmos elementos. Explico melhor. Se em um primeiro momento a noção de liberdade serviu ao sistema capitalista, por meio da oferta de mão de obra livre, num segundo momento, a desigualdade gerada por essa situação serviu de estopim para a luta por direitos.

O primeiro direito civil (de acordo com a tipologia de Marshall) a ser assegurado por lei, na Inglaterra, a partir do século XVIII, foi a liberdade individual.

A liberdade individual abriga a liberdade à propriedade, à justiça, a liberdade de expressão e de religião. De acordo com Marshall, a liberdade assegurada por lei é a base que sustentará todos os direitos que serão conquistados nos próximos séculos. Em suas palavras: 
"a história dos direitos civis em seu período de formação é caracterizada pela adição gradativa de novos direitos a um status já existente e que pertencia a todos os membros adultos da comunidade" (p.68).

A partir do século XIX, o direito à liberdade individual foi sendo gradualmente reconhecido, e, na visão de Marshall, essa situação é a que vai possibilitar a conquista dos direitos políticos.

Embora a liberdade fosse uma realidade normatizada, os direitos políticos só eram acessados por uma parcela restrita da população. Para Marshall, "está claro que, se sustentarmos que, no século XIX, a cidadania na forma de direitos civis era universal, os direitos políticos não estavam incluídos nos direitos de cidadania. Constituía o privilégio de uma classe econômica limitada cujos limites foram ampliados por cada Lei de Reforma sucessiva". (p.70).

É importante ressaltar aqui que os direitos políticos já existiam, mas de forma restrita. O que marcará o século XIX como o século da conquista dos direitos políticos é a ampliação da esfera política para a participação de mais indivíduos. Segundo Marshall: Os direitos políticos não representam a criação de novos direitos, mas a ampliação "de velhos direitos a novos setores da população ${ }^{37 "}$

A narrativa de Marshall nos permite entender que, apesar dos avanços ocorridos em relação à obtenção dos direitos civis, enquanto "status geral de cidadania", os direitos políticos, no século XIX, ainda representavam um obstáculo para enormes parcelas da população, tendo em vista que estavam circunscritos a uma classe privilegiada por questões de natureza econômica (1967, p. 69).

Como nos revela o autor, o princípio da cidadania política universal somente será reconhecido como categoria universal, na Inglaterra, mediante a introdução da lei naquele país que adotou o sistema do sufrágio universal, em 1918, ou seja, no início do século XX, embora seja o século XIX o marco temporal destes direitos, ressaltando, assim, que:

\footnotetext{
Foi, como veremos, próprio da sociedade capitalista do século XIX tratar os direitos políticos como um produto secundário dos direitos civis. Foi igualmente próprio do século XX abandonar essa posição e associar os direitos políticos direita e independentemente à cidadania como tal.
}

Prosseguindo em sua análise, o autor faz uma importante advertência: "mas a lei de 1918 não estabeleceu, por completo, a igualdade política de todos em termos de direitos de cidadania" (1967, p.70), evidenciando que a condição de igualdade básica de participação na

\footnotetext{
37 De acordo com Marshall, em 1832, os eleitores ingleses somavam menos de um quinto da população masculina adulta.
} 
vida comunitária, noção que é o substrato do seu conceito de cidadania, carecia de uma preocupação que estava ligada aos chamados direitos sociais.

Cabe enfatizar que Marshall possui uma visão otimista quanto aos direitos sociais, não no sentido que possuíam no século $\mathrm{XIX}^{38}$, mas conforme o significado assumido no século XX, quando a noção de igualdade social contida no status de cidadania representará uma forma de enfrentamento da desigualdade (1967, p. 88).

Os direitos sociais, assim, adquirem um "novo sentido" através da adoção de diversas medidas interventivas do Estado na sociedade, como, por exemplo, programa de distribuição de renda, sistema de impostos diretos progressivos e produção voltada ao mercado interno, ou seja, uma nítida preocupação com as classes menos favorecidas, o que teria diminuído a distância entre as classes, entre o capitalista e o proletariado. Na compreensão de Marshall, essas alterações e mudanças provocaram modificações também no padrão da desigualdade social.

Notadamente, é significativo que os direitos sociais deixam de representar um estigma ou marca pejorativa para assumirem um avanço na direção da igualdade social, já como uma marca positiva, ou seja, não bastava ser detentor de uma igualdade em termos de direitos individuais, ou participar do processo político, havia, agora, uma busca por condições materiais civilizatórias enquanto herança cultural, da qual todos estão integrados e sentemse pertencentes, como dirá o autor. Está aí o novo sentido dos direitos sociais e a sua contribuição em relação aos direitos civis e políticos.

Além disso, ele destaca o papel desempenhado pela educação, que ocupa lugar específico entre os direitos de cidadania, pois ela atravessa todas as faixas etária para se apresentar como condição para a formação plena do cidadão. Analisando a relação entre Estado, Educação e Cidadania, Marshall expõe que

a educação das crianças está diretamente relacionada com a cidadania, e, quando o Estado garante a todas as crianças serão educadas, este tem em mente, sem sombra de dúvida, as exigências e a natureza da cidadania. Está tentando estimular o desenvolvimento de cidadãos em formação. $\mathrm{O}$ direito à educação é um direito social de cidadania genuíno porque o objetivo da educação durante a infância é moldar o adulto em perspectiva. Basicamente, deveria ser considerado não como o direito da criança frequentar a escola, mas como o direito do cidadão adulto ter sido educado" (1967, p. 73).

Quem também ajuda nessa discussão a partir de uma perspectiva histórico-comparada é Reinhard Bendix, que em sua obra "Cidadania e Construção Nacional”, complementa as

\footnotetext{
38 Segundo Marshall, a Poor Law representava o divórcio entre os direitos sociais e o status de cidadania, pois aqueles exprimiam uma ideia de indigência, condição que retirava a capacidade de ser livre e participar das decisões políticas em condições iguais, ou seja, uma condição de não cidadania. Todo indivíduo submetido a Poor Law “abriam mão, na prática, do direito civil da liberdade pessoal devido ao internamento na casa de trabalho, e eram obrigados por lei a abrir mão de quaisquer direitos políticos que possuíssem. (1976, p. 72).
} 
análises de Marshall ao enfatizar a importância da análise da extensão da cidadania à classe trabalhadora.

Ambos os autores escrevem suas teses sobre cidadania em meados do século XX, apontam para a importância da ideia de direitos e obrigações na construção nacional na sociedade industrial. No entanto, o modo como vão contextualizar o aparecimento da cidadania se apresenta bem distinto, pois Bendix parte de Tocqueville e Weber para trazer a questão dos dilemas postos entre as promessas de igualdade e liberdade com a produção de desigualdade nas sociedades capitalistas. O próprio Bendiz assinala que sua abordagem tem como base inicial a obra de Marshall, mas procura ir além, quando traz para a discussão do problema da extensão da cidadania às classes baixas da Europa Ocidental em geral, e à Inglaterra em particular e de que modo os contextos nacionais que analisa produzem acordos específicos para a realização dos direitos.

A perspectiva de Bendix amplia o campo e o horizonte de análise sobre o fenômeno da cidadania, na medida em que observa que o motor das transformações sociais não está apenas numa dimensão material ou econômica, mas nas próprias estruturas políticas, ou seja, institucionais de poder, organização e comando.

A tese central de Bendix consiste em demonstrar que a conquista dos direitos não ocorre por uma simples relação de causa e efeito, na qual, a causa seria o industrialismo moderno e a consequência, a cidadania nacional, ou seja, para esse autor não se pode atribuir ao processo de industrialização o desenvolvimento dos direitos de cidadania. Embora na Inglaterra esses fenômenos tenham ocorrido de forma "próxima", são indubitavelmente, processos distintos. Essa tese de Bendix será importante por dois motivos: i) irá demonstrar que para cada Estado-nação haverá uma "cronologia" própria para a construção dos direitos e ii) os grandes responsáveis pela construção dos direitos foram as demandas das classes mais baixas, sobretudo os trabalhadores.

Para Bendix, cada país constrói um tipo peculiar de cidadania, sendo a maneira como cada um conduzirá a extensão e universalização desses direitos às classes inferiores o aspecto mais relevante para se identificar as características de cada um deles. Nas suas palavras:

\footnotetext{
"A extensão de vários direitos às classes baixas constitui o desenvolvimento característico de cada país (...) Uma consideração detalhada de cada um desses desenvolvimentos notaria o considerável grau com que os decretos-lei são negados ou violados na prática. Ela sublinharia, portanto, como a questão da posição cívica das classes baixas era enfrentada ou burlada em cada país, quais alternativas políticas estavam em estudo, e quais os passos sucessivos que conduziram finalmente à extensão dos direitos de cidadania" (p.114).
} 
A maneira como se organizará a relação entre o Estado e as classes mais baixas determinará o modo como a cidadania será construída, por isso, o autor se empenha em identificar e descrever as mobilizações dessa parcela da população e com isso vai mapeando a forma como os direitos foram conquistados.

Inicialmente, Bendix descreve como as relações da sociedade estamental vão se transformando à medida que as classes mais ricas vão deixando de aceitar as responsabilidades com os pobres. E, essa situação é agravada no período inicial da industrialização, momento no qual diversos teóricos passam a defender uma posição contrária à questão da caridade, sustentando que os indivíduos mais pobres devem se esforçar mais no trabalho a fim de evitar o comodismo e a indolência.

De acordo com os teóricos da época, somente através de grande esforço e trabalho é que o indivíduo teria sua recompensa, indicando sua valorização na sociedade. Tais teóricos dividiram os fundamentos da não responsabilidade aristocrática em três partes complementares, conforme relata Bendix. Primeiramente, surge a ideia de que a caridade é prejudicial aos mais pobres porque destrói a vontade de trabalhar e, dessa forma, intensifica a pobreza. Além disto, é responsável pelo aumento da indolência, porque o pobre se acomoda ao saber que alguém virá em seu socorro. Por isso, mesmo que o rico queira não poderá ajudar ao pobre porque este deve aprender a ser autossuficiente.

A segunda teoria se baseava na teoria do mercado. Dentro dessa perspectiva, a mãode-obra era um produto como outro qualquer, estando orientado pelas leis da oferta e da procura. $\mathrm{O}$ trabalhador deveria se empenhar ao máximo para fugir da fome, a qual funciona como uma espécie de "estímulo", ou seja, para não passar fome, a única saída do trabalhador é o seu empenho máximo ao trabalho. Identificada com a obra de Malthus, a terceira ideia relaciona a teoria de mercado com a teoria da população. Para seus formuladores, a população cresce mais rapidamente que os meios de subsistência e, contra essa situação, as classes superiores não têm como intervir, visto que a pobreza é inevitável devido ao crescente número de indivíduos.

Todas essas teorias mencionadas convergiram para a questão do esforço individual como meio de alcançar a dignidade e o autorrespeito. Contudo, o indivíduo oriundo das classes baixas não tinha condições mínimas para transformar seu estado socioeconômico.

Assim sendo, tornou-se necessária a criação de uma base sobre a qual todos os indivíduos teriam as mesmas oportunidades de alcançar o status. Ao disporem do instrumento essencial, acreditava-se que apenas lhes restaria seu esforço próprio. Essa "base" passou a 
ser a educação, a qual era vista como "a única forma de combater a imprevidência e a ignorância que resultavam em falta de restrição moral". (p.95)

A partir desse momento, a educação passa a ser o foco central das discussões na época e único instrumento do trabalhador, dependendo apenas de si próprio. Em outras palavras, a educação passa a ser vista como fonte de mérito pessoal, ou seja, o homem que soubesse aproveitar essa oportunidade, primeiro, conseguiria se livrar de sua baixa condição econômica, depois, estaria habilitado a participar da esfera pública, conquistando, por fim, o status de cidadania.

Essa transformação na concepção do indivíduo pobre como único responsável pela transformação de sua condição gera uma divisão entre pobres diligentes e pobres imprevidentes. Isto porque todo indivíduo que não consegue "subir na vida" é visto como imprevidente, porque lhe foi dada a oportunidade da educação, mas ele não soube aproveitar a oportunidade, provavelmente, porque se rendeu aos vícios e à indolência.

Para Bendix, essa construção do mérito com base na vontade e no empenho de cada indivíduo constituirá uma ideologia de extremo impacto sobre a condição social e consciência política do trabalhador, tendo em vista que:

\begin{abstract}
o elogio a bons hábitos e ao trabalho árduo conduz por si mesmo a julgamentos hostis de um teor muito provocativo. O trabalhador bom e honesto é um modelo a ser seguido como distinto do trabalhador preguiçoso e imprevidente, cujas eficiências são difundidas pelo rádio, em benefício de todos os que ouvirem e como um aviso que provoca desprezo e condenação. A maneira pública pela qual esses “atributos coletivos" são discutidos transforma-os em questão política (p.97).
\end{abstract}

Essa concepção individualista, a qual impõe ao trabalhador que, para conquistar uma melhor posição econômica e ser reconhecido na sociedade, deve ser esforçado e disciplinado em seu trabalho, é desenvolvida principalmente no período da industrialização, período no qual a mão-de-obra é a matriz da produção econômica. Contudo, o sistema capitalista não facilita a ascensão econômica desses trabalhadores que, apesar de todo esforço, permanecem “engessados" em suas condições econômicas e sociais. Deste modo Bendix observa que:

\begin{abstract}
A interpretação individualista das relações de autoridade na indústria aparece, deste ponto de vista, como um esforço para negar os direitos de cidadania àqueles que são malsucedidos economicamente, uma abordagem que pode despertar um novo sentido do direito por parte das classes inferiores e conduzir a esforços tateantes para definir a posição dessas classes na comunidade política nacional” (p. 97).
\end{abstract}

Apesar desse contexto que parece sufocar materialmente e ideologicamente os trabalhadores, estes reunirão condições para tomada de consciência e engajamento em prol da luta pela conquista de direitos. Na ótica de Bendix essa "tomada de consciência" dos trabalhadores ocorreu devido a uma confluência de fatores, tais como: “(...)a alfabetização dos trabalhadores, a divulgação do material impresso entre eles, a concentração física dos 
trabalhadores, a maior mobilidade geográfica e a despersonalização do relacionamento no emprego" (p.99). E, utilizando as palavras de Mannheim, Bendix conclui que "A sociedade industrial moderna por mobilizar física e intelectualmente o povo incita a ação das classes que antigamente só desempenhavam um papel passivo na vida política" (p.99).

A partir daí, é colocado em marcha um movimento que representa o esforço dos operários em garantirem, digamos, uma posição que imponha respeito e a possibilidade de serem habilitados e ouvidos nos conselhos nacionais, a fim de garantir seu espaço dentro de seu Estado-Nação, o que compensava, segundo Bendix:

(...) o sentimento de injustiça entre os trabalhadores, sua perda do autorrespeito, o abuso pessoal que os dirigentes da sociedade cumulam sobre eles, o movimento cartista como expressão do ultraje da gente do povo à negação de seus direitos civis, e o entendimento dos trabalhadores de serem uma classe proscrita em seu próprio país" Através da percepção de que "o trabalho é a pedra angular sobre a qual a sociedade civilizada é construída". (p.102)

Surge então, um problema crítico: como ajustar todo protesto social das classes mais baixas à cidadania, ou seja, como realizar todas as expectativas, reivindicações dessa classe e colocá-las em prática?

Esse processo de mobilização das classes trabalhadoras, aponta Bendix, revela que "mais do que comprometer-se com uma busca de uma nova ordem social, as massas recentemente politizadas protestam contra sua cidadania de segunda classe, exigindo o direito de participação em termos de igualdade na comunidade política do Estado-Nação"(p.109)

Compreende-se, assim, que a ideia de "participação em termos de igualdade na comunidade política do Estado-Nação" significava que os indivíduos não tinham como objetivo romper com a ordem social vigente, mas serem incluídos nela: desejavam ser tratados como iguais, sem distinção econômica; requeriam o direito de estabelecer contratos em igualdade; pretendiam adquirir e dispor de propriedade e participar ativamente da vida política. Com base na narrativa de Bendix, pode-se dizer que essas transformações sociais e políticas desencadearam uma nova condição do indivíduo na sociedade, já que todos os homens passavam a ser orientados pelas mesmas leis. Importante dizer que nada era feito em relação à capacidade de cada indivíduo em usá-la. Constitui-se, assim, a igualdade nas leis e a desigualdade na sua fruição.

A aproximação das perspectivas entre Marshall e Bendix quanto ao desenvolvimento da cidadania pode ser aqui destacado, permitindo um diálogo entre esses autores, pois ambos assinalam que a conquista da condição de igualdade foi um marco importante para o desenvolvimento dos direitos fundamentais que formam a noção de cidadania. Enquanto Marshall vê na liberdade individual a condição para a busca de uma igualdade cada vez 
maior, na sequência lógica dos direitos civis, políticos e sociais, Bendix mostra que tal liberdade não tornou possível a igualdade, senão que aguçou na classe trabalhadora um direito de reivindicar politicamente seu devido reconhecimento e pertencimento na unidade integral nacional, ao se considerar como força social produtora de riqueza.

Prosseguindo nesse diálogo, assim como Marshall, Bendix analisa que somente quando ultrapassado aquele primeiro momento, no qual a igualdade perante a lei deixa de ser um sinônimo apenas de liberdade de contrato, é que ela assumirá um princípio significativo para a posse de direitos políticos e sociais. Explico melhor: os autores observam que, inicialmente, por mais contraditório que pareça, os direitos sociais eram válidos apenas para os considerados como "não cidadãos", ou seja, indivíduos que não tinham condições de se engajar no esforço econômico como, por exemplo, as mulheres e as crianças. Em outras palavras, cidadãos eram apenas aqueles que contribuíam economicamente com o país e, para estes, qualquer tipo de benefício era negado porque deveria ser estimulada sua independência e autonomia. Os homens trabalhadores não deveriam exigir nenhum benefício, caso contrário, colocariam sua autonomia e liberdade em risco. Assim, para Marshall, foi necessário que a noção de igualdade se universalizasse a partir da compreensão da condição de ser livre. Por outro lado, Bendix vai observar que a ideia de liberdade vai se traduzir em participação política para a obtenção de condições de igualdade e pertencimento na comunidade nacional.

Um ponto de diálogo e complementariedade entre eles está na questão da importância da educação como direito social básico; para Marshall, ela é um pré-requisito para a cidadania, enquanto para Bendix ela é um meio de integração social, pois faz com que o Estado, garanta um mínimo de igualdade inicial entre os indivíduos.

Gradativamente, os indivíduos, em sua maioria trabalhadores das indústrias, foram conquistando direitos, como o de associação, que foi um dos primeiros direitos a serem conquistados no século XVIII. Na verdade, retomando aos apontamentos de Bendix, é com a formação das associações de trabalhadores que surgem os primeiros sindicatos. Contudo, problematiza que esse direito, por um lado, representava uma tentativa de buscar a igualdade, mas, por outro, acabava gerando desigualdades, pois ele acredita que o direito de associação é uma demonstração clara da "inabilidade dos trabalhadores de salvaguardar seus interesses individualmente". Segundo o autor, os sindicatos funcionavam como uma forma dos trabalhadores se unirem para reivindicar seu status dentro da sociedade, ou seja, "os trabalhadores se organizam a fim de atingir o nível de recompensa econômica ao qual se sentem no direito", ou seja, o papel dos sindicatos era o de "levantar a posição econômica de 
seus membros". (p.120), ainda que ele aponte os traços corporativistas desde os primeiros sindicatos.

Na perspectiva de Bendix, os direitos civis seriam facultativos, e não obrigatórios, pois pondera que as práticas associativas dos sindicatos violaram esta regra, transformando a participação em uma condição habilitadora para a obtenção dos direitos, ou seja, o direito civil foi utilizado para habilitar as classes baixas ao acesso a seus direitos. Partindo da análise da construção histórica da conquista do direito universal do voto e fazendo uma tipologia dos vários tipos de voto, Bendix mostra o caminho do voto censitário ao universal e enfatiza a importância da análise de cada contexto nacional no caminho de sua universalização. O ponto mais importante desta análise de Bendix é a de que ele percebe que "os passos escolhidos para chegar ao cume do processo que se daria através do voto universal variam marcadamente de país para país e refletiram diferenças básicas nos valores e características dominantes de cada estrutura social" (p.125).

Voltando à questão do direito à educação, este é um ponto de encontro comum entre os autores, que para eles está na questão do direito à educação. Importante frisar que se para Marshall a educação é um direito social, era também um pré-requisito para a cidadania; para Bendix ela funciona como condição para a integração social. Assim sendo, afirma que ela funciona como condição para a integração social e sua análise se concentra no momento em que a educação se tornou um dever de cidadania em quase todos os países da Europa Ocidental, permanecendo como um mínimo prescrito em lei, ainda que em momentos nos quais as atribuições do Estado estejam reduzidas.

O interessante a ser ressaltado neste ponto é que a ideia em favor da extensão da educação básica a todos não depende de ideologia: por exemplo, os liberais que afirmam que a educação é uma das únicas atribuições do Estado, os socialistas que estimulam os trabalhadores a exigirem este direito como fonte de emancipação e finalmente os conservadores que acreditam que a educação possa refrear o inerente desgoverno do povo.

Assim, finalmente a educação deixa de ser exclusiva de uma determinada classe e passa a ser um dos elementos mais importantes que compõem a cidadania, entendida como uma espécie de alicerce dos demais direitos, ou ainda, como elemento básico, sem o qual os outros passam a ser obsoletos. A importância da educação como direito e como dever passa a ser defendida pelas mais diferentes correntes ideológicas do século XX.

A contribuição que Bendix traz ao nosso trabalho são as transformações sociais que ocorrem até que todos os indivíduos, independentemente de qualquer requisito econômico ou social, tenham abertura para participação política e para a obtenção de seus direitos; 
refere-se à questão dos direitos como meio de promover igualdade, ao mesmo tempo em que acaba, por outro lado, produzindo novas formas de desigualdade. Este fato impõe que os indivíduos estejam sempre formulando mecanismos para corrigir as desigualdades, daí a importância da educação como meio para integrar socialmente e possibilitar a participação e intervenção consciente dos cidadãos nos debates públicos.

\section{1}

\section{Dilemas da cidadania no Brasil}

Tendo entendido que cada sociedade, em diferentes contextos históricos e políticos constroem uma relação específica de cidadania, cabe, neste momento, trazer esta dimensão de sua construção para o Brasil para, nos perguntar como ela se realizou aqui e quais são suas características peculiares e, ainda, quais foram os aspectos mais relevantes que marcaram sua formação E que nos ajudam a compreender a questão da desigualdade na fruição dos direitos. Tal análise ajudará na interpretação dos dilemas da educação como direito social.

Segundo José Murilo de Carvalho em seu livro Cidadania no Brasil: o longo caminho, a cidadania "virou gente", ou seja, esse conceito foi apropriado de tantas maneiras diferentes que, em determinadas situações, parece ter ganhado vida e até mesmo vontade própria. Nos discursos dos políticos a cidadania parece um sonho, um prêmio ou um alvo de conquista, numa abordagem policial o indivíduo, por assim dizer, "portador" da cidadania, ou seja, cidadão é muitas vezes chamado desse modo com certo ar pejorativo e desqualificador.

Para analisarmos esse conceito nos apoiaremos nas análises de alguns dos principais autores que descrevem com propriedade as características particulares de nossa sociedade e para isso, dividiremos três grupos de autores por três períodos históricos distintos. Deste modo, nosso percurso analítico será o seguinte:

i) Do Império à Primeira República, com o apoio do repertório teórico de Robert Schwarz (1992), Sérgio Buarque de Holanda (1982) e José Murilo de Carvalho (1987). Em seguida, ii) Do final da primeira República até a ditadura militar, mostrando o processo de complexificação das relações sociais e consequentemente do conceito de cidadania com Elisa Reis (1998), Wanderley Guilherme dos Santos (1979) e, mais uma vez, José Murilo de Carvalho,(1991), e finalmente iii) O período de redemocratização e o agravamento de nossas desigualdades pelos olhares de Maria Alice Rezende de Carvalho, Vera da Silva Telles (1994) e Evelina Dagnino (1994). Nosso objetivo será o demonstrar que a cidadania é um conceito que requer atenção constante à dimensão do contexto histórico social, como enfatizado por Bendix, e que as desigualdades sociais persistentes impactam diretamente nesse processo. 
O período colonial, de acordo com Sérgio Buarque de Holanda, será o responsável por deixar uma marca profunda na sociedade brasileira, o que esse autor denomina de "herança rural”, isso significa dizer que “(...) da riqueza que se funda no emprego do braço escravo e na exploração intensiva e perdulária das terras da lavoura" se obtinha o único modo de vida (Holanda, 1995 p.74). Essa marca de origem, ou melhor, essa herança será a responsável por cunhar características que estarão presentes ao longo de toda história brasileira e que serão responsáveis pelas características mais contundentes de nossa cidadania.

O engenho pode ser interpretado como o primeiro "microcosmo" da sociedade brasileira. Essa estrutura que se desenvolvia em torno da "casa grande”, da lavoura de açúcar, da capela e da senzala, perdurou do período que vai do Brasil Colônia ao fim do Império, em 1889 e nas palavras de Holanda: "o engenho constituía um organismo completo e que, tanto quanto possível, se bastava por si mesmo. (Holanda, 1992.p.80). Apesar de termos alcançado a independência em 1822, a estrutura de organização econômica-social com base no latifúndio, na monocultura para exportação, no patriarcalismo e no trabalho escravo, em pouco ou nada se alterou a organização social. Como aponta Roberto Schwarz: “como é sabido, éramos um país agrário e independente, mas dividido em latifúndios, cuja produção dependia do trabalho escravo por um lado e por outro do mercado externo" (Schwartz, 1992 p. 14).

Esses "microcosmos" formados pela estrutura econômica e social dos engenhosinviabilizavam a ruptura em direção à construção de relações sociais em que o elemento fundante seria o indivíduo portador de direitos. Todas as relações sociais, políticas e econômicas eram dominadas pelos senhores de engenho e grandes fazendeiros que ditavam as regras de acordo com seus mandos, o que constrangia qualquer tipo de situação que pudesse levar a um sistema democrático. Tudo orbitava em torno da pessoa do senhor, desde medidas sociais, como a construção de escolas, até ao julgamento dos direitos, e determinação de penas e castigos (Schwarz, 1992).

Apesar de as ideias propagadas pelos ideais do liberalismo conseguirem, aos poucos, abrir espaço até se tornarem fortes o suficiente para questionarem o poder imperial e propor um modelo republicano, essas ideias, como adverte Schwarz terão, por aqui, um apelo diferente, e até mesmo paradoxal. Foi a origem do que Schwarz chamou de "comédia ideológica", referindo-se à dificuldade de nossa sociedade em aderir aos ideais da burguesia europeia. A solução foi uma aderência superficial dos valores liberais, de modo que as relações econômicas e o poder político permaneceram nas mãos das elites agrárias 
(Schwartz, 1995). José Murilo de Carvalho traz uma contribuição interessante para ilustrarmos essa situação: "um ambiente que Evaristo de Moraes chamou com felicidade de porre ideológico, e que poderíamos chamar, sob a inspiração de Sérgio Porto, de maxixe do republicano doido”. (Carvalho, 1991 p.24). Sérgio Buarque de Holanda também pode contribuir para reforçarmos mais as tintas desse quadro:

\begin{abstract}
"Como esperar transformações profundas em um país onde eram mantidos os fundamentos tradicionais da situação que se pretendia ultrapassar? Enquanto perdurassem intactos e, apesar de tudo, poderosos os padrões econômicos e sociais herdados da era colonial e expressos principalmente na grande lavoura servida pelo braço escravo, as transformações mais ousadas teriam de ser superficiais e artificiosas" (Holanda, 1992. P.78).
\end{abstract}

As ideias liberais vão se acomodando, se sobrepondo, exibindo uma capacidade plástica que passa ao largo de um encaixe perfeito. A burguesia urbana que nasce desse contexto despenderá todo o esforço para combater as ideias da "herança rural", mas essas bases tradicionais conseguem manter seu poder político ao que Carvalho entende como "uma vitória do espírito capitalismo desacompanhado da ética protestante" (Carvalho, 1991p. 26). O autor quer dizer é que o modelo de capitalismo que venceu por aqui foi do tipo predatório que tinha como objetivo o enriquecimento pessoal e a manutenção do poder, muito diferente daquele das Colônias do Norte, que junto com o capitalismo, desenvolveram uma noção de direitos e de associativismo. Por aqui, Roberto Schwartz aponta que, devido às características de uma sociedade que se baseava nas relações de pessoalidade e troca, o que se desenvolveu foi a cultura do favor.

\begin{abstract}
"Assim com mil formas e nomes, o favor atravessou e afetou no conjunto a existência nacional (...) Esteve presente por toda parte, combinando-se às mais variadas atividades, mais e menos afins dele, como administração, política, indústria, comércio, vida urbana, Corte etc. E assim o profissional dependia do favor para o exercício de sua profissão, o pequeno proprietário dependia dele para a segurança de sua propriedade, e o funcionário para seu posto. O favor é a nossa mediação quase universal -" (Schwartz, 1995. P.16 Grifo meu).
\end{abstract}

O surgimento de uma vida urbana, que deveria trazer relações mais impessoais não provocou o desaparecimento da cultura do favor $^{39}$, ao contrário, observou-se uma "acomodação" entre os dois elementos. Nas palavras de Schwartz: "Além dos naturais debates, este antagonismo produziu, portanto, uma coexistência estabilizada", e conclui que: "sem prejuízo de existir, o antagonismo se desfaz em fumaça e os incompatíveis saem de mãos dadas” (p.17). Aqui é interessante chamar atenção para o fato de que, os países

\footnotetext{
39 É importante ressaltar que Schwartz não faz um juízo de valor sobre o favor, sua preocupação é em demonstrar esse elemento como uma característica de nossa sociedade, por isso escreve:

"Em suma, se insistimos no viés que escravismo e favor produziram nas ideias do tempo, não foi para descartar, mas para descrevê-las enquanto enviesadas, fora de centro em relação à exigência que elas mesmas propunham, e reconhecivel nossas, nessa mesma qualidade" (p.19).
} 
ocidentais seguiram uma lógica segundo a qual a produção agrícola impulsionou o desenvolvimento dos centros urbanos, mas no Brasil, conforme aponta Holanda, ocorreu o "reverso de tal medalha", isto porque "nos centros urbanos brasileiros nunca deixaram de se ressentir fortemente da ditadura dos domínios rurais" (p.89). Deste modo, se nos outros países a cidade foi o placo do desenvolvimento das ideias de cidadania (Carvalho, 1991) no Brasil ela foi apenas uma coadjuvante, visto que os processos de construção político e social foram mantidos por muitos anos sob o poder rural ou sob a "herança rural". Podemos, assim, apontar para a ausência de igualdade na participação da vida pública. Muitos comerciantes, os habitantes da cidade, se queixavam do monopólio dos senhores de terras sobre as atividades públicas, mas essas queixas eram em vão, porque a posição destes senhores "podia ser considerada tão alta como os títulos de nobreza dos grandes do reino de Portugal” (Holanda, 1995 p. 89). A cidade era "vazia", ou seja, não era palco de agitações ou de novas formas de relação social. Ao contrário, era basicamente habitada por "alguns funcionários da administração, oficiais, mecânicos e mercadores em geral (...). Sucedia, assim, que os proprietários se descuidavam frequentemente de suas habitações urbanas, dedicando todo o zelo à moradia rural" (Holanda, 1995 p.90).

Com a abolição da escravidão em 1888 e o início da Primeira República em 1889, as cidades, sobretudo o Rio de Janeiro que havia sido capital do Império e se consolida como a capital da República, começam a receber uma grande quantidade de trabalhadores livres, sejam os ex-escravos ou os imigrantes europeus recém chegados sem que houvesse uma infraestrutura adequada com relação ao direitos sociais de habitação, saneamento, saúde e segurança. As cidades começam a se reconfigurar e o que antes era "vazio e inerte", passa a ser "dinâmico e precário" (Carvalho, 1991). Mas as mudanças não ficam apenas na reconfiguração das cidades: a relação entre a sociedade e o Estado também apresenta mudanças a partir desse período, visto que a afluência de pessoas foi acompanhada pela de novas ideias. Nas palavras de José Murilo, o Rio de Janeiro era o centro de "mistura de várias vertentes do pensamento europeu" (Carvalho, 1991p. 24). O liberalismo e o positivismo já estavam por aqui desde o Império, mas a partir da Primeira República os imigrantes italianos e alemães são responsáveis pela chegada das ideias socialistas e pelo anarquismo. Conforme observa Carvalho (2002) continuávamos a importar ideias, sem, contudo, produzi-las. Em suas palavras:

\footnotetext{
"A república não produziu correntes ideológicas próprias ou novas visões estéticas. Mas por um momento houve um abrir de janelas, por onde circulavam mais livremente ideias que antes se continham no recatado mundo imperial" (Carvalho, 1991p. 24).
} 
Essas ideias começam a circular de modo mais perceptível graças à proximidade das relações produzidas pela vida nas cidades e uma nova tensão entre os adeptos do sistema republicano e os "órfãos" do império vai ganhando força. De um modo geral, os adeptos do sistema republicano eram os filhos dos grandes fazendeiros, que haviam sido instruídos em escolas e universidades na Europa, comerciantes e profissionais liberais. Os "órfãos” do império eram, sobretudo, indivíduos pertencentes aos estratos mais pobres que tinham uma relação simbólica e de gratidão com a Coroa (Carvalho, 1991).

Essa tensão entre republicanos e "órfãos" do império vai marcar o processo de construção da relação entre Estado e sociedade no Brasil. A formação do regime republicano não se ocupou em inserir a maioria da população que era composta por pobres e negros descendentes do sistema de escravidão, gerando um distanciamento entre quem, efetivamente participaria das decisões políticas, e aqueles que ficariam fora dessa relação, ou seja, o "povo". Para José Murilo de Carvalho:

\footnotetext{
"Esta extraordinária revelação confirma o abismo existente entre os pobres e a República e abre fecundas pistas de investigação sobre um mundo de valores e ideias radicalmente distintos do mundo das elites e do mundo dos setores intermediários" (p.31)
}

Esse abismo do qual José Murilo fala é evidenciado pela ausência de políticas públicas para a população negra, que era a maioria da população, e foi deixada a própria sorte. A condição de "estar a própria sorte" nesse caso, significou ser o responsável pelo próprio destino "deitando sobre seus ombros a responsabilidade de se reeducar e de se transformar para corresponder aos novos padrões ideais do ser humano (Fernandes, 1964. p. 29).

A partir dessa configuração, as agitações populares passam a ser frequentes e a grande dificuldade desse novo regime será produzir um pacto de poder que gerasse estabilidade. A ampliação do processo eleitoral parecia uma saída para resolver esse "distanciamento" entre Estado e sociedade, mas devido ao "falseamento do processo eleitoral e da representatividade política. O número de eleitores foi mantido sempre em níveis baixíssimos, e o processo eleitoral foi totalmente falseado pela intimidação, pela violência e pela fraude. (Carvalho, 1991p. 35). As fraudes sistêmicas que ocorria no processo eleitoral e a postura autoritária das elites que estavam no poder geraram descrença, frustração e afastamento de boa parte da população nos negócios públicos, como podemos ver na passagem a seguir: 
"Desapontaram-se os intelectuais com as perseguições do governo Floriano; desapontaram-se os operários, sobretudo sua liderança socialista, com as dificuldades de se organizarem em partidos e de participarem do processo eleitoral; os jacobinos foram eliminados" (Carvalho, 1991p. 37).

Esse afastamento teve duas consequências. A primeira foi a formação de uma "representação municipal solta sem ter que prestar contas a um eleitorado autêntico (...) abrindo campo para os arranjos particularistas, para as barganhas pessoais, para o tribofe e para a corrupção" (Carvalho, 1991p. 37). A segunda, e de acordo com Carvalho, a mais perversa, foi o fenômeno da estadania. De acordo com esse autor.

\footnotetext{
"A reação, pragmática antes que ideológica, a esta situação por parte dos que se viam excluídos do sistema foi o que chamamos de estadania, ou seja, a participação, não através da organização dos interesses, mas a partir da máquina governamental, ou em contato direto com ela. Foi o caso específico dos militares e do funcionalismo em geral e de importantes setores da classe operária" (Carvalho, 1991p. 65).
}

Podemos complementar essa análise, apontando que a ausência de um canal legitimo de participação também gerou situações de favorecimento e cooptação, isso porque foi estabelecida uma relação, na qual os direitos eram obtidos, não por meio da participação política e de manifestações, mas por meio de arranjos e da doação direta por parte do Estado.

A Revolução de 1930 foi um marcador importante nessa construção da relação entre Estado e sociedade. Diferentemente da Proclamação da República que não contou com a participação popular, a Revolução de 1930 apresenta um "ensaio" da participação popular como aponta Carvalho " O povo não esteve ausente como em 1889, não assistiu bestializado ao desenrolar dos acontecimentos. Foi ator no drama, posto que coadjuvante" (Carvalho, 2001, p.96). Podemos identificar que o povo não se manteve alheio, mas ainda não conquistou o lugar de protagonista. A posição de "coadjuvante" interessava aos reformistas que tinham interesse realizar certas "modernizações" e não queriam que o povo atrapalhasse com manifestações e "badernas". A prova disso está no fato de que todas as manifestações políticas eram reprimidas de modo violento pela polícia, além disso, havia também forte censura na imprensa. A medida mais radical do governo e que comprava essa aversão a participação popular se deu com a intervenção do governo nos sindicatos.

Esse momento de intervenção do Estado com o objetivo de abafar qualquer tipo de manifestação popular, aliado a novas formas de organização da estrutura administrativa, foi identificado por Wanderley Guilherme dos Santos como o período de cidadania regulada. Para o autor: 
“A regulamentação das profissões, a carteira profissional e o sindicato público definem, assim, os três parâmetros no interior dos quais passa a definir-se a cidadania. Os direitos dos cidadãos são decorrência dos direitos das profissões e as profissões só existem via regulamentação estatal. $O$ instrumento jurídico comprovante do contrato entre Estado e cidadania regulada é a carteira profissional que se torna, em realidade, mais que uma evidência trabalhista, uma certidão de nascimento cívico" (Santos, 1979, p.76).

A estratégia que o Estado desenvolveu para se relacionar com a sociedade foi por meio da cooptação e do controle e, deste modo, evitava qualquer tipo de conflito como aponta Carvalho: "Empregados e patrões eram obrigados a filiar-se a sindicatos colocados sobre o controle do governo" (p.109). Através dos benefícios sociais dados somente aos trabalhadores sindicalizados, o governo cooptava a massa popular que ficava entre "liberdade sem proteção ou proteção sem liberdade" (Carvalho, 2001, p.122).

A "regulação" da cidadania se dava deste modo: os direitos civis e políticos são restringidos, mas em troca, são doados os direitos trabalhistas ${ }^{40}$, ou seja, os direitos sociais. É importante enfatizar que essa "troca" não foi negociada com a sociedade, ao contrário, os direitos foram cedidos, antes mesmo que tivessem se tornado uma reinvindicação.

O aspecto negativo mais dramático dessa relação do Estado com a sociedade por meio de uma cidadania regulada está na exclusão de algumas categorias de trabalhadores do meio urbano como, por exemplo, as empregadas domésticas, ou ainda, os vendedores ambulantes e todos os trabalhadores que não estavam enquadrados na estrutura sindical. Somado a esses trabalhadores, estavam os trabalhadores rurais, que eram a grande maioria na época. Deste modo, ao invalidar o princípio fundamental dos Direitos Humanos que é a universalidade no acesso aos direitos, o Estado brasileiro desqualifica a própria noção de cidadania. Para José Murilo de Carvalho, a consequência dessa situação, está na formação de um "cidadão passivo", que tem como atitude convencional a espera pelas medidas do Estado, ou seja, um cidadão que não reivindica seus direitos, mas que sempre espera a iniciativa do Estado. Deste modo, o resultado é "uma cidadania passiva e receptiva, o oposto de uma cidadania ativa e reivindicatória" (Carvalho, 1987, p.127).

Até este ponto, pudemos observar que a característica autoritária do Estado brasileiro foi crucial para restringir a experiência dos indivíduos na esfera pública, ao que José Murilo

\footnotetext{
40 Refere-se aos direitos implementados principalmente entre 1932 e 1943, tais como a carteira de trabalho, o salário mínimo igual para homens e mulheres, a jornada de trabalho até oito horas, a previdência social (através dos IAPS) e a Consolidação das Leis Trabalhistas, através de uma justiça do trabalho.
} 
de Carvalho chamou de "estadania" e Wanderley Guilherme dos Santos de "cidadania regulada".

O golpe militar de 1964 elimina de vez qualquer tipo de tentativa de uma cidadania ativa que pudesse estar em curso. Os militares passam a comandar o Estado e a forma de diálogo com a sociedade será, mais uma vez, por vias autoritárias. O governo militar passa, inclusive, a utilizar uma estratégia que havia sido utilizada pelo Estado Novo: restringe os direitos políticos e civis de um lado e concede direitos sociais do outro. A novidade agora será o que José Murilo de Carvalho denominou de "paternalismo social e foco na ideologia do desenvolvimento" (Carvalho, 2001, p.190). Esse paternalismo social foi usado para compensar a ausência de liberdade, tendo, inclusive, inserido os trabalhadores rurais no âmbito dos direitos sociais com a criação do fundo do trabalhador rural. Já a ideologia do desenvolvimento, foi a responsável por deixar a classe média satisfeita, a ponto de "fechar os olhos" para a perda de seus direitos políticos e civis.

Essa relação entre o Estado militar e a sociedade parecia ter encontrado um ponto de acomodação, até que o "milagre econômico" foi se mostrando uma falácia e a classe média, começou a dar sinais de descontentamento. Além disso, toda a parcela da população que tinha ficado de fora da "divisão do bolo", ou seja, os operários, as classes pobres, estavam sufocados pelo arrocho salarial e já experimentavam o agravamento das desigualdades sociais. A soma desses fatores, provocou na população uma saída para manifestações na esfera pública e uma participação efetiva. Prova disso está no movimento pelas "Diretas Já". José Murilo de Carvalho traz uma colaboração sobre essa nova configuração da sociedade "os brasileiros iniciaram o que se chamou de Nova República com o sentimento de terem participado de uma grande transformação nacional, de terem colaborado na criação de um país novo" (p. 193).

As Diretas Já, a queda do regime militar, a Assembleia Constituinte e a Constituição de 1988, que recebe a designação de Constituição Cidadã, consolidam essa reconfiguração da relação entre o Estado e a sociedade, tendo essa última encontrado o caminho da mobilização na esfera pública.

A Constituição de 88 tem potencial para produzir uma reparação histórica de todo o passado autoritário, excludente e de esfera pública restritiva. Para Vera Telles, por meio dessa Constituição, buscou-se a superação de nossas "incompletudes", visto que foram ampliados os canais para participação, além do fortalecimento da sociedade civil:

"Os anos 80 revisitando sua história, instituições e tradições por referência o que parecia como mais um momento na sempre difícil e ambivalente 'formação 
do país, na sempre adiada superação das várias incompletudes de sua história" (Telles, 2001p.9)

Contudo, Elisa Reis (1995), através de uma visão mais crítica, alerta para os "perigos da sociedade civil". De acordo com a autora, a sociedade civil não pode ser a responsável exclusiva pela manutenção do canal de diálogo entre o Estado e os indivíduos, visto que ela pode assumir feições diferentes. Por exemplo, no caso de grupos que não conseguem ter seus anseios atendidos e partem para ações extremas como o isolamento em comunidades fechadas como no caso do comunitarismo cristão, ou em outros casos como os grupos que buscam interesses corporativistas ou clientelistas. Essa "feição diferente" da sociedade civil destrói uma das características básicas da "virtude cívica" que é a "solidariedade social".

Se Elisa Reis nos deixa com uma visão crítica, Evelina Dagnino (1994) nos trazia na época uma visão positiva da sociedade civil. Por meio de exemplos práticos, como o caso do orçamento participativo no Rio Grande do Sul, demonstra como a sociedade civil organizada pode animar a esfera pública e produzir um modelo de cidadania ativa.

Seja com ambivalências, apresente limites ou até mesmo fraquezas, a questão é que a sociedade civil possui a capacidade de organizar as demandas do interesse coletivo e produzir relações baseadas na ampliação de direitos e na participação na esfera pública. Essas características são de extrema importância para a sociedade brasileira, sobretudo para que consigamos superar os antigos entraves e alcancemos uma inserção na modernidade, capaz de resolver nossos problemas sociais, políticos e econômicos, superando de modo definitivo as desigualdades sociais.

Sabemos que, mesmo com toda a participação da sociedade civil que culminou na Constituição Cidadã, diversos entraves impossibilitaram a efetivação da conquista desses direitos. Para Vera Telles:

\footnotetext{
"Na conjugação entre os legados da história e os processos em curso explicitam-se as difíceis e dilemáticas relações sociais entre o mundo social e o universo público dos direitos .E se essa questão importa, é porque é nesse lapso entre o mundo social e o universo público (...) que se inscrevem os dilemas de uma cidadania ainda a ser conquistada e reinventada nos termos que o mundo contemporâneo está exigir" (Telles,2001p.11)
}

A manutenção dos elementos responsáveis pelas desigualdades sociais fez com que nossa sociedade fosse dividida em extremos com realidades completamente opostas. Numa extremidade está uma parcela da população, os excluídos, para esses o acesso aos direitos é dificultado por uma série de questões, que vão desde uma concepção de "mundo católica préconciliar" "em que cada coisa estava em seu devido lugar, mesmo que 
desigual" (Paiva,2003) até o desconhecimento dos direitos e, na outra extremidade, está a parcela da população para a qual o acesso aos direitos se dá de maneira fluída.

Essa dificuldade no acesso aos direitos por uma parcela da população não só gerou uma sociedade desigual, como também criou uma "esfera relacional" como aponta Roberto DaMatta. Segundo esse antropólogo, a “esfera relacional” é a face de uma sociedade que, por ser relacionar com base na hierarquia, e com "aversão à igualdade", faz com que "uns sejam mais cidadãos que outros", por meio de "mecanismos distintivos", como por exemplo, o “jeitinho” (DaMatta, 1984, pp.96-97). Dentro dessa lógica social descrita por DaMatta, o "jeitinho" teria como finalidade fazer a distinção entre o indivíduo e a pessoa. O "indivíduo" seria o "sujeito das leis universais que modernizam a sociedade" e a "pessoa" seria o sujeito das relações sociais, que conduz ao polo tradicional do sistema", ambos teriam um espaço próprio de atuação, que seria "a casa" e "a rua" respectivamente. $\mathrm{Na}$ "rua" as regras valem para todos e não existe a familiaridade, já a "casa", é caracterizada pelas relações com base na familiaridade. Deste modo, o "jeitinho" seria uma hibridez, uma articulação entre o universo da "casa" e da "rua" própria dos momentos em que as leis oferecessem obstáculos às expectativas de cada um. (DaMatta, 1984, p.107).

O "jeitinho" faz com que a esfera pública brasileira tenha uma configuração própria, com certa resistência à igualdade e uma visão particularista dos direitos. De uma perspectiva da desigualdade social, é o que Angela Paiva chama de "esquizofrenia social" e que produzirá como resultado uma "cidadania disjuntiva", visto que há um projeto de integração social incompleto na construção da cidadania no Brasil. Segundo essa autora: "há uma tendência ao cultivo de valores distintos diante de situações idênticas", (...) nessa visão esquizofrênica, o 'outro' aparece geralmente como um grupo social nebuloso, cujos problemas precisam ser solucionados para que o 'nosso' possa seguir na realização esquizofrênica da cidadania disjuntiva" (Paiva, 2004 p.12). Decorre dessa dinâmica, o fato de que a maior parcela da sociedade ainda se encontra sem possibilidade de usufruir dos bens sociais, como o acesso à justiça, à educação, condições estas imprescindíveis e fundamentais à universalização do conceito de cidadania. Segundo Telles (1994):

Em uma sociedade como essa, a afirmação das diferenças quando não repõe privilégios, é feita na lógica de discriminação que transfiguram desigualdades em modos de ser não apenas distintos, mas incomensuráveis (...) E isso se projeta por inteiro o drama da pobreza brasileira. Pois as distâncias sociais são tão grandes que parece não ser plausível uma medida comum que permita que a questão da justiça se coloque como problema e critério de julgamento nas relações sociais; o fosso social é imenso e, parece mesmo obstruir a possibilidade mesma de uma linguagem comum e, portanto, do convívio social, interlocução e debate comum em torno de questões pertinentes. Isto é propriamente o apartheid social. (id. p.95). 
A consequência dessa "cidadania disjuntiva" estaria na nossa dificuldade em estabelecer uma relação equânime entre os indivíduos e os direitos, aquilo que Telles (2001) chamou de "gramática civil" comum a todos, visto que, devido à desigualdade, grupos não compartilham normas e valores e os direitos são conferidos de forma desigual, tende a necessitar tipos diferentes de direitos. Por isso é preciso que, ao analisarmos a questão da cidadania, olhemos "pelo ângulo da dinâmica societária", visto que "os direitos dizem respeito, antes de mais nada, ao modo como as relações sociais se estruturam" (Dagnino, Evelina,1994, p.91)

Deste modo, podemos observar que a nossa formação histórica-social produziu um modelo próprio de relação entre Estado e a Sociedade e que nosso maior desafio desde a redemocratização consiste em assegurar efetivamente uma igualdade mínima entre os indivíduos para que possam ter condições de experimentar aquilo que Hannah Arendt em sua obra "A condição humana" chamou de " segundo nascimento", ou seja, o ingresso do indivíduo na esfera pública com vista à ação, assegurando desse modo, o "direito a ter direitos", ou seja a cidadania (Arendt, 1993).

Cabe aqui, ressaltar que o conceito de cidadania é dinâmico, no sentido de que está sempre em expansão, e quem articula essa movimentação são os indivíduos que buscam, de diferentes maneiras, (por meio de associações, via movimentos sociais, provocando a esfera jurídica, pressionando o Estado, dentre outras formas) incluir novos direitos ao lutarem por uma esfera pública mais plural e uma cidadania menos restritiva. Os jovens, inclusive, historicamente se mostraram agentes catalisadores de novos direitos. Parte importante da pesquisa de campo do nosso trabalho foi trazer a questão da cidadania para ver o que pensam os jovens analisados sobre esse conceito: cidadania.

\section{2}

As desigualdades influenciam na percepção dos jovens sobre a cidadania? Alguns resultados da pesquisa

Perguntamos para os jovens o que é ser cidadão e as respostas podem ser observadas nas tabelas abaixo: 
Tabela 4.0 - Dados da pesquisa atual

\begin{tabular}{|lr|lr|}
\hline \multicolumn{1}{|c|}{$\begin{array}{c}\text { Ser cidadão } \\
\text { Rede particular }\end{array}$} & \multicolumn{2}{c|}{$\begin{array}{l}\text { Ser cidadão } \\
\text { Rede pública }\end{array}$} \\
\hline Participar da vida política e social do país & $56,0 \%$ & Participar da vida política e social do país & $33,7 \%$ \\
\hline Uma dificuldade & $12,5 \%$ & Uma dificuldade & $28,1 \%$ \\
\hline Ser consumidor & $12,5 \%$ & Ser consumidor & $22,5 \%$ \\
\hline Ser honesto & $10,6 \%$ & Ser honesto & $10,1 \%$ \\
\hline Uma ilusão & $3,1 \%$ & Uma ilusão & $3,4 \%$ \\
\hline Exercer um cargo político na sociedade & $1,3 \%$ & Exercer um cargo político na sociedade & $2,2 \%$ \\
\hline
\end{tabular}

Na pesquisa atual, os jovens de ambas as redes entendem "ser cidadão" como a ação de participar da vida associativa do país. É interessante observar que na pesquisa anterior, as respostas foram completamente diferentes. Há quinze anos, os jovens da rede pública e particular divergiram em todas as opções de resposta.

Tabela 4.1 - Dados da pesquisa anterior.

\begin{tabular}{|lr|llr|}
\hline \multicolumn{1}{|c|}{$\begin{array}{c}\text { Ser cidadão } \\
\text { Rede particular }\end{array}$} & & \multicolumn{2}{c|}{ Ser cidadão } \\
Rede pública
\end{tabular}

A maioria dos jovens da rede pública dizia que ser cidadão era "ser consumidor e ter o direito de usufruir dos bens que a sociedade oferece" e os jovens da rede particular apresentavam como resposta principal a opção "participar da vida política e social do país". Contudo, na pesquisa atual identificamos que a opção "ser consumidor" apresentou uma redução, ficando em terceiro lugar, enquanto a opção "participar da vida política e social do país" foi a mais indicada pelos jovens. Para os jovens da rede pública a definição de cidadão como uma ilusão aparece em segundo lugar, com quase $20 \%$ das respostas, enquanto para os jovens da rede particular, essa opção não chega a 10\% das respostas. As opções "ser honesto" e "uma dificuldade" ficam nas últimas posições para os jovens das duas redes de ensino.

A pesquisa atual aponta uma nova configuração sobre a percepção do que é ser cidadão. Inicialmente, a informação que chama atenção é a porcentagem de jovens da rede particular que escolheram a opção "Participar da vida política e social do país", 56\%, ou seja, mais de 
metade dos jovens entrevistados. Ainda com relação aos jovens da rede particular, temos que as opções "uma dificuldade" e "ser consumidor" aparecem como a segunda opção mais indicada, seguida pelas opções "ser honesto", "uma ilusão" e "exercer um cargo político na sociedade". É interessante observar a redução de jovens que optaram por "exercer um cargo político na sociedade" e "uma ilusão".

A presença da opção "ser consumidor" entre uma das principais respostas apontadas pelos dois grupos de jovens, tanto na pesquisa anterior quanto na atual, nos convoca a pensarmos sobre algumas hipóteses. Aqui, vamos organizar duas delas: a) Consumo como "signo" criado pelo "renascimento liberal" e b) Consumo como experiência de direito.

A primeira hipótese, consumo como "signo" criado pelo "renascimento liberal", tem como base um argumento construído por José Murilo de Carvalho em seu texto "Cidadania no Brasil: o longo caminho. Nesse texto, ao identificar o desenvolvimento de uma cultura do consumo, inclusive entre a população mais excluída, o autor chama atenção para o que ele denomina de "sintomas perturbadores oriundos das mudanças trazidas pelo renascimento liberal"41. Essa situação ocorre devido a uma confusão gerada pelos "novos liberais" (p.228), que usam o consumo para promover uma falsa ideia de "inclusão social". Desse modo, uma percepção desfigurada sobre o liberalismo estaria gerando uma confusão entre a noção de consumo e a de cidadania. Outros dois autores que vão ao encontro dessa interpretação são Alba Zaluar (1997) e Jurandir Freire da Costa (2004). Eles nos ajudarão a trazer essa discussão para o âmbito da juventude. Para Zaluar (1997) o consumo e, sobretudo, o consumo conspícuo tem uma função simbólica entre os jovens, visto que por meio dos objetos consumidos é possível construir uma linguagem de inclusão a certos espaços, por exemplo, quando um jovem veste um produto de marca (que é um objeto de consumo conspícuo) é como se ele estivesse automaticamente habilitado a circular em determinados espaços, os quais sem a presença desse objeto de consumo não seria possível. Deste modo, quando um jovem entra em um shopping vestido com roupas de marcas, ele se sentiria como um "nativo", ou seja, alguém que possui uma relação com aquele lugar, alguém que pode circular sem constrangimentos porque é um consumidor. Costa (2004) aprofunda essa perspectiva sobre a relação entre os jovens e o consumo apontando para uma consequência negativa dessa relação. O consumo geraria uma falsa experiência de participação e integração social, visto

\footnotetext{
41 Carvalho (2002) faz uma análise sobre um ocorrido no início dos anos 2000, que foi a "invasão" de sem-teto em um shopping center no Rio de Janeiro. De acordo com o autor essa situação teria como motivação a reinvindicação das classes mais baixas do direito ao consumo, ou da "cidadania pregada pelos novos liberais". (p.228)
} 
que não se preocupa com o "Bem comum", ao contrário, acaba gerando competição e individualidade e isso é extremamente prejudicial para o avanço democrático.

A segunda hipótese é a do "Consumo como experiência de direito". Desde a criação do Código de defesa do consumidor, em $1990^{42}$ é muito clara a penetração dessas leis nas relações cotidianas de consumo. Prova disso, está na quantidade de ações demandadas ao Juizado Especial de Defesa do Consumidor. De acordo com o Conselho Nacional de Justiça $^{43}$, as ações que têm como tema "direito do consumidor" representam as maiores demandas ao Judiciário desde o início dos anos 2000 e, em 2019, representaram a segunda maior causa de demanda, ficando abaixo apenas das causas de direito Civil. Além disso, situações que invocam o Direito do Consumidor também aparecem de modo sistemático em programas de TV, colunas de jornais e atualmente observa-se a presença de sites específicos para esse tema, os quais se propõem a realizam uma interlocução rápida entre o consumidor insatisfeito e o vendedor. Essas ações certamente ajudam a construir uma percepção coletiva de que as relações de consumo estão diretamente ligadas a defesa de direitos e isso pode ser uma pista para entendermos essa relação tão marcante que os jovens demonstram ao associar ser consumidor com ser cidadão.

Com relação aos demais direitos, observamos que na pesquisa atual ocorreu um certo padrão com relação ao aumento e à redução da adesão dos jovens a algumas respostas. A identificação desse padrão foi obtida por meio da soma das respostas dos jovens das duas redes e a comparação entre os resultados da pesquisa anterior e da atual. Em seguida, organizamos as respostas em dois blocos: a) opções de respostas que apresentaram redução e b) opções de respostas que apresentaram aumento.

a) Redução: ser consumidor, exercer um cargo político na sociedade e uma ilusão.

b) Aumento: ser honesto, participar da vida associativa e uma dificuldade.

\footnotetext{
42 Lei Federal no 8.078 , de 1990

43 Site: https://www.cnj.jus.br/wp-content/uploads/conteudo/arquivo/2019/08/justica em numeros20190919.pdf
} 
Gráfico 3.0 - Dados da pesquisa atual

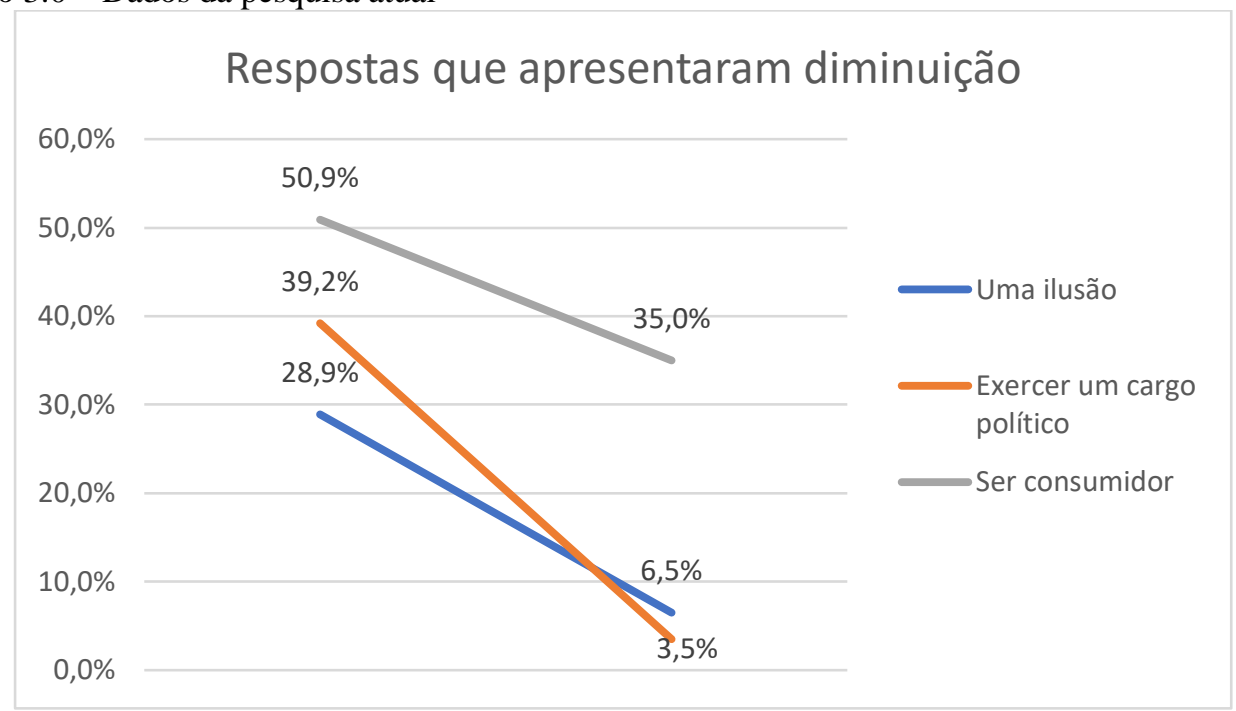

Gráfico 3.1 - Dados da pesquisa atual

\section{Respostas que apresentaram aumento}

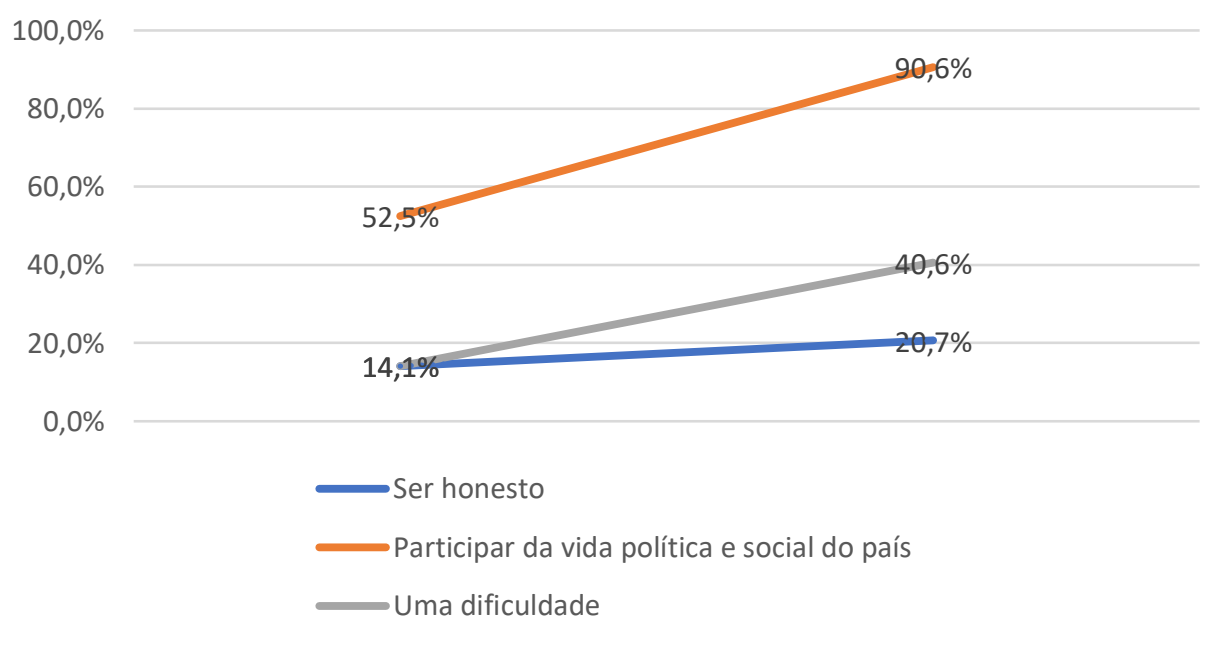

A resposta que apresentou o maior aumento percentual foi "participar da vida política e social do país". Apesar de ter sido a principal resposta dos alunos da rede particular, desde a primeira pesquisa, agora, esse percentual apresenta um aumento significativo nas duas redes, sendo apontada como a principal resposta entre $90,6 \%$ dos jovens entrevistados. A resposta que apresentou a maior queda foi "exercer um cargo político". Esse dado é interessante, visto que, na primeira pesquisa ela aparece como a segunda maior respostada dada pelos alunos da rede privada e agora, na pesquisa atual, apresenta essa queda acentuada. Entre as respostas que tiveram aumento, também chamam atenção as opções "ser honesto" e "uma dificuldade", pois na primeira pesquisa essas foram as últimas opções de resposta entre os alunos da rede pública e agora tiveram um aumento de $6,6 \%$ e $26,5 \%$ respectivamente. 
Depois de analisarmos a percepção dos jovens, sobre o que é ser cidadão por meio de uma pergunta fechada, ou seja, com opções diretas, elaboramos duas perguntas abertas para que os jovens dessem três exemplos de direitos e deveres. Os direitos mais citados, divididos por rede de ensino estão nas duas tabelas a seguir.

Tabela 5.0 - Dados da pesquisa atual

\begin{tabular}{|l|r|}
\hline \multicolumn{2}{|c|}{$\begin{array}{c}\text { Escola pública } \\
\text { Um direito }\end{array}$} \\
\hline Não soube & 47,2 \\
\hline Voto & 10,1 \\
\hline Respeito & 10,1 \\
\hline Ir e vir & 10,1 \\
\hline Liberdade de expressão & 9,0 \\
\hline Saúde & 7,9 \\
\hline Segurança, lazer e educação & 1,1 \\
\hline
\end{tabular}

\begin{tabular}{|l|r|}
\hline \multicolumn{2}{|c|}{ Escola particular } \\
\hline \multicolumn{2}{|c|}{ Um direito } \\
\hline Não soube & 8,8 \\
\hline Liberdade de expressão & 23,9 \\
\hline Saúde & 14,4 \\
\hline Voto & 13,1 \\
\hline Ir e vir & 9,4 \\
\hline Habitação & 7,5 \\
\hline Respeito & 3,8 \\
\hline Vida & 3,8 \\
\hline Igualdade de gênero & 2,5 \\
\hline Segurança, educação, saneamento & 1,9 \\
\hline Dts. trabalhistas e segurança & 1,9 \\
\hline Trabalho & 1,3 \\
\hline
\end{tabular}

Inicialmente o dado que chama atenção é a porcentagem de alunos da rede pública que não souberam dar exemplos de direitos. Essa situação também foi observada na primeira pesquisa, naquela ocasião cerca de $15 \%$ dos jovens dessa rede também não souberam responder. Por outro lado, na rede particular, podemos observar um repertório de direitos bem mais extenso. Os direitos mais citados pelos jovens da rede particular foram: liberdade de expressão, saúde e voto, para os jovens da rede pública foram: voto, respeito e ir e vir.

Ao compararmos com pesquisa anterior, identificamos que houve uma mudança na percepção dos jovens com relação aos direitos. Naquela pesquisa, os três direitos mais citados pelos jovens da rede pública foram: educação, saúde e liberdade de expressão, para os jovens da rede particular foram: liberdade de expressão, educação e direito de ir e vir, nessa ordem. Sendo assim, tínhamos uma prevalência dos direitos civis entre os jovens da rede particular e dos direitos sociais entre os jovens da rede pública. Na pesquisa atual há uma mudança nesse quadro, os direitos civis se sobressaem dentre os demais direitos, tanto entre os jovens da rede pública quanto na rede privada. Para ilustrar essa questão produzimos dois gráficos de adesão ${ }^{44}$, conforme podemos observar a seguir.

\footnotetext{
44 Para construirmos esses gráficos, separamos todos os exemplos de direitos citados pelos jovens e dividimos de acordo com as três categorias formuladas por Marshall (1950), ou seja, direitos civis, políticos e sociais. Em seguida, observamos que a diferença entre os exemplos dados pelos jovens da rede pública e da rede privada eram muito
} 
Gráfico 4.0
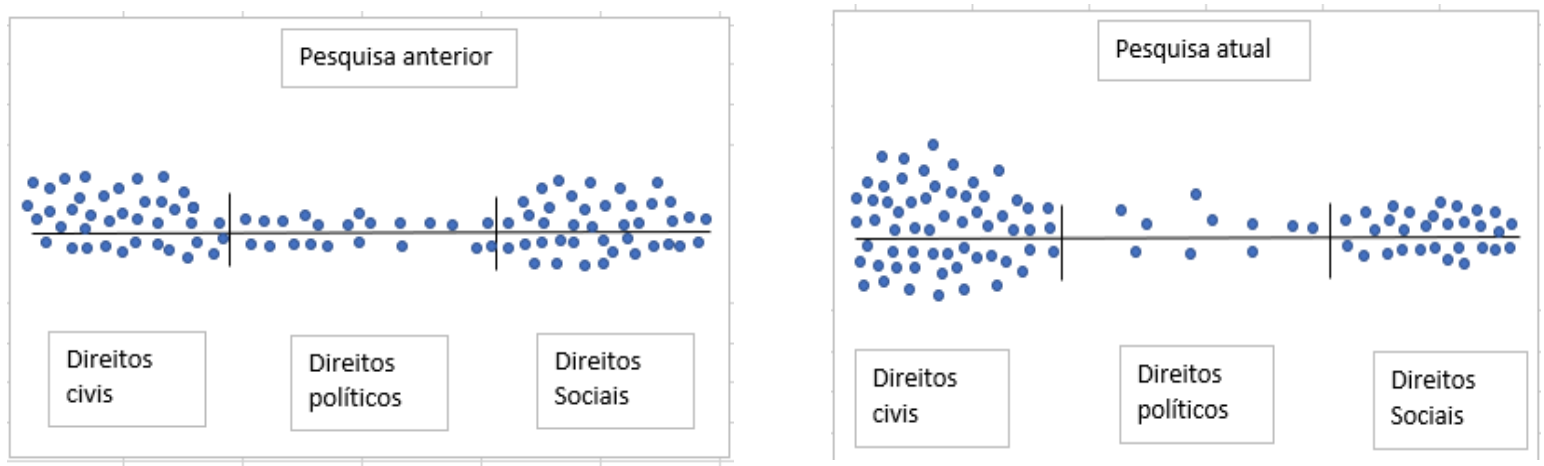

Os gráficos de adesão nos ajudam a visualizar quais foram os tipos de direitos mais citados pelos jovens, na pesquisa anterior e na atual. Podemos observar que na primeira pesquisa os exemplos se dividiam entre direitos sociais e direitos civis, contudo, agora, os jovens apresentam mais exemplos de direitos civis. Com relação aos direitos políticos, o direito ao voto permaneceu como o mais citado pelos jovens das duas redes. Sobre esse direito, o questionário arguia mais três questões: i) Você vota?, ii) Você pretende tirar o título de eleitor com 16 anos e iii)Você considera o voto: a) um direito político importante, b) é bom que seja obrigatório, c) deveria ser opcional e d) não adianta votar.

Com relação a primeira pergunta (você vota?), identificamos uma porcentagem muito próxima entre os jovens das duas redes, por isso, somamos os dados e elaboramos o seguinte gráfico.

Gráfico 5.0 - Dados da pesquisa atual

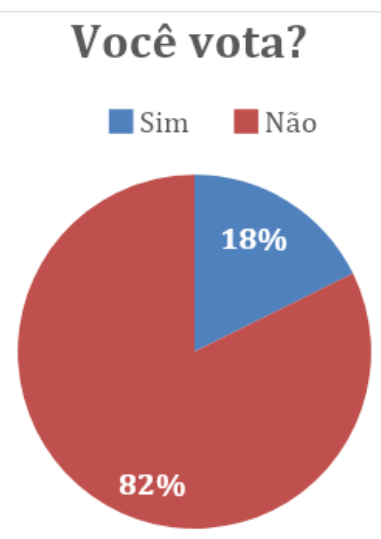

A pergunta "você pretende tirar o título de eleitor com 16 anos?" apresentou porcentagens próximas entre os jovens da rede pública e particular e por isso, somamos os resultados das duas redes, conforme pode ser observado no gráfico a seguir.

pequenas (cerca de 4\%), deste modo, somamos as porcentagens e chegamos aos resultados que podem ser observados nos gráficos. 
Gráfico 5.1 - Dados da pesquisa atual

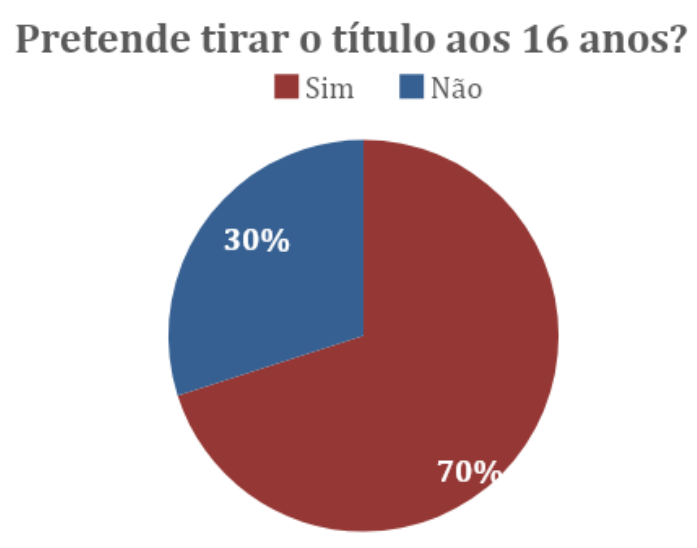

$\mathrm{O}$ alto percentual de jovens que pretendem tirar o título de eleitor aos 16 anos, indica adesão ao processo eleitoral. Aqui, por meio do conceito "cidadão crítico" (dessatisfied democrats) de Pippa Norris (2005), podemos identificar que esses jovens estão dispostos a participar do regime político democrático. De acordo com essa cientista política, as sociedades modernas estariam sob a experiência de um "déficit democrático" que significa o distanciamento entre as demandas dos cidadãos (inputs) e a performance das instituições em responder a essas demandas. Essa situação de "déficit democrático" acabou produzindo um impacto positivo que é uma espécie de "provocação" à participação de novos sujeitos políticos no processo decisório, esses sujeitos são os "cidadãos críticos". Ao invés de se afastarem da arena política, devido ao "déficit democrático", esses cidadãos críticos, por mais que manifestem descrenças com relação às instituições, não desistem de participar. Deste modo, podemos identificar nos jovens de nossa pesquisa, esse cidadão crítico, o qual acredita que ser cidadão "é uma dificuldade", mas apesar disso, manifesta seu interesse em participar ao se propor a tirar o título de eleitor numa idade em que ainda não é obrigatório. O gráfico a seguir colabora com essa aproximação dos jovens com o conceito de "cidadão crítico", nele podemos observar que, para a maioria dos jovens, o direito ao voto é considerado como "um direito político importante". 
Gráfico 5.2 - Dados da pesquisa atual

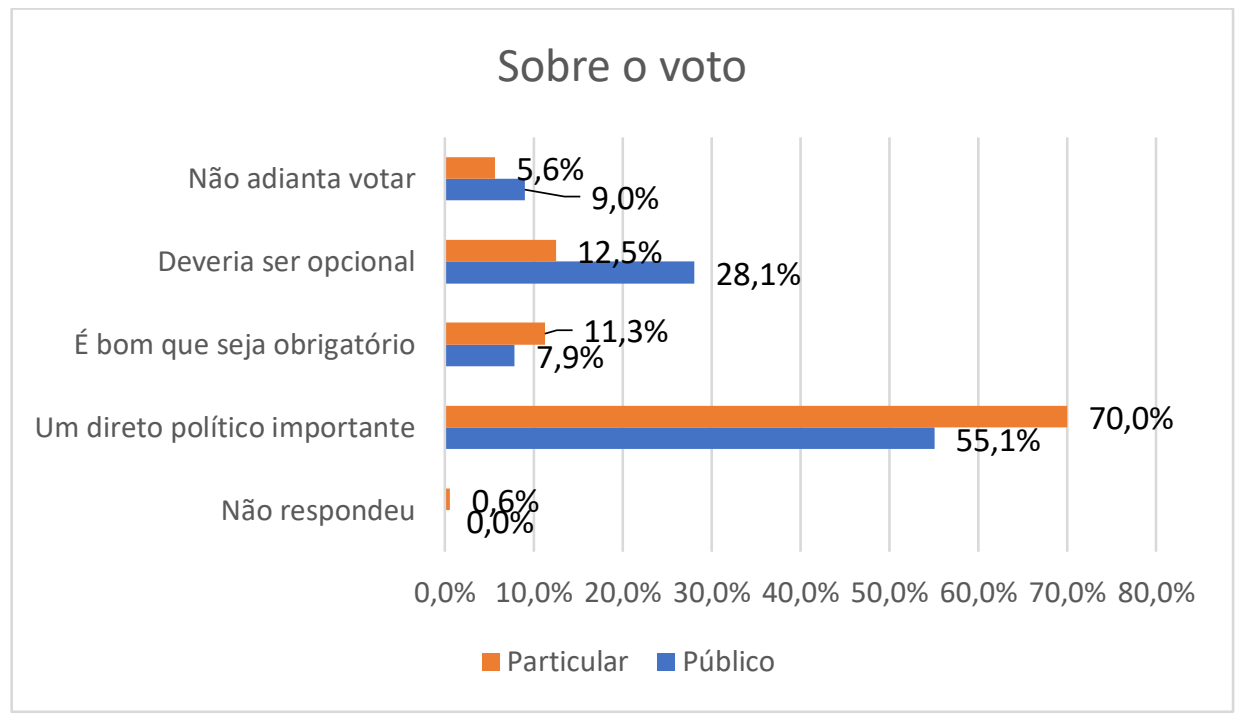

O voto, também aparece em destaque quando o assunto são deveres.

Do mesmo modo como fizemos com os direitos, elaboramos uma pergunta aberta sobre os deveres, nela, os alunos deveriam citar três. Os deveres mais citados estão nas tabelas a seguir.

Tabela 6.0 - Dados da pesquisa atual

\begin{tabular}{|l|r|}
\hline \multicolumn{2}{|c|}{ Rede pública } \\
\hline \multicolumn{2}{|c|}{ Deveres } \\
\hline Não soube & $46,1 \%$ \\
\hline Respeitar às leis & $12,4 \%$ \\
\hline Votar & $10,1 \%$ \\
\hline Respeito (em geral) & $8,8 \%$ \\
\hline
\end{tabular}

\begin{tabular}{|l|r|}
\hline \multicolumn{2}{|c|}{ Rede privada } \\
\hline \multicolumn{2}{|c|}{ Deveres } \\
\hline Não soube & $20 \%$ \\
\hline Votar & $21,9 \%$ \\
\hline Respeitar às leis & $10,6 \%$ \\
\hline Respeito (em geral) & $13,3 \%$ \\
\hline Pagar impostos & $10,0 \%$ \\
\hline
\end{tabular}

O desconhecimento dos deveres é alto nas duas redes, com destaque para os quase $50 \%$ de alunos da rede pública que não souberam citar qualquer tipo de deveres. Além do voto, o "respeito às leis" também aparece nas duas redes, o dever de "pagar impostos" foi citado por $10 \%$ dos jovens apenas na rede particular. Além disso, chama atenção o "respeito em geral", somando as duas redes, foram cerca de $20 \%$ dos jovens que citaram esse exemplo como um dever. Visto que as porcentagens dos exemplos de deveres se aproximam nas duas redes, vamos somá-los para construirmos uma visão geral sobre esse tema a partir do gráfico a seguir. 
Gráfico 6.0

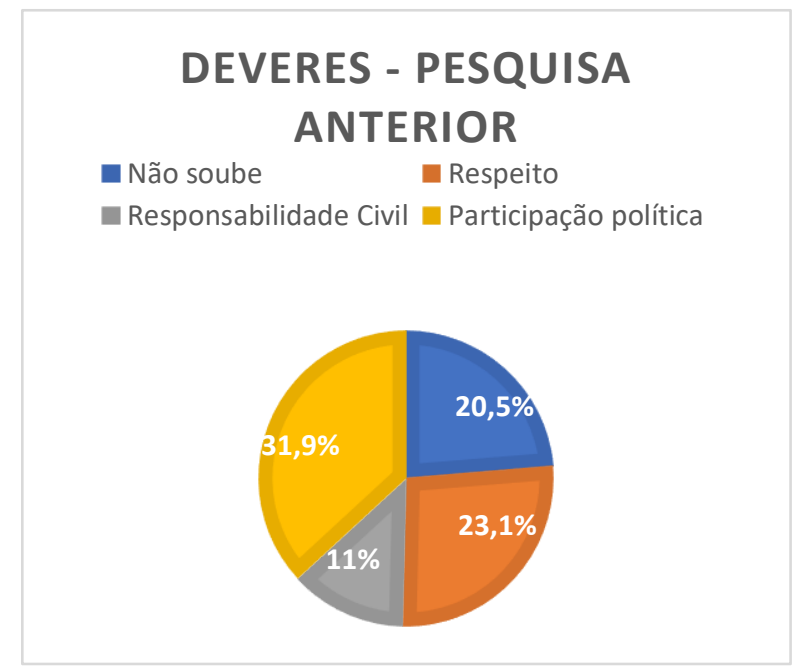

Gráfico 6.1

\section{DEVERES - PESQUISA ATUAL}

não soube $\quad$ Votar

Respeitar às leis $\quad$ Respeito (em geral)

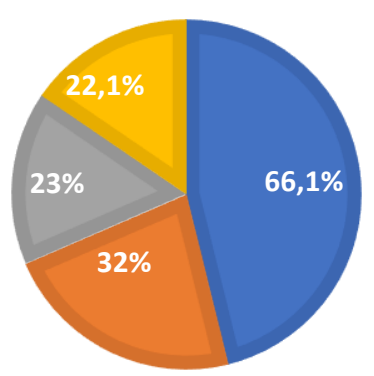

Identificamos na pesquisa anterior, o "voto" não foi citado como um dever, mas a "participação política" foi indicada por 31,9\% dos jovens, além da ideia de "responsabilidade civil" que foi apontada como resposta para $11 \%$ dos jovens. Chama atenção o fato de os jovens citarem, de modo expressivo, o "respeito" (de um modo geral) como um dever, tanto na pesquisa atual quanto na anterior. A análise dessa relação dos jovens com os deveres e direitos será aprofundada ao investigarmos sobre a confiança que eles demonstram pelas instituições, tais como judiciário, militares, política, dentre outros. Além disso, identificaremos de que forma participam e o quanto se sentem à vontade. 


\section{Cultura cívica: do que se trata?}

Seguindo a mesma organização dos itens anteriores (juventude e cidadania), vamos apresentar o conceito de cultura cívica, inicialmente por meio do diálogo entre autores que são referências no tema, como Tocqueville e Robert Putnam e, depois traremos a discussão para o contexto brasileiro e finalmente, apresentando os dados da pesquisa que nos ajudam a problematizar o conceito na perspectiva dos jovens.

Tocqueville é um dos primeiros autores a perceber os elementos que irão constituir a ideia de cultura cívica. Ao analisar a sociedade norte-americana, identifica uma relação "de igualdade" entre os indivíduos que caracterizou como um movimento "irresistível". De acordo com Marcelo Jasmin (1997) ${ }^{45}$, Tocqueville tinha essa noção de "marcha irresistível da democracia" por experenciar um processo de transição entre dois tempos: o fim do Antigo Regime (que foi o tempo de seus pais) e o surgimento da sociedade burguesa ( $\mathrm{p} 21$ ).

Fazendo uma comparação com a sociedade aristocrática francesa, Tocqueville observa que nos Estados Unidos, fatores como a igualdade de condições, a valorização dos negócios econômicos e a liberdade política, encontram-se diretamente relacionados, ao contrário do que era observado na França aristocrática. A burguesia emergente na França, bem como os norte-americanos, rompe com os padrões de hereditariedade e repelem o estado de subordinação, passando a exigir limites ao poder do governante e uma participação ativa nas decisões públicas. Esse quadro configura a saída do súdito, o qual só tinha obrigações e obediência e a emergência do indivíduo com direitos, ou seja, o cidadão. Contudo, o autor observa que esse movimento de "igualização" levaria à perda da liberdade, isso ocorreria porque a igualdade, levaria os indivíduos ao isolamento e à alienação cívica do bem-estar da vida privada, deixando, desta forma, a esfera pública vazia e livre para o desenvolvimento de um "Estado nacional centralizado", implicando automaticamente na perda da liberdade. O antídoto para essa solução também é identificado por Tocqueville e está no que ele identifica como "instituições livres", ou seja, as associações civis. Essas teriam como função o combate ao individualismo, visto que incentivariam o preenchimento do espaço público. De acordo com ele, "nos Estados Unidos, as pessoas se associam com fins de segurança pública, de comércio, de indústria, de moral e de religião." (p.406)

\footnotetext{
45 Marcelo Jasmin é um dos maiores especialistas em Alexis de Tocqueville e seu livro "Alexis de Tocqueville: a historiografia como ciência da política, servirá de apoio neste momento de nossa dissertação.
} 
As associações fazem com que, ao invés do individualismo causado pela igualização, os indivíduos tenham mais gosto pela participação na esfera pública, contudo essa motivação não parte de um sentimento altruísta, mas um cálculo interessado de cada indivíduo, algo que Tocqueville chama de "interesse bem compreendido".

Deste modo, as associações civis são as grandes responsáveis pela manutenção da liberdade, ao impedir a privatização das relações sociais e a progressiva indiferença cívica. Mas ainda assim, essas associações civis têm um desafio para assegurar a liberdade, segundo Tocqueville o governo representativo pode vir a ser um "veneno" para a liberdade. Ao atribuir a um outro indivíduo a função de atuação nos negócios públicos, mais uma vez, os indivíduos poderiam se sentir atraídos pela vida na esfera privada, deixando a esfera pública a cargo dos representantes. Além disso, por meio do sistema representativo, poderia haver um "império moral da maioria". Nessa situação, a maioria sempre conseguiria fazer sua vontade, deixando a minoria refém da obediência e da censura. Essas duas situações têm como solução o próprio associativismo. Os indivíduos podem, por meio da associação, tanto eleger, quanto unir esforços para cobrar dos políticos uma atuação que os representem, do mesmo modo, o "império moral da maioria" pode ser contido pela união das "minorias" em outras associações civis e assim, Tocqueville chega à conclusão de que: "O problema está menos na forma de governo que no espírito do homem democrático" (Jasmin,1997 p. 73). É desta frase que identificamos o valor do associativismo percebido por nosso "observadornarrador". Se o homem democrático mantiver seu "interesse bem compreendido" e com ele sua participação nas “instituições livres”, a democracia seguirá sua "marcha irresistível”.

Podemos concluir que a cultura cívica é a base 'para' e 'da' democracia. 'Para' a democracia porque é a partir dos valores que habilitam a participação na esfera pública que os indivíduos constroem os sistemas democráticos e é base 'da' democracia porque é a própria participação que mantém esse sistema.

Assim como Tocqueville, o outro autor que se debruçou sobre o conceito de cultura cívica também se propôs a realizar um estudo comparativo. No entanto, podemos dizer que ele é um "Tocqueville ao contrário", visto que sai dos Estados Unidos e vai buscar explicações sobre o desempenho da democracia no Velho Mundo, mais especificamente, na Itália. Robert Putnam observa a Itália a partir dos anos 1970, quando se iniciou o processo de descentralização administrativa ${ }^{46}$. Nesse contexto, o pesquisador vai percorrer vinte regiões, do Norte ao Sul da Itália para identificar a qualidade da democracia, para tanto,

\footnotetext{
46 O principal intuito desse processo de descentralização era reduzir as desigualdades regionais e estimular o desenvolvimento social e econômico.
} 
elabora perguntas norteadoras que tem como objetivo buscar compreender porque a diferença na qualidade da democracia e do desempenho econômico em algumas regiões da Itália.

Antes do processo de descentralização, as tomadas de decisões políticas e administrativas da Itália eram centralizadas em Roma e essa situação acabou gerando consequências negativas, como por exemplo, um sistema clientelista, corrupto e de privilégios. Por esse motivo, quando o processo de descentralização político-administrativa foi iniciado, encontrou grande resistência de grupos conservadores e das elites políticas que viram seus privilégios em risco. Esse contexto de descentralização foi o lócus ideal para que Putnam observasse, ao longo dos vinte anos de pesquisa, o fato de que algumas regiões se desenvolveram a despeito de outras, ele elabora uma série de perguntas norteadoras que irão ajudá-lo a investigar essa situação e que, para efeito do nosso trabalho, vamos resumir em duas: i) quais as condições necessárias para criar instituições governamentais fortes, eficazes e responsáveis, ii) “por que algumas regiões são mais cívicas que outras?”.

A análise sobre os desempenhos institucionais contrastantes permitiu que Putnam compreendesse que administrações bem-sucedidas teriam a vantagem de uma tradição cívica ancestral, que remontam do período de unificação política da Itália no início do século XIX, essa origem histórica foi responsável pelo desenvolvimento de um pensamento cívico inspirado nos princípios de liberdade e igualdade da Revolução Francesa que culminou na formação de associações civis, que ao longo do tempo também se desdobraram em cooperativas e sindicatos. Por outro lado, as experiências malsucedidas teriam como origem histórica uma tradição marcada por lealdades verticais, baixa solidariedade e confiança. Neste ponto, podemos identificar que Putnam, de maneira "cirúrgica", vai isolar as instituições como variáveis dependentes e independentes. No primeiro caso, pretende verificar até que ponto a história condiciona o desempenho das instituições. No segundo caso (instituições como variáveis independentes) vai mapear a influência que as instituições possuem sobre os atores políticos, para concluir que as instituições ao mesmo tempo em que moldam a política são condicionadas pelos contextos históricos. Mas ainda falta um elemento importante para responder as perguntas norteadoras e é com relação a esse elemento que Putnam irá elaborar o conceito de "capital social".

Desvendando o caminho da qualidade democrática, o pesquisador irá identificar que a participação dos indivíduos nos negócios públicos é a principal chave para responder suas perguntas. Desse modo, Putnam se inspira nos estudos de Tocqueville sobre associativismoe identifica que as associações são elementos importantes para desenvolvimento do civismo em uma comunidade; em outras palavras, a virtude cívica da coletividade pode levar a efeitos 
que elevem a qualidade democrática. A análise dos dados quantitativos da pesquisa de Putnam irá demonstrar que não há, necessariamente, uma relação entre desempenho econômico e desempenho democrático, porém, observou que, ao longo do tempo, as regiões com maior número de associações apresentaram índices mais elevados de participação cívica e essa foi a condição que levou ao desenvolvimento econômico das regiões, tornando os governos mais eficazes. A conclusão é clara, nas palavras do autor: "Existe uma forte correlação entre associações cívicas e instituições públicas eficazes” (p. 186), ou seja, a qualidade da democracia e o desempenho econômico estão diretamente relacionados ao grau de civismo que foi construído ao longo da história de cada região. Para conceitualizar essa situação, Putnam utiliza a ideia de capital social desenvolvido por James Coleman ${ }^{47}$.

A resposta para as perguntas norteadoras de Putnam está na cultura cívica, ou seja, em um capital social formado por um conjunto de elementos e desenvolvido ao longo da história. Ele conclui que o bom desempenho institucional está ligado ao nível de participação cívica dos indivíduos. Desse modo, os círculos virtuosos se formam a partir de elementos sociais como os elevados níveis de cooperação, confiança, reciprocidade, civismo e bem-estar coletivos, esses elementos forjam a comunidade cívica que estimula a manutenção de instituições com políticas públicas eficazes que, por outro lado, também irão promover o desenvolvimento econômico, em suas palavras: "O capital social corporificado em sistemas horizontais de participação cívica, favorece o desempenho do governo e da economia, e não o oposto: economia forte, sociedade forte, Estado forte” (p.186)

O diferente desempenho entre as regiões Norte e Sul da Itália, observado por Putnam, não foi encontrado nas estruturas das instituições, mas no contexto social no qual tiveram que operar. O que faz a democracia funcionar é a presença do capital social, desta forma, a democracia não funciona bem na ausência desse capital. Ele definiu capital social como "as redes sociais, normas de cooperação e confiança". A ausência dessas redes, ou seja, a falta de confiança e cooperação tornou ineficiente a democracia nas regiões do Sul. A trajetória histórica e os diferentes arranjos sociais também contaram para explicar a ausência ou presença desse capital social. Enfim, o bom funcionamento da democracia depende de condições que são externas a ela e, basicamente, estão na cultura de uma determinada

\footnotetext{
47 Para explicar o conceito de capital social de James Col-eman, Putnam utiliza a seguinte passagem: Assim como outras formas de capital, o capital social é produtivo, possibilitando a realização de certos objetivos que seriam inalcançáveis se ele não existisse (...). por exemplo, um grupo cujos membros demonstrem confiabilidade e que depositem ampla confiança uns nos outros é capaz de realizar muito mais do que outro grupo cujos membros demonstrem confiabilidade e que depositem ampla confiança uns nos outros é capaz de realizar muito mais do que outro grupo que careça de confiabilidade e confiança (...). Numa comunidade rural (...) onde o agricultor ajuda o outro a enfardar seu feno e onde os implementos agrícolas são reciprocamente emprestados, o capital social permite a cada agricultor realizar o seu trabalho com menos capital físico sob a forma de utensílios e equipamentos". (pg. 177)
} 
comunidade, sua capacidade para se auto organizar e promover a confiança entre seus membros.

Certamente existem falhas/questionamentos na análise de Putnam, mas o que nos interessa para efeito desse trabalho é mostrar como a ideia de cultura cívica, e sobretudo o conceito de capital social, será usada como uma chave interpretativa quando se indaga o desempenho das democracias. Assim, como não faz sentido tentar entender o associativismo sem consultar o trabalho de Tocqueville, é implausível entender a cultura cívica sem se envolver com o trabalho de Putnam.

\section{1}

\section{O conceito de cultura cívica na perspectiva de autores brasileiros}

Desse modo, observamos que a cultura cívica se estabelece mediante a as sociação dos indivíduos mediadas pelo interesse bem compreendido, confiança nas instituições e a capacidade desta em dar respostas com relação às demandas dos cidadãos. Cabe, nesse momento, indagar se há uma "validade heurística" na tradução desses conceitos para a realidade brasileira, a qual tem como aspecto fundamental as profundas desigualdades (Paiva, 2011).

Certamente a desigualdade é um grande entrave para o desenvolvimento de uma cultura cívica no Brasil. Elisa Reis (1998), ao trazer o conceito de "familismo amoral” de Banfield como chave interpretativa para o contexto da América Latina, aponta que essa questão da desigualdade associada à falta de incentivos à participação em empreendimentos coletivos, produziu um ethos próprio da chamada sociedade civil latino americano a qual, se aproximou mais de práticas de clientelismo do que de associativismo. De acordo com a autora "quando a pobreza é avassaladora e a desigualdade excessiva, a solidariedade social necessariamente se exprimirá de modos diversos, pois os valores e cognições compartilhados, que mantêm as pessoas unidas, certamente revelarão diferenças pronunciadas entre os grupos e setores”. (p.131). Deste modo, o familismo amoral é a expressão da ausência de solidariedade social em contextos de grande desigualdade.

Essa situação produz uma identidade coletiva própria, na qual, os indivíduos preferem as relações dentro de seus núcleos familiares do que ação pública em prol do interesse coletivo. O sentimento de confiança mútua é abandonado e os indivíduos recuam para o interior de sua esfera íntima. Nesse ambiente a participação em negócios públicos se dá apenas quando existe a possibilidade de ganhos materiais a curto prazo. Reis classifica o familismo como uma espécie de "desajustamento" aos novos tempos, visto que o caminho 
que levaria da tradição à modernidade não foi trilhado. Nessa situação, uma das consequências negativas seria o desenvolvimento de uma espécie de hobbesiansmo social, ou seja, um contrato social no qual o Estado seria forte o suficiente para obrigar a obediência às leis, providenciaria um mínimo de bens públicos, mas ao mesmo tempo, se caracterizaria pela falta de solidariedade cívica.

Nesse contexto de familismo, a palavra concidadão não faz sentido, e Elisa Reis pergunta: "Será que a democracia consegue se consolidar em sociedades que fracassaram do ponto de vista da integração social?" Um dos argumentos finais da autora é de que a desigualdade pode gerar entraves, mas não anula a possibilidade de construção de uma solidariedade social. Em suas palavras: "a solidariedade cívica pode diminuir ou aumentar de acordo com as modificações dos fatores econômicos e ideológicos. O caminho que leva da identidade social local para a universal, da familística à cívica não tem uma direção única” (p.133).

Essa "não direção única” nos leva ao encontro do que Maria Alice Rezende de Carvalho (2002) aponta para a necessidade de não perdermos a dimensão da cultura nas análises sociológicas sobre a democracia, visto que cada sociedade produz, ou melhor, constrói de acordo com suas características socioculturais, um tipo próprio de "cultura democrática". A cultura democrática brasileira, por exemplo, foi analisada em outra obra da autora juntamente com Luiz Werneck Vianna (2000). Nessa análise, os autores discutem o processo histórico, político e social de formação da república brasileira e apontam características que determinaram o processo de modernização da sociedade brasileira, que eles denominaram de “modernização pelo alto”.

A “modernização pelo alto" contrasta diretamente com os processos de modernização observados na sociedade norte americana e de algumas regiões da Itália que se constituíram como modelos de sociedades que se modernizaram a partir do processo de desenvolvimento de uma cultura cívica. De acordo com Carvalho e Vianna, no Brasil, a "modernização pelo alto" teve como característica a forte presença do Estado no desenvolvimento econômico e na promoção de ideias com forte apelo nacional e a "harmonia entre as classes sociais" (p.147). Contudo, Carvalho (2002) alerta para não ficarmos presos na importação de outras análises como referência, sob o risco de cairmos em um pessimismo sociológico quanto ao nosso histórico de déficit (Carvalho, 2002 apud Paiva, 2011). Por isso, apesar de o processo de modernização ter sido iniciado pelo alto, a Constituição de 1988 mobilizou uma "inclusão por baixo" que expos capacidades de integração e formas de organização que vão além do Estado e do mercado. A "inclusão por baixo" realizada no âmbito da constituinte e que 
culminou com a Constituição Cidadã foi a forma que a sociedade brasileira encontrou de forjar a democracia mesmo sem ter um estoque de capital social, para Carvalho:

“A democracia não se resume à institucionalidade do governo, mas demanda um Estado democrático de direito, sustentador das normas legais que correspondam a permanência e exigência do regime democrático, bem como que esse sistema legal seja válido, ou seja, capaz de ordenar, de fato as relações sociais, de utilidade reconhecida por todos".

Embora a Constituição de 88 tenha trazido novas possibilidades de participação cívica, a desigualdade social persistia como um imbróglio que impede à boa parte da sociedade o acesso a direitos. Desse modo, José Álvaro Moisés (1992), expõe que:

\begin{abstract}
"Passada a fase da festa da democracia, os verdadeiros problemas aparecem. Por mais desejáveis que sejam, as novas democracias revelam-se profundamente marcadas por uma distribuição desigual, não só dos bens materiais, mas também dos bens simbólicos e dos recursos de poder através dos quais elas enfrentam os conflitos societários fundamentais. Preferíveis, certamente, às alternativas autoritárias ou totalitárias, senão por outra razão, porque asseguram que a disputa por bens disponíveis pode se dar pacificamente, elas convivem, no entanto, com enormes desigualdades sociais, sexuais, raciais e etc. e com a não menos importante divisão entre governados e governantes" (p.6).
\end{abstract}

De acordo com Moisés, essa situação brasileira que envolve desigualdade e a questão do acesso de direitos, ou melhor, o não acesso aos direitos por parte dos indivíduos que são vítimas da desigualdade, poderia desencadear um desencantamento, uma apatia e até mesmo hostilidade com relação à democracia. Contudo, em outra pesquisa posterior ${ }^{48}$, esse mesmo autor, aponta que os critérios de satisfação e confiança nas instituições fazem parte de um mesmo conjunto de atitudes políticas, que mesmo quando mal avaliados não abalam a confiança na democracia. Explico melhor: para Moisés (2008) existe uma convivência contraditória entre de um lado a desconfiança dos cidadãos em instituições públicas e a insatisfação com o desempenho do regime, e por outro lado demonstram apoio à democracia. Deste modo, o pesquisador observa que as desigualdades fazem com que os indivíduos percam, ou pelo menos reduzam, sua confiança nas instituições e demonstrem a insatisfação com seu desempenho, mas não ao ponto de inviabilizarem a democracia. E é esse mesmo movimento que observamos entre os jovens que participaram da nossa pesquisa: ao perguntarmos sobre o que eles pensam a respeito da democracia, vimos que a maioria entende esse regime como "o melhor regime para viver em sociedade".

48 Democracia, desconfiança política e insatisfação com o regime - o caso Brasil (2008) 


\section{2}

\section{Resultados da pesquisa}

Nos dois gráficos a seguir, podemos observar os dados obtidos na pesquisa anterior e na pesquisa atual. É interessante observar que a noção da democracia como o melhor regime se mantém. Contudo, as opções sobre "um mal necessário" aumentaram para a rede pública e "algo que não me interessa" apresentou aumento para as duas redes. Além disso, a ideia de um regime mais forte, exposta na opção: “bom só para país desenvolvido, pois nós precisamos de um governo mais forte, apresentou uma redução, bem como para a opção "um regime que prevalece a corrupção e a violência”.

Gráfico 7.0

Sobre a democracia - Pesquisa anterior

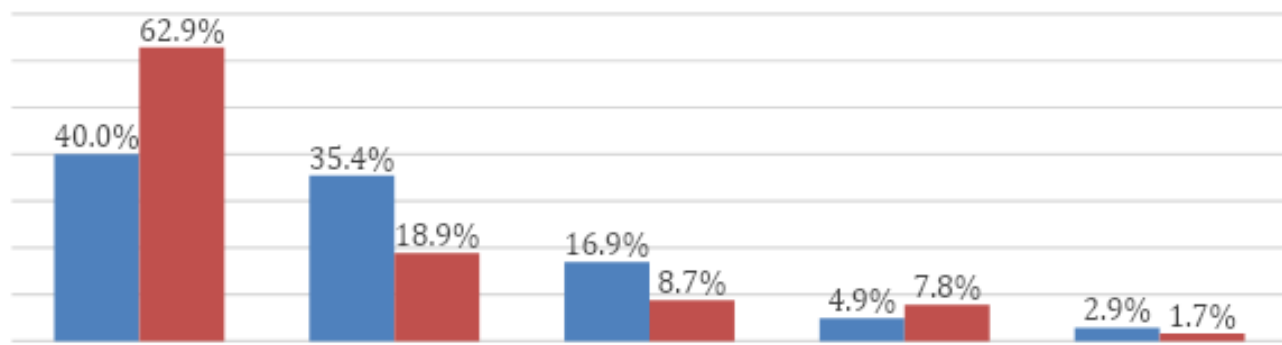

0 melhor regime Bom só para país Um regime no qualUm mal necessário Algo que não me sociedade nós precisamos de corrupção e governo mais forte violência

Público Estadual $\quad$ Particular

Gráfico 7.1

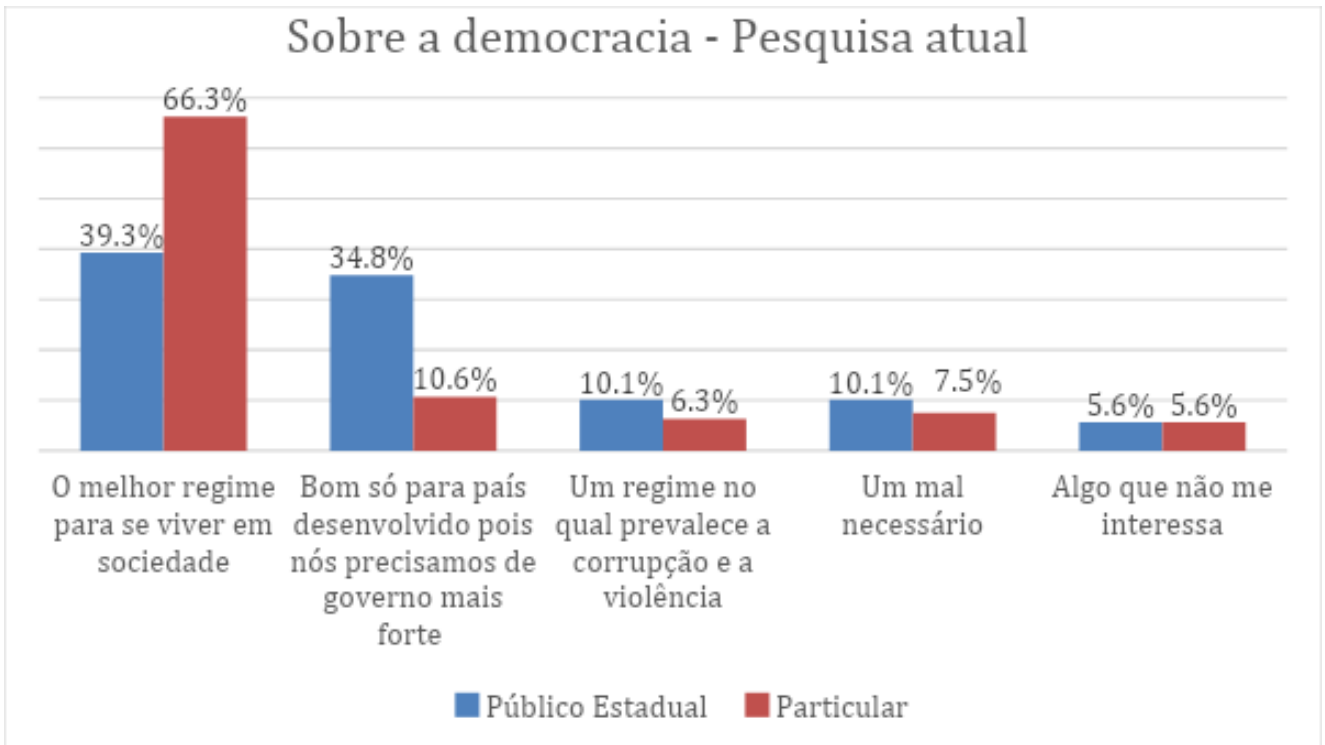


A percepção dos jovens sobre a importância do regime democrático, ao mesmo tempo em que demonstram uma análise crítica sobre esse sistema, foi observada no grupo focal realizado em um colégio particular da Zona Sul do Rio de Janeiro:

“Eu acho assim, estamos falando de democracia, que ela é boa e tudo bem, mas antes, antes de tudo, temos que fazer a distinção sobre qual tipo de democracia estamos falando. Existem tipos e tipos de democracia e é muito importante fazer a distinção sobre qual estamos falando. Qual democracia pode ajudar, ou não, o Brasil. Essa democracia representativa que está aí, eu acho que não vai ajudar. Ela reproduz um sistema eleitoral que vem de muito antes, que vem dos coronéis, então essa democracia não vai nos levar a lugar nenhum. Mas, também não acho que a democracia deve ser ignorada como solução. Eu acredito na democracia, mas uma democracia participativa direta”. (Rede privada. Zona Sul. 2019).

Dando sequência à roda de conversa, outros colegas concordaram com a declaração desse aluno, seguindo a mesma linha de pensamento, ou seja, deixando clara a importância da democracia, mas apontando a necessidade de uma mudança na questão da representatividade. Outro aluno desse mesmo colégio fez a seguinte fala:

"Desde a instauração da democracia no Brasil, ou seja, desde 1989, ela sempre serviu mais como uma ferramenta para a manutenção no poder de um grupo específico do que efetivamente como o governo de muitos e até mesmo agora, tanto tempo depois, ela parece ineficiente. Tipo eu não diria que ela foi mal projetada, mas ela serve a interesses particulares. Mesmo que a Constituição tenha sido feita direito, ninguém segue ela e não há essa intenção eu não vejo a política no Brasil com interesse de ajudar a população, mas sim com relação a enriquecer um grupo específico. A democracia gira muito em torno do voto e ela é bem mais que isso” (Rede privada. Zona Sul. 2019).

Podemos, assim, observar que dentre os jovens de nossa pesquisa a avaliação da democracia se faz mais na crítica do que na rejeição e uma boa maneira é perguntar sobre a confiança nas instituições. Seguindo a perspectiva que foi apontada anteriormente por Moisés (2008) sobre a "convivência contraditória", observamos que os jovens, apesar da confiança na democracia, não possuem o mesmo sentimento pelas instituições. Dentre as que apresentam o menor grau de confiança estão os militares e os policiais. 
Gráfico 8.0

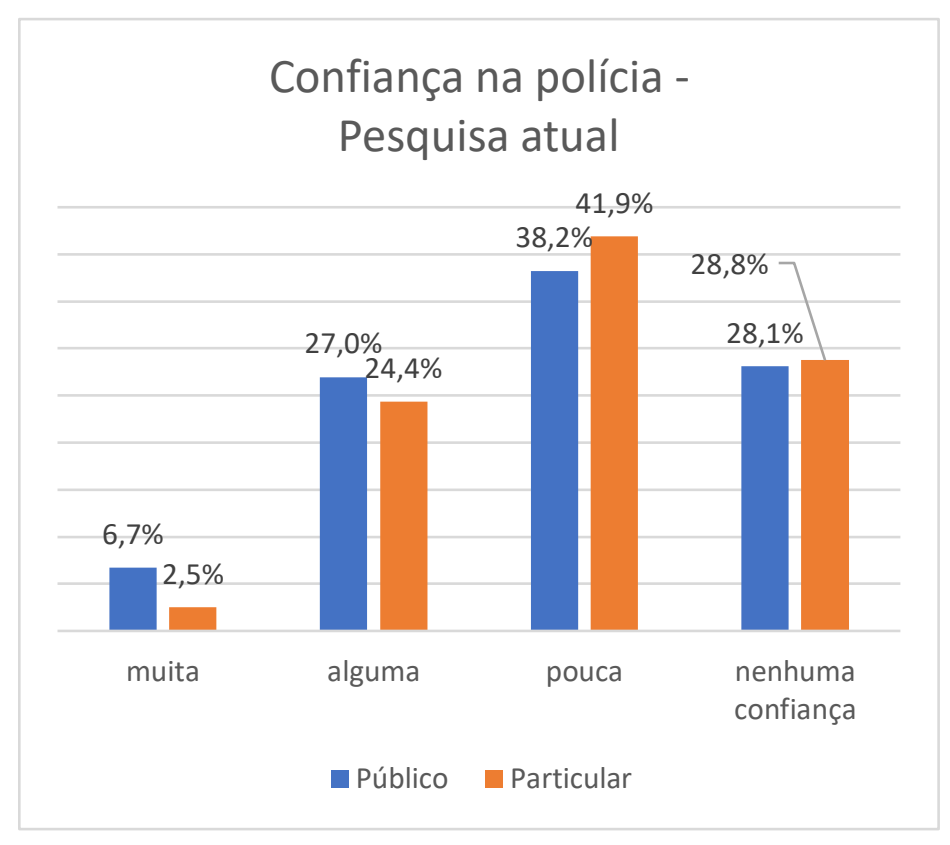

Gráfico 8.1

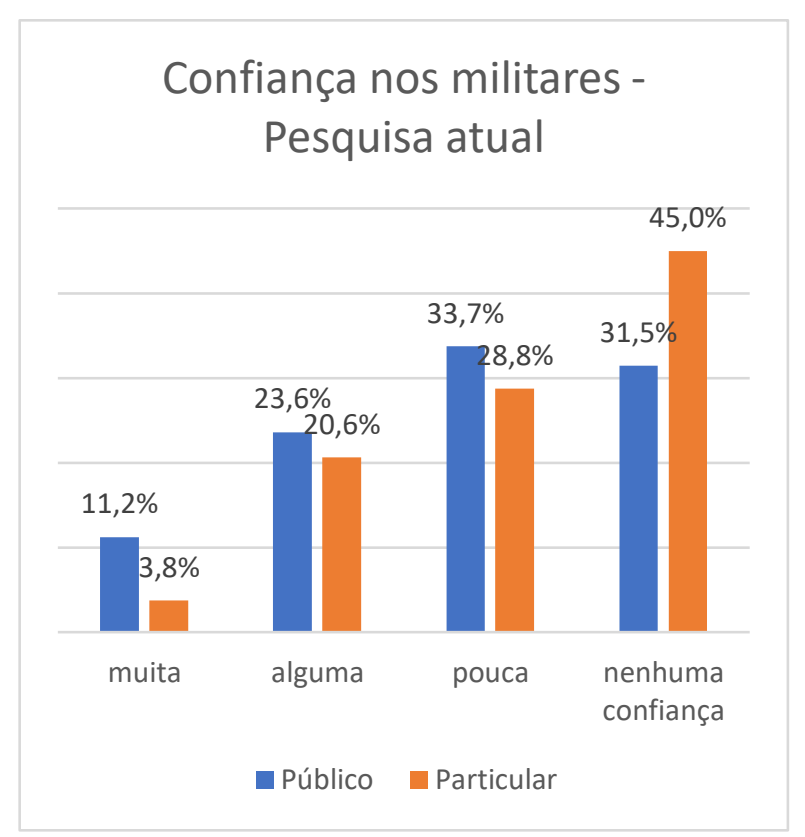

As diferenças apresentadas nas porcentagens entre a pesquisa anterior e a atual foram menores de 5\%, e por isso optamos pela apresentação (nesse quesito) apenas dos dados da pesquisa atual. Se somarmos as opções "pouca" e "nenhuma" confiança e atribuirmos a ela o rótulo "sem confiança", teremos na rede pública $66,3 \%$ e na rede particular $70,7 \%$. Por outro, se atribuirmos o rótulo "com confiança" a soma de "alguma" e "muita", teremos 26,9 $\%$ para os jovens da rede particular e 33,3\% para os jovens da rede pública. Com relação aos militares, produzimos os mesmos rótulos (sem confiança e com confiança). "sem confiança", apresentou a porcentagem de $73,8 \%$ para os jovens da rede particular e $64,2 \%$ na rede pública, já o “com confiança” apresenta uma adesão de $24,4 \%$ na rede privada e 34,8\% na rede pública. Deste modo, os jovens da rede pública apresentam uma confiança maior nessas instituições do que os da rede particular. Essa confiança maior pode nos ajudar a aventar os motivos que levaram a cerca de $35 \%$ dos jovens da rede pública a responderem que a democracia só é boa para países desenvolvidos e que aqui precisaríamos de um regime mais forte, ou seja, esses jovens confiam nessas instituições que garantiriam um Estado mais forte.

Outra instituição que não apresentou mudanças significativas no quesito confiança, entre a pesquisa anterior e a atual foi o judiciário. 
Gráfico 8.3

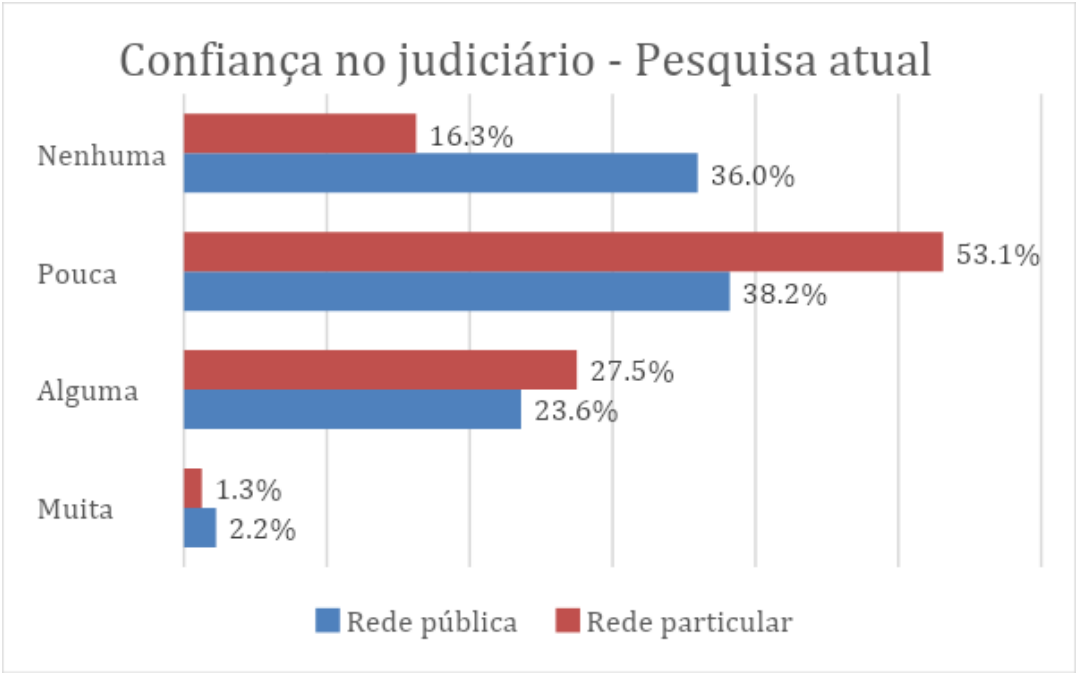

Podemos observar no gráfico acima que o maior índice está no quesito "pouca confiança" apontado por 53,1 \% dos jovens da rede particular. Se fizermos a mesma separação entre "sem confiança" e "com confiança", teremos, no caso do judiciário, que “com confiança" estão $28,8 \%$ dos jovens da rede particular e $25,8 \%$ dos jovens da rede pública. "sem confiança", temos $69,4 \%$ dos jovens da rede particular e 74,2\% dos jovens da rede pública. A porcentagem de jovens "sem confiança" no judiciário é maior tanto na rede pública quanto na rede privada.

Completando a sequência de "desconfiança crítica", temos a avaliação dos jovens sobre os partidos políticos. Neste caso, a diferença entre a primeira pesquisa e a atual, apresentou uma diferença interessante, por esse motivo, voltamos a apresentar os gráficos com os dados de cada pesquisa a fim de compará-los.

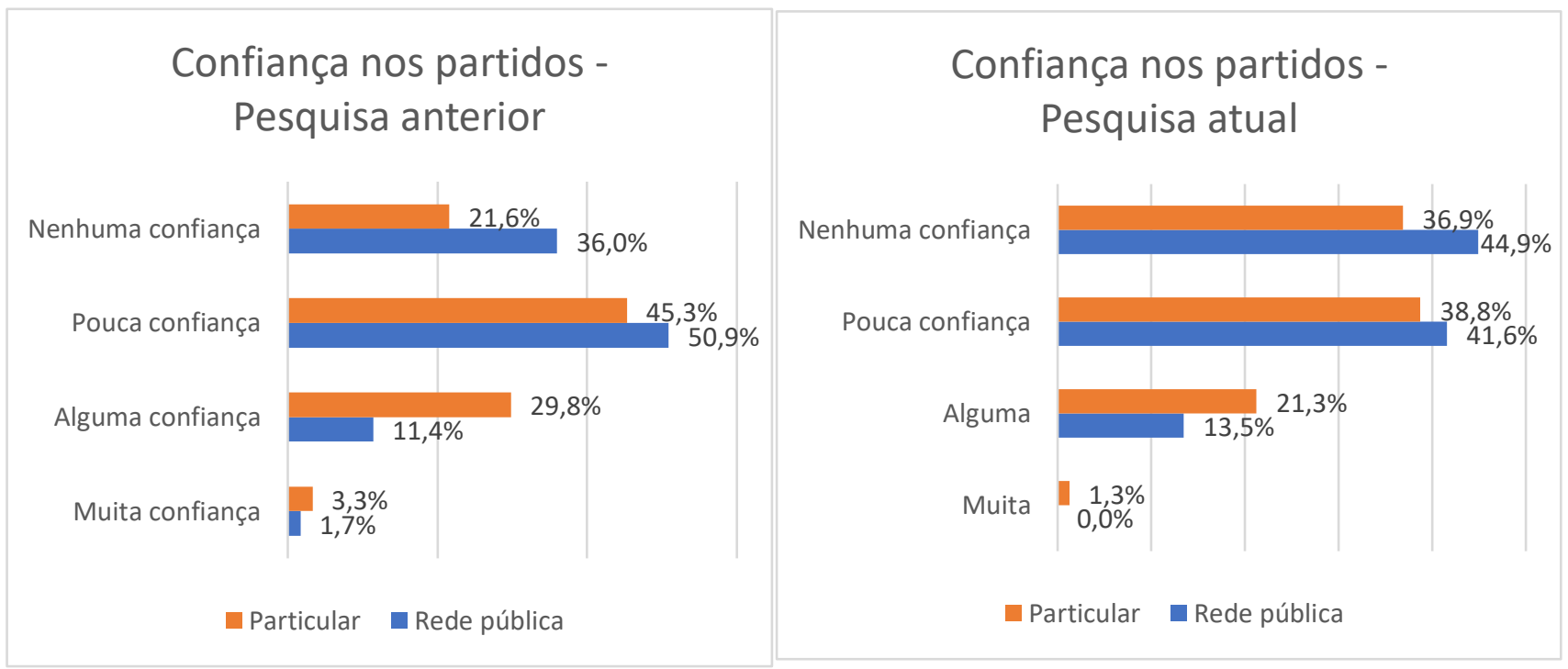


Ao compararmos os dados da pesquisa anterior com os dados da pesquisa atual, temos que a porcentagem de jovens que apresentam "nenhuma confiança" aumentou em ambas as redes, enquanto todas as outras opções apresentaram redução, chegando a apresentar $0 \%$ no quesito "muita confiança" para os alunos da rede pública. O motivo para essa "descrença" aparece na fala de uma jovem de rede particular:

"Teve um afastamento da política com o cidadão comum porque a gente vê a política na figura do político, do partido, mas eles mudam de partido. Mudam no início pra surfar na onda de algum candidato que vai ganhar e depois mudam pra fazer lobby e depois mudam de novo pra ter coeficiente eleitoral. Confiar como?" (Rede privada. Zona Sul. 2019).

A avaliação sobre os políticos também apresentou bastante diferença entre a primeira pesquisa e a atual.

Gráfico 9.0

Avaliação sobre os políticos Pesquisa anterior

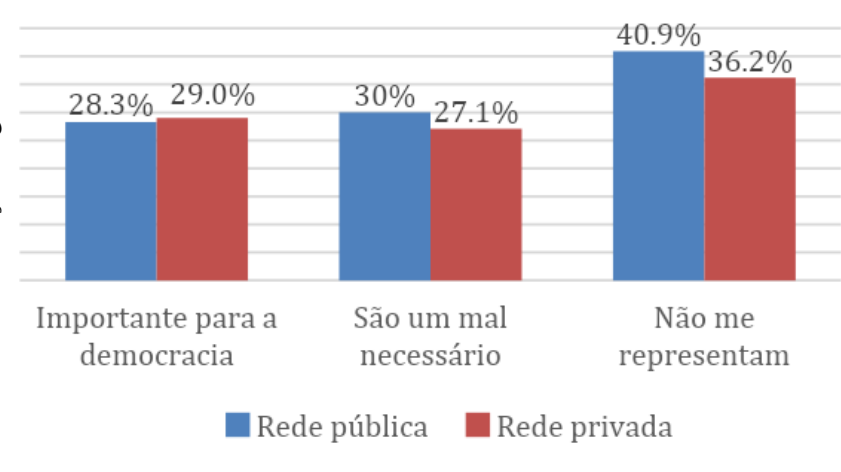

Gráfico 9.1

\section{Avaliação sobre os políticos -} Pesquisa atual

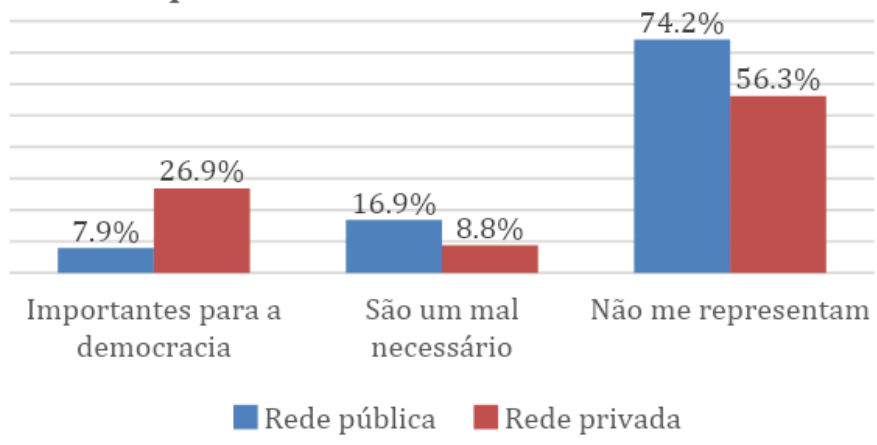

Enquanto na primeira pesquisa cerca de $30 \%$ dos jovens apontavam que os políticos eram importantes para a democracia, na pesquisa atual apenas os jovens da rede privada mantiveram uma porcentagem próxima a anterior, pois para os jovens da rede privada apenas 7,9\% acreditam que os políticos são importantes para democracia o que representa uma queda de 20,4\%. A opção "são um mal necessário" apresentou uma redução entre os jovens das duas redes, sendo maior para os jovens da rede privada. Para 74, $2 \%$ dos jovens da rede pública e para 56,3\% dos jovens da rede privada, os políticos não os representam. Essa baixa confiança com relação aos políticos pode ter relação com a falta de confiança nos partidos, com os inúmeros escândalos de corrupção, mas também pode ser relacionada à baixa representatividade do perfil dos candidatos. Segundo dados do Tribunal Superior Eleitoral 
$(\mathrm{TSE})^{49} 69,1 \%$ dos candidatos que disputaram as eleições em 2018 eram homens, 52,6\% se declararam brancos, 52,9\% declararam ter ensino superior completo e idade média de 48 anos. Todas essas porcentagens se encontram em desacordo com a realidade brasileira, visto que, segundo o IBGE ${ }^{50}, 51,8 \%$ da população brasileira é formada por mulheres, $55,9 \%$ da população é negra, apenas $15,3 \%$ alcança o ensino superior e a população jovens (até 29 anos) representa $42,3 \%$ da população. Ou seja, podemos identificar que o perfil de indivíduo que tem se apresentado como candidato a cargos políticos não se aproxima das características mais evidentes da população e esse pode ser um dos motivos que contribuem para que os jovens apontem esses candidatos como alguém que não os representam. Mas o argumento do relato do jovem acima, do afastamento da política do cidadão comum, acrescenta um ingrediente importante.

As respostas sobre a atuação dos políticos foi mais uma das mudanças observadas pela pesquisa atual e corrobora com o resultado anterior.

Gráfico 9.2

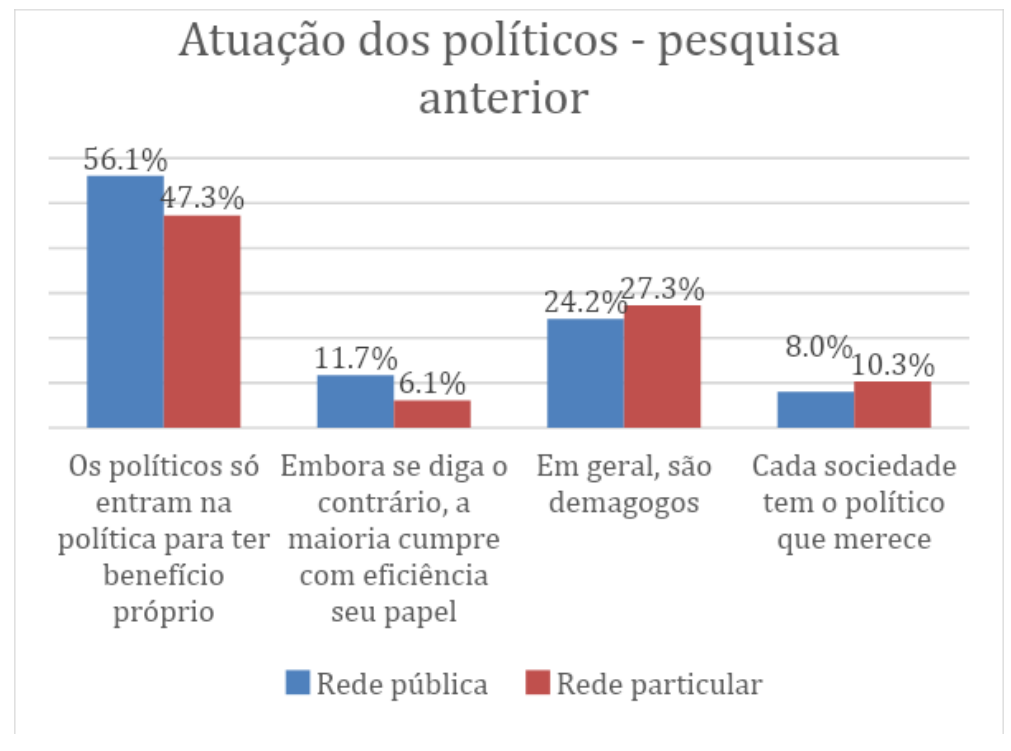

\footnotetext{
49 http://www.tse.jus.br/imprensa/noticias-tse/2018/Julho/perfis-de-candidatos-status-de-candidaturas-e-prestacoesde-contas-eleitorais-de-2018-sao-disponibilizados-na-internet

50 https://www.ibge.gov.br/estatisticas/sociais/populacao.html
} 
Gráfico 9.3

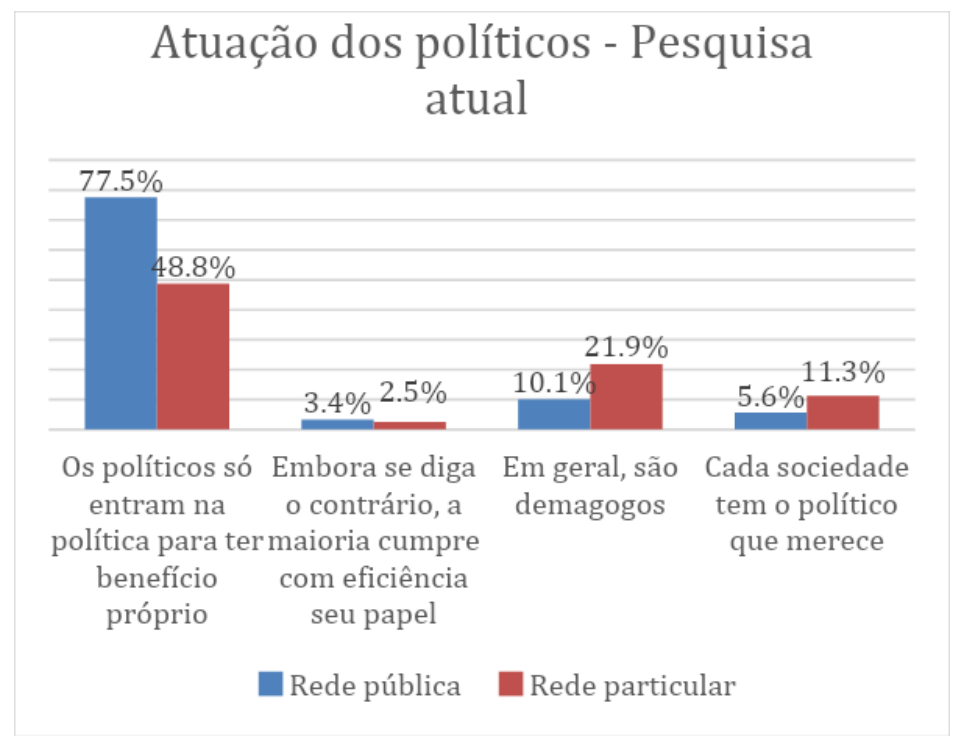

Enquanto na primeira pesquisa, pelo menos, $11,7 \%$ dos jovens da rede pública e $6,1 \%$ dos jovens da rede particular consideram que "embora se diga o contrário, a maioria cumpre com eficiência seu papel", na pesquisa atual, as porcentagens das respostas dadas pelos jovens das duas redes não chega a 10\%. Por outro lado, entre os jovens da rede pública que acreditam que "os políticos só entram na política para ter benefício próprio subiu $21,4 \%$. A visão crítica sobre a atuação dos políticos também foi apresentada pelos jovens nos grupos focais.

“A gente não se identifica e tem um distanciamento completo e muita gente pensa assim. Os politicos aparecem na eleição e depois não servem pra mais nada. Eu sei que não deveria ser assim. A política está em todos os lugares, está quando você vai pegar um ônibus, quando precisa de um hospital público, quando tem que ter segurança, mas na prática não é assim. As pessoas não fazem o link entre o que o político faz e a vida delas como está." (Rede privada. Zona Sul. 2019).

Os critérios para a escolha dos candidatos foi uma das questões abordadas no questionário e que podem nos ajudar a identificar a análise crítica dos jovens sobre a escolha política. 
Gráfico 10

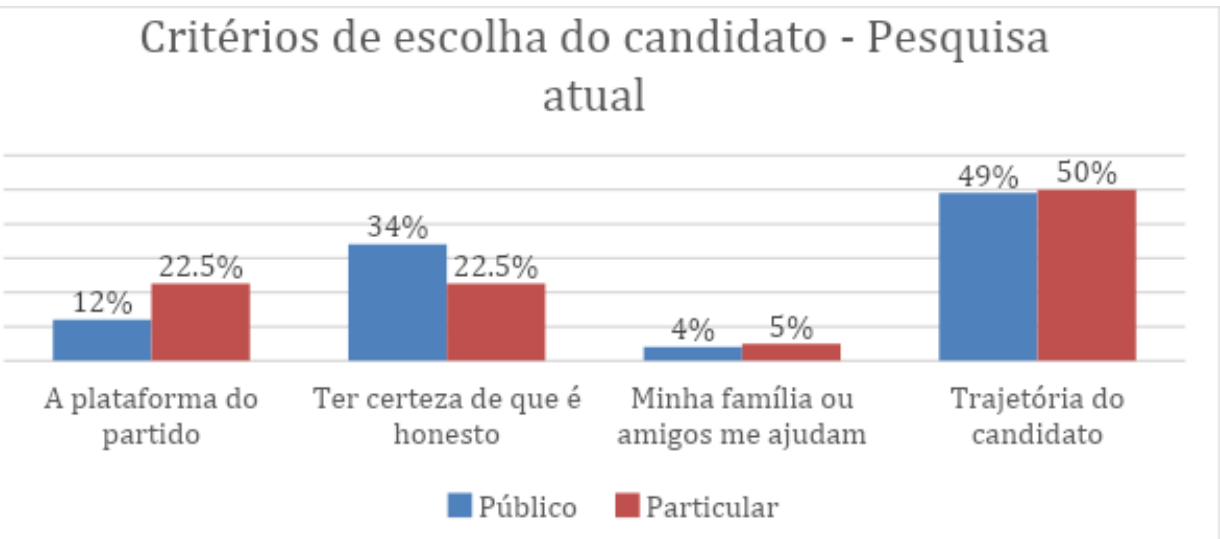

A utilização do critério de "trajetória do candidato" pela maioria dos jovens, ao invés da influência de amigos ou da família, pode nos dar pistas sobre a noção que possuem sobre a importância de uma trajetória política bem sedimentada, além da autonomia desses jovens para realizar suas escolhas políticas.

Com relação à autonomia e seguindo um dos aspectos que compõem a formação do

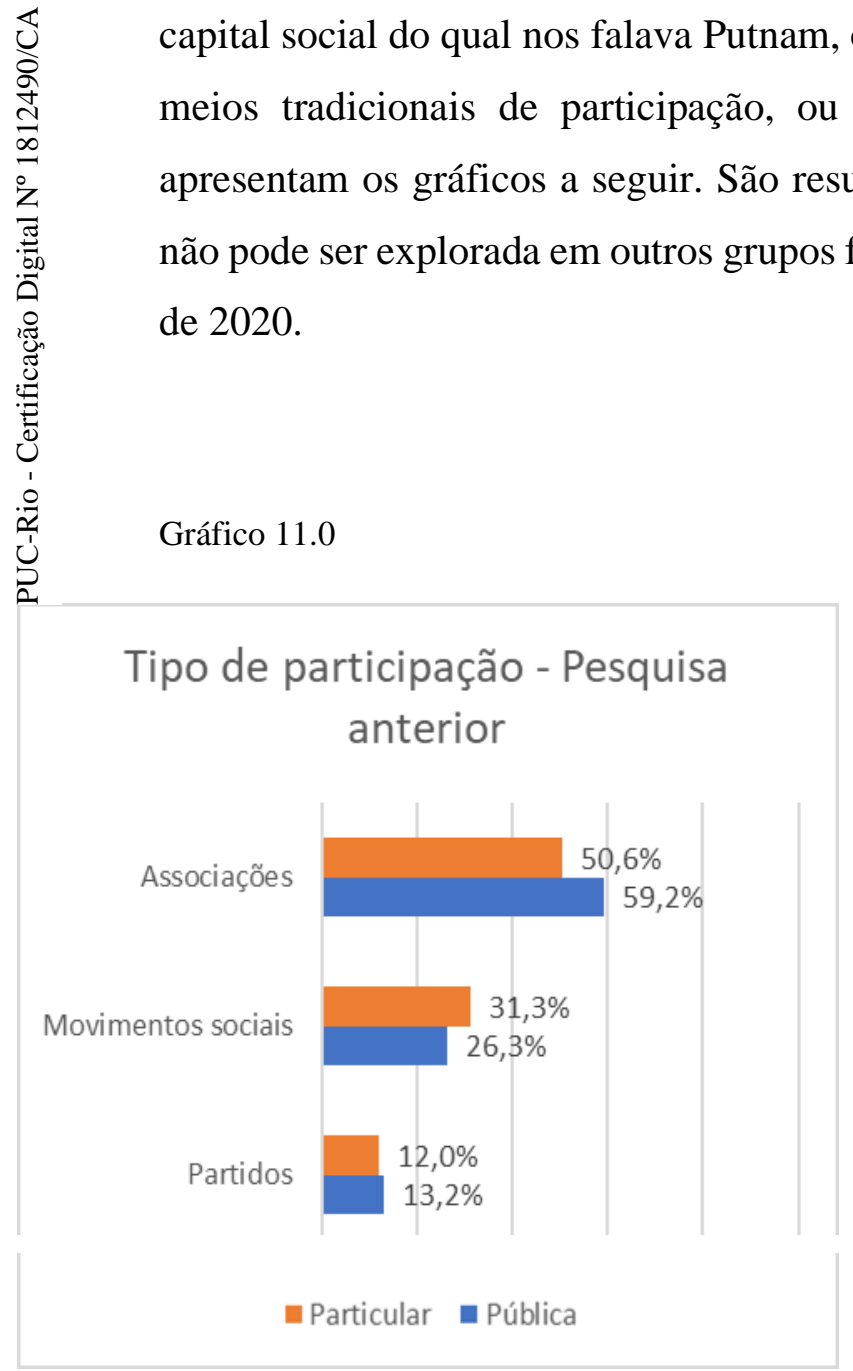

Gráfico 11.1

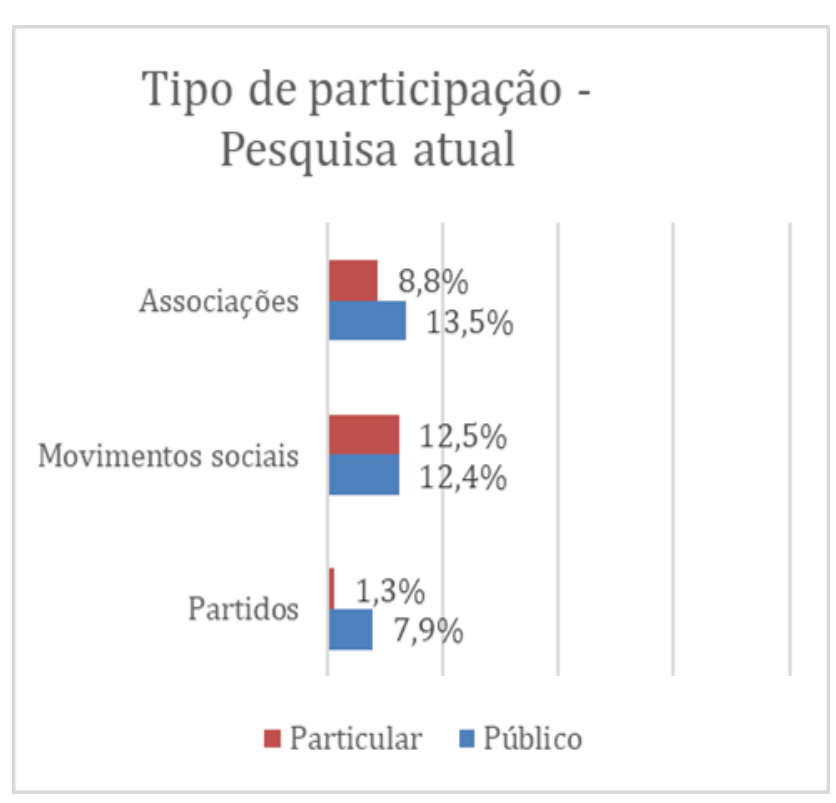


Observamos que desde a primeira pesquisa os índices de participação se mostravam baixos e na segunda pesquisa essa tendência de redução se acentua em todas as modalidades de participação.

Com relação a essa dimensão da participação dos jovens estudantes, cabe nesse momento lembrar um fenômeno que ocorreu em diversas escolas do país no ano de 2016 e que ficou conhecido como "ocupações". Iniciado em escolas de São Paulo, a estratégia do movimento formado, principalmente, por alunos do ensino médio, consistia em literalmente ocupar a escola ao impedir a entrada de funcionários, professores ou qualquer pessoa que se mostrasse contrária à ocupação. O objetivo dos jovens que iniciaram as ocupações era protestar contra a "reorganização escolar" proposta pelo governo de São Paulo e na medida que a estratégia foi se espalhando por outras escolas de outras regiões do país, a agenda de reivindicações foi sendo ampliada, mas sempre com foco na melhoria da qualidade da educação e da infraestrutura das escolas. As ocupações tiveram uma duração média de 60 dias e foram replicadas em mais de 1.000 escolas em todo Brasil ${ }^{51}$. As ocupações deixaram como legado uma nova estratégia de manifestação dos jovens estudantes, visto que boa parte das reivindicações foram atendidas. Contudo, podemos dizer que esse legado se concentrou nessas conquistas e que o movimento se encerrou quando os jovens que protagonizaram essas ações concluíram o ensino médio. No momento em que a nossa pesquisa retomar as atividades de campo incluiremos em nosso roteiro dos grupos focais um tópico sobre as ocupações para buscar entre jovens algum tipo de memória desse movimento, mas até este momento, nos grupos focais que foram realizados, não houve qualquer menção ao movimento de 2016.

Com relação aos gráficos apresentados anteriormente (gráfico 11.0 e gráfico 11.1) as associações foram as que apresentaram a maior redução, seguida pelos partidos e movimentos sociais. A porcentagem de jovens que declararam não participar, tanto na primeira, quanto na segunda pesquisa, se mantiveram em torno de $70 \%$. As duas principais causas para a não participação em atividades extracurriculares foi apresentada nos grupos focais, conforme as falas a seguir: A primeira é com relação ao medo da violência:

\footnotetext{
51 Para mais informações sobre esse tema ver a dissertação de Mariana Junqueira Camasmie: “O movimento de ocupação das escolas e as novas formas de fruição da juventude escolarizada nas classes populares do Brasil. In: https://www.maxwell.vrac.puc-rio.br/36217/36217.PDF
} 
“Eu não participo de grêmio, não participo de grupo, de protesto de nada porque minha mãe não deixa, então eu não posso ir a manifestação, nada disso porque ela tem medo, acha que vai acontecer alguma coisa, então eu prefiro ficar na minha e não participar mesmo”. (Rede privada. Zona Sul. 2019).

A segunda maior causa apresentada para a não participação e, atividades extracurriculares é a necessidade de passar mais tempo estudando, tendo em vista a proximidade das provas do Enem e vestibulares:

“Eu até já participei. Já fui do grêmio, já fiz parte do projeto social que tem aqui na escola, mas do meio do ano passado pra esse eu fui deixando, porque meu tempo todo agora é estudando pro Enem, vestibular mesmo ...essas coisas. Não dá pra fazer junto”. (Rede privada. Zona Sul. 2019).

Nesse momento, cabe-nos colocar alguns dados que se encaixam nesse momento sobre a relação dos jovens com a internet, visto que quando o assunto é participação, muitos deles levantam a possibilidade de algum tipo de engajamento no ambiente virtual. Em nossa primeira pesquisa, essa dimensão da internet não foi cogitada, porque na época não era algo tão comum, mas nessa segunda pesquisa, adicionamos algumas perguntas ao questionário original, justamente para iniciarmos um mapeamento sobre essa relação dos jovens com a internet e para averiguar se, de alguma forma, esse ambiente virtual poderia ser "responsabilizado" por eventuais mudanças nas percepções dos jovens.

A primeira pergunta sobre internet e que foi adicionada ao nosso questionário foi sobre as atividades que os jovens praticam mais na internet. A partir das informações fornecidas por eles, montamos os seguintes gráficos:

Gráfico 12.1 - Dados da pesquisa atual

Gráfico 12.1 - Dados da pesquisa atual

Uso da internet - Rede Pública

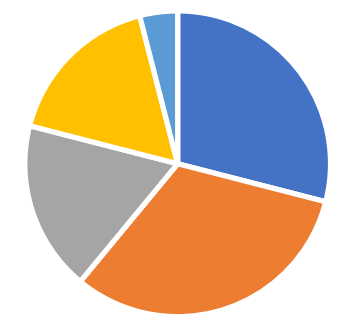

- Entretenimento

- Conversa aplicativo
Uso da internet - Rede Privada

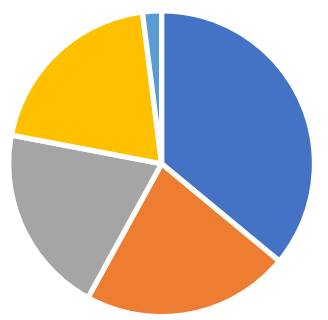

- Entretenimento - Conversa aplicativo

- Informações aleatórias — Pesquisa escolar

- e-mail, compras, trabalho 
As atividades realizadas na internet pelos jovens da rede pública e da rede privada são muito parecidas, sendo a principal atividade a conversa por meio de aplicativos, seguida do entretenimento que está relacionado aos jogos, redes sociais e plataformas de streaming de filmes e séries. Em terceiro lugar está o uso da internet para o uso de busca de informações que denominamos de "aleatórias", tais como resultados de jogos de futebol, previsão do tempo, notícias sobre famosos, dentre outras. Essas informações são diferentes daquelas que estão em quarto lugar no uso da internet para esses jovens que é a busca de informações para a realização de pesquisas escolares. As atividades menos comuns entre esses jovens na internet são: verificação de e-mail, compras e motivos de trabalho.

O motivo pelo qual, inserimos essas informações aqui foi porque inicialmente tínhamos uma hipótese de que a interação desses jovens nas redes sociais poderiam causar algum tipo de mudança com relação às percepções políticas e de confiança nas instituições e, de fato, durante os grupos focais, o assunto sobre as eleições de 2018, fake News, grupos de WhatsApp e redes sociais foram apontados. Além disso, algo que não estava em nossas hipóteses também foi identificado, também nos grupos focais, que é denominada "militância digital”, ou seja, uma forma de participação política por meio da internet. Por isso, quando observamos nos dados sobre participação que os percentuais de jovens engajados em canais de participação tradicionais, tais como movimentos sociais e partidos, haviam diminuído entre a pesquisa anterior e a atual, nos perguntamos se essa participação não teria migrado para o formato virtual.

Desse modo, temos que, de acordo com os jovens entrevistados, a maior parte do tempo gasto na internet se concentra em conversas por aplicativos, jogos, séries e busca de informações. Até o momento, não surgiu nenhum dado que possa confirmar essa migração na forma de participação. Contudo, nos grupos focais, os jovens deixaram claro que essa é uma possiblidade, mas não irrefletida, visto que entendem bem as armadilhas da "militância virtual".

Eu considero a internet uma faca de dois gumes. As pessoas daqui da escola, por exemplo, acabam se contentando com pouco. Elas pensam: ah! postei uma coisa no Instagram, coloquei interesse no evento, pronto! Fiz minha parte. O apoio é só virtual". (Rede privada. Zona Sul. 2019).

Outro aluno tenta explicar a "lógica" por trás dessa participação virtual:

"Dai que está todo mundo conectado. Eu fico com o meu celular 24 horas por dia. Tem um lado negativo, porque me dá um conforto e pode até me impedir de agir de forma concreta, mas por outro lado, olha só o poder de alcance da internet, ela tem um super poder de alcance! Eu escrevo algo que estou pensando aqui e todo mundo pode ficar sabendo, isso é bom, muito bom, mas é meio marginal se comparado a ação concreta." (Rede privada. Zona Sul. 2019). 
Uma aluna amplia o debate e faz uma comparação com a forma de mobilização dos anos de chumbo e o atual numa reflexão sobre as potencialidades e as armadilhas da mobilização pela via virtual:

“As redes sociais, de uma forma geral, nos dão acesso a muita coisa que a gente não teria acesso. Eu acho que ela nos deixa menos suscetível à bolha em que a gente vive, ela traz a informação. Nos anos da ditadura militar mesmo, nos anos de chumbo, pra se engajar politicamente você teria que ler livros, frequentar grupos de troca de conversa, hoje em dia, você vê um vídeo, as notícias em tempo real, uma entrevista, uma palestra até mesmo os memes, isso facilita, faz o conteúdo circular, mas tem que saber que conteúdo é esse... se está certinho, se é verdade, de onde vem" (Rede privada. Zona Sul. 2019).

Diante dessas informações, ficou claro que ainda não há, pelo menos dentre os jovens pesquisados, um movimento formal que indique que a redução no número de jovens engajados em canais tradicionais de participação, migrou para a "militância virtual”, contudo pudemos averiguar que eles estão bastante cientes dos perigos e das potencialidades dessa ação.

Mas voltando para um quesito importante para a construção de capital social que constitui a cultura cívica, perguntamos aos jovens, qual o sentimento que eles têm pelo país. Gráfico 13.0

\section{Sentimento pelo país - Pesquisa anterior}

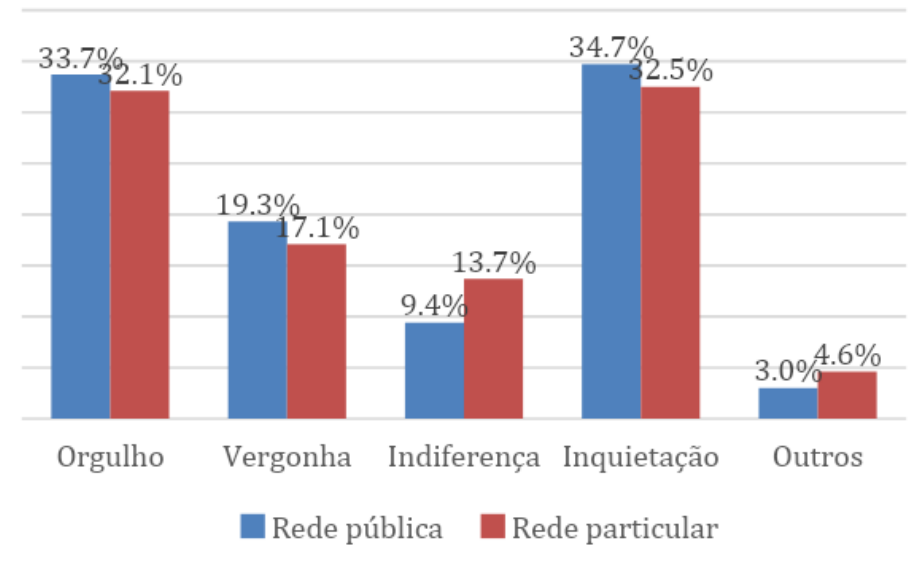


Gráfico 13.1

\section{Sentimento pelo país - \\ Pesquisa atual}

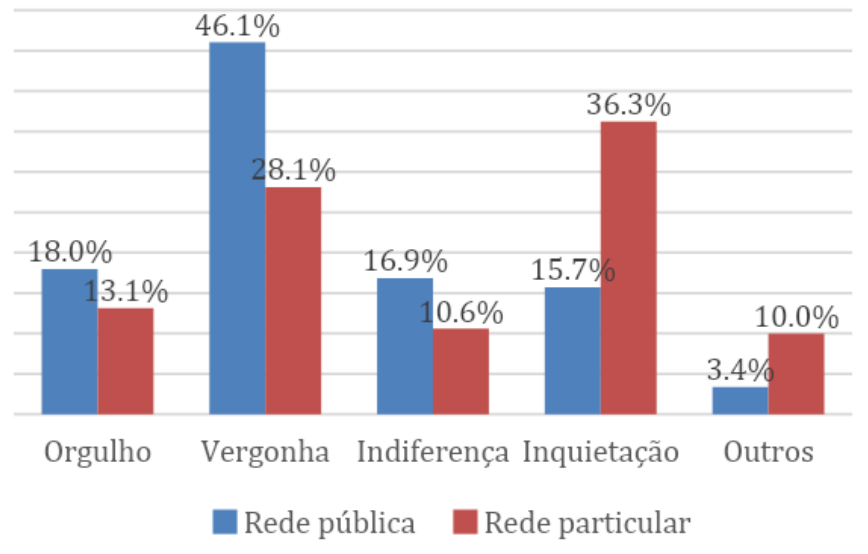

Podemos observar que as percepções sobre o sentimento pelo país mudaram em todos as opções. O sentimento de “orgulho" que apresentava uma porcentagem muito próxima entre os jovens da rede pública e da rede particular, numa média de $30 \%$, teve uma redução de cerca de $17 \%$. O sentimento de inquietação caiu também, mas apenas entre os jovens da rede pública. Entre os jovens da rede particular esse percentual apresentou um pequeno aumento. O dado que chama mais atenção é o aumento no índice de "vergonha". Na primeira pesquisa, essa opção não chegava a $20 \%$ das respostas, e na pesquisa atual, tem $46,1 \%$ das respostas dos jovens da rede pública e $28,1 \%$ dos jovens da rede particular. Deste modo, temos que, para os jovens da rede pública, o principal sentimento com relação ao país é a "vergonha" com quase 50\%, seguida de "orgulho" com 18\%. Para os jovens da rede privada a "inquietação" é o maior sentimento com 36,3\%, seguido de "vergonha" com 28,1\%. Aqui apontamos uma fragilidade e uma potencialidade desse momento da pesquisa. A fragilidade consiste na situação de não podermos analisar esses dados com mais acuidade pela ausência de grupos focais realizados na rede pública. A potencialidade está na ampliação das hipóteses, visto que, assim que retornarmos ao campo, poderemos identificar quais os aspectos que compõem as categorias "vergonha", "orgulho" e "respeito" na percepção dos jovens.

Para tentarmos dimensionar um pouco melhor essa mudança, observaremos as respostas que foram dadas para três perguntas a seguir. Estas, assim como a questão sobre a internet, vista anteriormente, também não estavam no questionário original. Elas foram adicionadas no questionário da pesquisa atual para que, por meio delas, possamos identificar a noção de pertencimento desses jovens com relação ao país. As perguntas eram as seguintes: i) Se tivesse oportunidade, iria viver em outro país? a) nunca; b) definitivamente, c) 
temporariamente para estudo ou trabalho. ii) Em qual país gostaria de morar? iii) Por que você gostaria de viver neste país? a) porque lá as pessoas são mais respeitadas, b) porque lá existe mais oportunidade de trabalho, c) porque lá existe mais segurança.

Gráfico 14.0 - Dados da pesquisa atual

\section{Morar em outro país}

Rede pública

$2.2 \%$

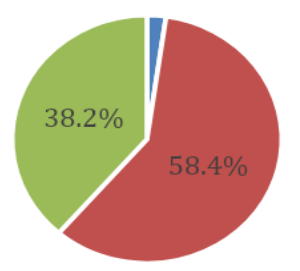

- Nunca

Definitivamente

- Temporareamente para estudo ou trabalho
Gráfico 14.1 - Dados da pesquisa atual

Morar em outro país

Rede particular

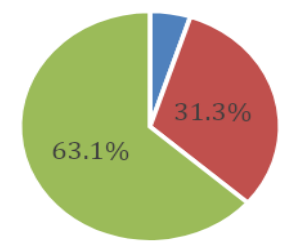

- Nunca

Definitivamente

- Temporareamente para estudo ou trabalho

Dentre os entrevistados, apenas 2,2\% dos jovens da rede pública disseram que nunca morariam em outro país e dentre os jovens da rede particular, esse percentual ficou em $5 \%$. Chama a atenção a questão do morar definitivamente e o temporariamente. Enquanto a maioria dos jovens da rede pública gostaria de morar em outro país definitivamente, a maioria dos jovens da rede particular gostaria de morar em outro país em caráter temporário.

Os dois países mais citados entre os jovens que gostariam de morar definitivamente em outro país foram Estados Unidos e Canadá, e os motivos para deixar o Brasil definitivamente podem ser observados nos gráficos a seguir.

Gráfico 14.2 - Dados da pesquisa atual

\section{Motivos - Rede pública}

$17 \%$

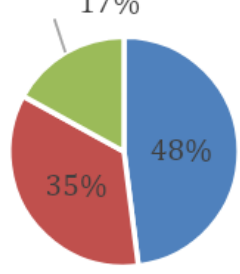

- Porque lá as pessoas são mais respeitadas

- porque lá existe mais oportunidade de trabalho

porque existe mais segurança 
Gráfico 14.3 - Dados da pesquisa atual

Motivos - Rede particular

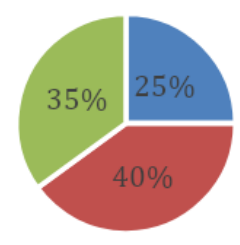

— Porque lá as pessoas são mais respeitadas

- porque lá existe mais oportunidade de trabalho

porque existe mais segurança

Enquanto a maioria dos jovens da rede particular se predispõe a deixar o Brasil motivados por uma oportunidade de emprego, os jovens da rede pública, em sua maioria, fariam essa mudança de país em busca de respeito.

Essas diferentes percepções nos levam a uma série de questões que não se esgotam nessa dissertação. Deixamos esses dois gráficos finalizarem esse item, mas não a pesquisa “Juventude, Cultura Cívica e Cidadania" que ainda terá um longo caminho pela frente, tendo em vista o banco de dados que foi formado e as inúmeras questões abertas e provocações, inclusive, essa última aqui apresentada pela percepção dos jovens sobre o que os motivaria a deixar seu país de origem: melhores oportunidades e respeito.

Observamos que a cultura cívica é construída a partir de um conjunto de aspectos: noção de igualdade entre os indivíduos pertencentes a uma determinada sociedade, disposição para participação na esfera, noção de pertencimento que produz o sentimento de nação, confiança nas instituições e cooperação são alguns exemplos. Mas como esses aspectos são constituídos? Tocqueville nos oferece pistas ao observar as associações nos Estado Unidos e Putnam nos apresenta o capital social como resposta. No Brasil o tipo de formação do Estado impactou na construção da esfera pública e na disposição da sociedade para sair da esfera privada em prol de um bem comum. Mas não em definitivo: a Constituição de 88 lança luz sobre o protagonismo social sufocado pelos anos de governos autoritários e novas dinâmicas sociais conduzem a sociedade para outras formas de participação na esfera pública, apesar de a desigualdade ainda ser uma marca que gera constrangimentos e impede maior participação no arranjo democrático. Os jovens da nossa pesquisa demonstraram uma percepção crítica sobre essa relação entre democracia e desigualdade. Ainda que avaliem positivamente a democracia, apontam para uma crescente desconfiança nos partidos políticos. Nos grupos focais esses jovens falaram sobre um "ciclo vicioso" presente na 
atividade política que faz com que os políticos se dediquem mais às eleições do que em produzir ações em favor do bem comum. Como saída para esse "ciclo vicioso", sugerem novo tipo de democracia mais participativa e menos representativa, visto que a opinião que apresentam sobre os políticos é a de que esses só entram na política para ter benefício próprio. Embora não participem expressivamente de atividades extracurriculares, o que poderia indicar grau de associativismo, os jovens se mostram ativos nas redes sociais e nas mobilizações que surgem nesse ambiente. Contudo, são críticos ao que chamam de "militância digital" que seria uma espécie de engajamento com validade virtual e de pouco impacto concreto. Eles não estão satisfeitos com o país. Para os jovens da rede pública essa insatisfação gera sentimento prevalecente de vergonha, enquanto para os jovens da rede particular, produz inquietação. A consequência desses sentimentos produz a vontade de viver em outro país. A porcentagem dos jovens que sentem vergonha é a mesma dos que gostariam de viver em outro país definitivamente, enquanto o outro grupo, ou seja, os que apresentam inquietação, deixaria o país apenas temporariamente para estudo ou trabalho. Esses foram alguns dos dados informados pelo campo e apresentados nesse capítulo. Embora não sejam dados definitivos, nos ajudam a construir pistas para que possamos formular hipóteses sobre a percepção dos jovens com relação aos aspectos que compõem esse conceito tão importante para o desenvolvimento de uma democracia consolidada que é a cultura cívica. 


\section{5. \\ Conclusão}

O objetivo desse trabalho foi realizar uma comparação entre os dados da pesquisa Juventude, cultura cívica e cidadania, realizada em 2004 e os dados obtidos a partir de 2019, ou seja, 15 anos depois. Para tal tarefa seguimos a mesma metodologia da primeira pesquisa, estabelecendo a escola como campo e os jovens estudantes da rede pública e privada de três regiões do Rio de Janeiro (Zona Sul, Barra da Tijuca e Tijuca) como público alvo. Além disso, a aplicação de questionários e a realização de grupos focais formaram a nossa base de dados. Na pesquisa atual, diante da distância de 15 anos da primeira, surgiram três hipóteses para possíveis mudanças e permanências na percepção dos jovens. A primeira hipótese, com relação à permanência nas percepções, está relacionada a consolidação democrática do país, dado os 30 anos de estabilidade democrática. As hipóteses para as possíveis mudanças se concentraram no advento da internet, sobretudo no uso das redes sociais pelos jovens, além da inserção da Sociologia como disciplina obrigatória no ensino médio. Contudo, o nosso campo que estava com prazo bem apertado devido ao cronograma que deveria contemplar o prazo do mestrado, foi afetado de forma mais lancinante com a situação da pandemia de Covid-19 que suspendeu as aulas presenciais e nos impossibilitou de realizar aplicações de questionários nas escolas públicas "de excelência" e os grupos focais nas escolas públicas estaduais. Com o campo, inevitavelmente, suspenso, tabulamos os dados que tínhamos colhido até aquele momento e tomamos duas decisões. A primeira era que faríamos as comparações entre as escolas públicas estaduais e particulares, a segunda era a de que traçaríamos um percurso teórico maior, com o objetivo de sedimentar as bases conceituais sobre os temas que norteiam a pesquisa: juventude, cultura cívica e cidadania. Desse modo, cada capítulo desse trabalho apresentou como abertura uma base de discussão teórica dividida entre clássicos gerais e clássicos específicos, digo melhor, uma literatura geral que apresentou o conceito e uma literatura específica que problematizou o conceito dentro da realidade brasileira. Os dados da pesquisa, que estamos considerando como provisórios, foram apresentados em um tópico a parte, mas em contínuo diálogo com a teoria apresentada. Mas afinal, quais foram as mudanças e as permanências percebidas, até aqui, por nossa pesquisa?

Inicialmente identificamos a permanência do que denominamos, na primeira pesquisa, de "simetrias" 52 . Eles ainda consideram que ser jovem "dá muita insegurança" e apresentam

\footnotetext{
52 Por simetrias entendemos as percepções dos jovens das redes públicas e privadas que se aproximam.
} 
um nível expressivo de confiança em três instituições: família, escola e universidade. A confiança na universidade é tão animada que uma média de $90 \%$ desses jovens respondeu que pretendem prestar vestibular e (sobretudo) para universidades públicas (80\%). Contudo, essa simetria é atravessada pela realidade da desigualdade que dividirá, de um lado, os jovens da rede privada e de outro, os da rede pública, visto que para esses últimos o acesso à universidade é atravancado por uma série de desafios que vão desde as péssimas condições de infraestrutura das escolas públicas, passando precarização do trabalho do professor, pelos baixos investimentos direcionados para a educação pública, pela evasão, isso para falar de apenas alguns dos fatores que irão confluir no baixo índice de aprovação desses nos vestibulares para universidades públicas. Essa situação se configura ainda mais dramática quando constatamos que $70 \%$ dos jovens alunos de ensino médio do Rio de Janeiro pertencem à rede pública.

Outras simetrias que se mantiveram foram as que indicam pouca ou nenhuma confiança dos jovens em quatro instituições: polícia, militares, judiciário e partidos políticos. Com relação aos políticos, as percepções também se mantiveram simétricas, visto que para a maioria, os políticos não os representam ou só entram na política para conquistarem benefícios próprios. Contudo, essa baixa confiança não indica uma ruptura com o sistema democrático, pois $82 \%$ consideram o voto um direito importante e $70 \%$ pretendem tirar o título antes dos 18 anos, ou seja, quando ainda é facultativo. Além disso, a democracia é apontada como o melhor regime para se viver em sociedade.

As percepções que mudaram de uma pesquisa para outra começam pela noção do que é ser cidadão. Na primeira pesquisa, a maioria dos jovens da rede pública estadual respondeu que "ser cidadão" era ser consumidor; na atual pesquisa eles apresentaram como a principal resposta "participar da vida política", o que também foi apresentado como a resposta mais apontada pelos jovens da rede particular. Com relação aos direitos, também foram observadas mudanças e duas questões chamaram atenção, a primeira com relação ao alto índice de jovens da rede pública que não souberam citar um direito (47\%), e a segunda com relação ao aumento nos exemplos de direitos civis. Explico melhor, enquanto na primeira pesquisa os jovens da rede pública citavam mais exemplos de direitos sociais e os jovens da rede particular citavam mais os direitos civis, na pesquisa atual, ambos apresentaram um repertório maior de direitos civis, tais como liberdade de expressão, liberdade de opção sexual, liberdade religiosa e direito de ir e vir, o que pode ser indício da vivência democrática de todos os jovens. 
A participação dos jovens em atividades extracurriculares também apresentou mudanças. Na primeira pesquisa o índice de participação em associações, partidos políticos e movimentos sociais foi maior do que o observado na pesquisa atual, o que nos levou à hipótese sobre a presença da internet no cotidiano desses jovens. Havia uma suspeita de que esse "esvaziamento" dos locais de participação mais tradicionais estivesse relacionado à migração para a articulação no ambiente virtual. Essa hipótese foi testada apenas nos grupos focais das escolas particulares, e o que pudemos observar foi uma visão bastante crítica desses jovens com relação à diferença entre uma participação concreta (ou física) e o que eles denominaram de uma "militância digital".

A percepção sobre os principais problemas do Brasil também mudou. Na primeira pesquisa, a violência era o principal problema apontado pelos jovens da rede pública e a desigualdade era o principal para os jovens da rede particular. Na pesquisa atual a desigualdade ainda está no topo da lista de problemas para os jovens da rede particular, mas a corrupção passou a ser o principal problema para os jovens da rede pública. Não pudemos averiguar até que ponto essa mudança na percepção dos problemas tem relação com o sentimento que esses jovens têm pelo país, mas o fato é que houve uma mudança expressiva nesse quesito. Na primeira pesquisa essa informação aparecia como uma simetria, visto que tanto para os jovens da rede pública quanto para os jovens da rede particular os principais sentimentos eram orgulho e inquietação, mas agora o principal sentimento apontado pelos jovens da rede particular é inquietação e para os jovens da rede pública é vergonha. Esses dados podem nos dar pistas para compor um dado novo que foi obtido na pesquisa atual, que é a motivação dos jovens para uma possível mudança de país. Enquanto quase $60 \%$ dos jovens da rede pública aceitariam uma mudança definitiva do país, apenas $30 \%$ dos jovens da rede particular compartilham dessa motivação, ficando a maioria desses com a opção de "morar fora" temporariamente. Quando o tema são as motivações para viver em outro país, os jovens da rede particular apontam como motivo principal a busca por melhores oportunidades de trabalho, enquanto para os jovens da rede pública a principal motivação seria a busca por um lugar onde as pessoas fossem mais respeitas.

Várias questões pedem aprofundamento. Uma que surge de forma premente é a questão da desigualdade racial brasileira, que está no bojo das desigualdades persistentes do nosso acordo social incompleto. Tal análise não pôde ser feita devido à limitação do campo com o surgimento da pandemia, quando os grupos focais foram interrompidos, mas certamente será ainda um tópico a ser explorado em análises futuras. 
Embora provisórios, tendo em vista que essa pesquisa possui um sólido banco de dados que certamente será retomado, os dados obtidos até aqui nos ajudam a confirmar o dinamismo e a dimensão plural da juventude, expõe o quanto as desigualdades presentes na sociedade refletem e impactam tanto na experiência de "ser jovem", quanto no seu espaço de participação para a garantia da cidadania. Além disso, a maior quantidade de mudanças do que de permanências, na comparação das percepções dos jovens nas duas pesquisas confirma o fator de ineditismo da vivência de cada juventude e reforça a importância de estudos contínuos para que sociedade e governos possam estar atentos à necessidade de garantir o direito à igualdade e à diversidade dessa parcela tão importante da população, a qual Mannheim brilhantemente chamou de "recursos latentes" por acreditar ser ela "uma potencialidade pronta para qualquer nova oportunidade". 


\section{Referências bibliográficas}

ABRAMOVAY, Mirian et al. Gangues, galeras, chegados e rappers: juventude, violência e cidadania nas cidades da periferia de Brasília. Rio de Janeiro: Garamond, 2002

ABRAMO, Helena. Conceitos fundamentais - ponto de partida para uma reflexão sobre políticas públicas de juventude / organizado por Helena Abramo. - Brasília: SNJ, 2014. 128p. ARENDT, Hannah. A Condição Humana. Forense universitária. Rio de janeiro, 1993.

BENDIX, Reinhard.A construção nacional da cidadania NewYork, Doubleday, 1969.

BOBBIO, Norberto. A Era dos Direitos. Campus, Rio de Janeiro,1992.

BOURDIEU, Pierre. 1983. Questões de sociologia. Rio de Janeiro: Marco Zero. P. 112-121.

BURGOS, Marcelo Baumann. A escola e o mundo do aluno: Estudos sobre a construção social do aluno e o papel institucional da escola. Garamond, Rio de Janeiro, 2014

CAIAFA, Janice. O movimento punk na cidade: a invasão dos bandos sub. Zahar editora, Rio de Janeiro, 1985.

CARVALHO, José Murilo de. Cidadania no Brasil: O longo caminho. Civilização Brasileira Rio de Janeiro, 2001.

Os Bestializados. Cia das Letras, 1991.

CARVALHO, Maria Alice Resende de. Cultura política, capital social e a questão do déficit democrático no Brasil" In: Vianna (org.) A democracia e os três poderes no Brasil. BH:UFMG, 2002

CATANI, Afrânio Mendes e Gilioli, Renato de Sousa Porto. Culturas juvenis: múltiplos olhares. Editora UNESP, 2008.

DA MATTA, Roberto. A casa e a rua, Brasiliense, São Paulo 1985.

DAYRELL, Juarez. O jovem como sujeito social. In: FÁVERO, Osmar; SPÓSITO, Marília Pontes; CARRANO, Paulo \& NOVAES, Regina Reyes (Orgs.). Juventude e Contemporaneidade. Brasília: UNESCO, MEC, ANPEd, 2007 Disponível em: http://unesdoc.unesco.org/images/0015/001545/154569por.pdf. Acesso em: 10 de janeiro de 2011.

DURKHEIM. Émile A divisão do trabalho social: Editora:Martins Fontes, São Paulo 1999 DURKEIM, Émile. Educação e Sociologia. 12a ed. São Paulo: Melhoramentos, 1955.

DURKHEIM, E. As regras do método sociológico. 13.ed. São Paulo: Nacional, 1987 
FERNANDES, Florestan. A integração do negro na sociedade de classes. 3. ed. São Paulo: Ática, 1978, v. 1.

FORACCHI, Marialice Mencarini. Educação e Sociedade: leituras de sociologia da educação [por] Marialice M.Foracchi e Luiz Pereira. $6^{\circ}$ edição. São Paulo, Compania Editora Nacional, 1971.

FLITNER Andreas. Os problemas sociológicos nas primeiras pesquisas sobre a juventude. In: Sociologia da Juventude (Vol. I): da Europa de Marx à América Latina de hoje. Zahar. Rio de Janeiro, 1968.

GIDDENS, Anthony. Sociologia uma breve, porém crítica introdução. Zahar Editora, Rio de Janeiro, 1982.

HOLANDA, Sérgio Buarque. Raízes do Brasil. José Olympio, 1991

IANNI, O. O jovem radical. In: Industrialização e Desenvolvimento Social no Brasil. Rio de Vitor Janeiro: Civilização Brasileira, 1963.

MARSHALL, TH. Cidadania, Classe Social e Status. Zahar. Rio de Janeiro 1967.

MARTINS, Heloísa Helena T. de Souza; AUGUSTO, Maria Helena Oliva. Juventude (s) e transições. Tempo soc. São Paulo, v. 17, n. 2, pág. 1-4, novembro de 2005. Disponível em<http://www.scielo.br/scielo.php?script=sci_arttext\&pid=S0103-

20702005000200001\&lng=en\&nrm=iso>. acesso em 04 de setembro de 2020. http://dx.doi.org/10.1590/S0103-20702005000200001.

MARX, Karl. Trabalho, juventude e educação politécnica. In: Sociologia da Juventude (Vol. I): da Europa de Marx à América Latina de hoje. Zahar. Rio de Janeiro, 1968.

MEAD, M. Coming of age in Samoa. Nova York: W. Morrow \& Company, 1928.

MANNHEIM, Karl. O problema da juventude na sociedade modernas. In: Sociologia da Juventude (Vol. I): da Europa de Marx à América Latina de hoje. Zahar. Rio de Janeiro, 1968.

MADEIRA, Felícia Reicher. Violência nas escolas: quando a vítima é o processo pedagógico. São Paulo Perspec. São Paulo, v. 13, n. 4, pág. 49-61, dezembro de 1999. Disponível em <http://www.scielo.br/scielo.php?script=sci_arttext\&pid=S0102$88391999000400006 \& \operatorname{lng}=$ en\&nrm=iso>. acesso em 04 de setembro de 2020. https://doi.org/10.1590/S0102-88391999000400006 
MOISES, José Álvaro; CARNEIRO, Gabriela Piquet. Democracia, desconfiança política e insatisfação com o regime: o caso do Brasil. Opin. Publica, Campinas , v. 14, n. 1, p. 1-42, June 2008 .

NOVAES, Regina. Juventude e religião: marcos geracionais e novas modalidades sincréticas.

NOVAES, Regina. Juventude e sociedade: jogos de espelhos. In: sociologia especial: Ciência \& Vida. Juventude brasileira. São Paulo: Editora Escala. Ano I, n. 2, 2007. p. 6 - 15. Disponível em : http://www.antropologia.com.br/arti/colab/a38-rnovaes.pdf. Acesso em: 10 de janeiro de 2011.

(Orgs.). Política Nacional de Juventude: Diretrizes e perspectivas. São Paulo: Conselho Nacional de Juventude; Fundação Friedrich Ebert, 2006. 140 p. 122

A juventude de hoje: (re) invenções da participação social. In: Associando-se à juventude para construir o futuro. São Paulo: Petrópolis, 2005. p. 107 - 147.

PAIS, José Machado. A juventude como Fase de Vida: dos ritos de passagem aos ritos de impasse. Saúde e Sociedade, v. 18, n. 3. São Paulo, 2009. p. 371 - 381. Disponível em: http://www.scielo.br/pdf/sausoc/v18n3/03.pdf. Acesso em: 10 de janeiro de 2011.

PAIVA, Angela Randopho. Juventude, cultura cívica e cidadania. Garamond, Rio de Janeiro, 2013.

. Católico, Protestante, Cidadão: uma comparação entre Brasil e Estados Unidos. Belo Horizonte: UFMG; Rio de Janeiro: IUPERJ, 2003.

reconhecimento e ação afirmativa no ensino superior. Civitas - Revista de Ciências Sociais, v. 15, n. 4, p. e127-e154, 2 mar. 2016.

.. Cidadania e formas de solidariedade social na favela. In: PAIVA, Angela R. \& BURGOS, Marcelo B. (Orgs.). A Escola e a Favela. Rio de Janeiro: Ed.

PUC-Rio: Ed. Pallas, 2009. p. 17 - 58

R. \& BURGOS, Marcelo B. Apresentação. In: PAIVA, Angela R. \& BURGOS, Marcelo B. (Orgs.). A Escola e a Favela. Rio de Janeiro: Ed. PUC-Rio: Ed. Pallas, 2009.

PAIVA, Vanilda Pereira - Educação Popular e Educação de Adultos-5a edição - São Paulo Edições Loyola - Ibrades - 1987.PUTNAM, Robert D. Comunidade e democracia: A experiência da Itália moderna. FGV, Rio de Janeiro 1996.

PUTNAM, Robert. (1996), Comunidade e Democracia: a experiência da Itália moderna. Rio de Janeiro, Fundação Getúlio Vargas. 
REIS, Elisa Pereira. Processos e escolhas: estudos de sociologia política. ContraCapa, Rio de Janeiro, 1998.

Desigualdade e Solidariedade, Uma Releitura do Familismo Amoral de Banfield. REVISTA BRASILEIRA DE CIÊNCIAS SOCIAIS, n. 29, p. 35-48, 1995

SANTOS, Wanderley Guilherme dos. Razões da desordem. Rocco. São Paulo 1993.

SAVAGE, Jon. A Criação da Juventude. Como o Conceito de teenage revolucionou o século XX (Tradução de Talita M. Rodrigues), Rocco, 2009.

SPOSITO, Marília P. Estudos sobre juventude e educação. Revista brasileira de Educação,]uvenwde e Contemporaneidade, n. 5-6,1997.

HALL, Stuart \& JEFFERSON, Tony (eds.). Resistance through rituals: youth subcultures in postwar Britain. London: Hutchinson, 1976.

SOUZA Jessé. A construção social da subcidadania: para uma sociologia política da modernidade periférica. Belo Horizonte, Editora da UFMG, 2003.

TAYLOR Charles. Argumentos Filosóficos. Loyola, São Paulo 2000.

TAVARES, Breitner. Sociologia da Juventude: da juventude desviante ao protagonismo jovem da Unesco, Goiânia, 2012.

TELLES, Vera da Silva. "Sociedade civil e construção dos espaços públicos". In: Anos 90: política e sociedade no Brasil. Evelina Dagnino (org). Editora Brasiliense. São Paulo, 1994.

TOCQUEVILLE, Alexis de, A Democracia na América. ED. USP, São Paulo,1989

TOURAINE, Alain (2009) - Poderemos Viver Juntos? Iguais e Diferentes. Vozes, Petrópolis, $2^{\text {a }}$ edição.

TURNER, Bryan," Outline of a Theory of Citizenship", Sociology, Exeter, 2, 1990.

VALLADARES, Lícia. Cem anos pensando a pobreza (urbana) no Brasil. In: Boschi, Renato (org). Corporativismo e Desigualdade: a construção do espaço público no Brasil. IUPERJ, Rio de Janeiro, 1991.

VIANNA, Hermano. Galeras cariocas: territórios de conflitos e encontros culturais. Rio de Janeiro: Ed UFRJ, 1997.

YINGER, J. Milton. "Contraculture and Subculture". In: American Sociological Review. Volume 25, número 5, outubro de 1960. Disponível em: «https://www.jstor.org/stable/2090136?seq=1\#page_scan_tab_contents». 


\section{Anexol.}

\section{I - Perfil do entrevistado}

Colégio:

Idade:

Série:

Gênero:

Estado de origem:

Vive com:-
(a) Um dos pais
(b) Ambos os pais
(c) Outro:
Número de irmãos:

Pretende fazer vestibular?

( ) $\operatorname{sim}$ ( ) não

Em caso positivo, você tem preferência por:

( ) universidade pública

( ) universidade particular

Qual curso?

\section{Escolaridade dos pais:}

Mãe

a) Ensino fundamental

b) Ensino médio

c) Graduação

d) Pós-graduação

e) Não sei informar

\section{Pai}
a) Ensino fundamental
b) Ensino médio
c) Graduação
d) Pós-graduação
e) Não sei informar

Lazer: enumere duas opções de lazer mais frequentes ( $\mathbf{1}$ para a mais frequente e $\mathbf{2}$ para a segunda mais frequente)

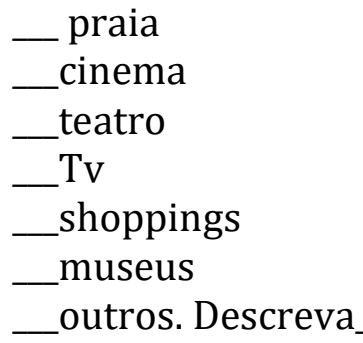


Sobre as atividades que você realiza na internet. Enumere:

(1) com muita frequência (2) em alguns momentos (3) quase nunca (4) raramente

( ) entretenimento (jogos, vídeos no youtube, filmes, séries).

( ) buscar informações

( ) ver e-mails

( ) conversar por aplicativos (Whatsapp, Menssenger)

( ) estudar

( ) trabalhar

( ) fazer compras

\section{II - Cultura cívica e valores}

Você participa de alguma atividade extracurricular no colégio?
(a) sim
(b) às vezes
(c) raramente
(d) nunca

Caso afirmativo, especifique o tipo.
(a) grêmio
(b) esporte
(c) ação social
(d) cultural

Atividade:

Você acredita que instituições políticas como Senado e Câmara ajudam a construir uma sociedade melhor?
(a) muito
(b) mais ou menos
(c) quase nada
(d) nada

Você participa da vida associativa do país? (Associações, grêmios, grupos)
(a) $\operatorname{Sim}$

(b) Não

Caso afirmativo, de que maneira?
(a) partidos
(b) movimentos sociais
(c) associações (grêmio, moradores, Ongs)
Outro:

Dentre as instituições abaixo, preencha de acordo com o número que corresponde o seu nível de confiança.
(1) muita (2) alguma (3) pouca (4) nenhuma confiança
( ) igreja
( ) militares
( ) partidos
( )polícia
( ) família 
De uma forma geral, qual o seu nível de confiança nas instituições brasileiras:
(a) muito
(b) alguma
(c) pouca
(d) nenhuma

O Brasil é sabidamente um país injusto. Você acha que nos últimos anos a situação está
(a) melhorando bastante
(b) as coisas estão mudando, mas a mudança ainda é muito pequena
(c) não está mudando nada
(d) está até pior

Frente a situação de desigualdade social no Brasil, você acha
(a)nada, porque sempre foi assim
(b)me incomoda, mas não posso fazer nada
(c)me incomoda, mas não sei o que fazer
(d)me incomoda e tento fazer o que está ao meu alcance

Qual o critério principal para a escolha da sua profissão?
(a) tem de me dar grande retorno financeiro
(b) fazer o que gosto mesmo sem garantir retorno financeiro
(c) perspectiva de sucesso
(d) ser útil à sociedade

Outros:

Quanto à questão racial no Brasil, em sua opinião:
(a) Não há preconceito racial, mas sim social
(b) vivemos numa democracia racial
(d) há preconceito tanto racial quanto social
(e) há preconceito racial

Você tem religião?
(a) $\operatorname{sim}$
(b) não
Qual? (opcional)

Frequenta cultos e cerimônias de sua religião?
(a) sempre
(b) ocasionalmente
(c) raramente
(d) nunca

\section{III - Percepção de cidadania}

Ser cidadão é:
a. exercer um cargo político na sociedade
b. participar da vida política e social do país
c. ser consumidor e ter o direito de usufruir dos bens que a sociedade oferece
d. uma ilusão
e. ser honesto
f. uma dificuldade num país como o Brasil 
Você tem consciência dos seus direitos e deveres como cidadão?
a. $\operatorname{sim}$
b. um pouco
c. não sei quais são
d. não me importa

Cite um dever de todo cidadão brasileiro:

Cite dois direitos que você considera

importantes: e

$\underline{0 \text { que você sente pelo seu país }}$
a. orgulho
b. vergonha
c. indiferença
d. inquietação
Outros:

Você considera o voto:
a. um direito político importante
b. é bom que seja obrigatório
c. deveria ser opcional
d. não adianta votar

$\underline{\text { Se você tivesse a oportunidade, iria viver em outro país? }}$
a. nunca
b. definitivamente
c. temporariamente para estudo ou trabalho

Caso, tenha respondido a opção "b" na pergunta anterior, responda as duas questões a seguir. Caso contrário, pule as próximas duas questões.

Em qual você gostaria de morar definitivamente?

Por que você gostaria de viver neste país?
(a) porque lá as pessoas são mais respeitadas
(b) porque lá existe mais oportunidade de trabalho
(c) porque lá existe mais segurança

Nação para você
a. é compartilhar cultura, história, valores
b. algo distante que não me diz respeito
c. só me interessa para eu viver a minha vida
d. outro: 


\section{IV - Avaliação da cultura política}

\section{Democracia é:}

a. o melhor regime para se viver em sociedade

b. bom só para país desenvolvido, pois nós precisamos de um governo mais forte

c. um mal necessário

d. algo que não me interessa

e. um regime no qual prevalece a corrupção e a violência

Fazendo uma avaliação da política, você diria que:

a. os políticos entram para a política para terem benefício próprio

b. embora se diga o contrário, a maioria cumpre com eficiência seu papel

c. em geral, são demagogos

d. cada sociedade tem os políticos que merecem

e. outro:

Ainda sobre os políticos:

a. não me representam

b. importantes para a democracia

c. são um mal necessário

d. outros:

Você vota?
a. $\operatorname{sim}$
b. não

Pretende tirar o título antes de completar 18 anos?
(a) sim (b) não

$\underline{0 \text { que irá te influenciar na hora de decidir por um candidato? }}$
a. plataforma do partido
b. ter certeza de que é honesto
c. minha família ou amigos me ajudam
d. trajetória do candidato

Você se considera informado sobre a situação política do país?
a. muito
b. mais ou menos
c. pouco
d. não me interessa 
Como se informa sobre a política? Enumere as duas fontes principais. (1 para a mais usada e 2 para a segunda fonte)
( )Família
( )Televisão
( )Redes sociais
( )Amigos
( )Professores
( )Por sites na internet
( )Não me informo

Os três problemas brasileiros mais graves são: (enumere em ordem de importância)

\section{Quanto à sua relação com as pessoas:}
a. até provar o contrário, acho que as pessoas são honestas
b. só confio nos meus amigos
c. hoje em dia a gente deve estar sempre com um pé atrás
d. não dá para confiar nem nas pessoas da minha convivência

Em um nível mais pessoal, três de seus maiores medos são:
( ) desemprego dos pais/responsáveis
( )contrair doença sexualmente transmissível
( )ser vítima de violência
( ) ter dificuldade de entrar no mercado de trabalho
( ) ter problemas familiares
( )não arranjar namorado
( )os problemas do país ficarem mais graves
Outros:

Ser jovem no Brasil é:
a. mais difícil que num país desenvolvido
b. apesar de tudo é bom porque as coisas ainda estão por ser feitas
c. igual a ser jovem em qualquer lugar
d. dá muita insegurança
e. outro:

\section{V-Temas gerais}

Sobre o aborto. Você considera:
a. um direito da mulher
b. um crime
c. um pecado

Casamento entre homossexuais.
a. um direito
b. uma aberração
c. um pecado 
Direitos da mulher.
a. ainda são discriminadas
b. já conquistaram todos os direitos
c. não sei opinar

\section{Perguntas acrescentadas}

\section{VI - Influência das redes sociais}

Por dia, você fica quanto tempo na internet?
(a) o dia todo. Visualizo meu celular sempre que aparece alguma notificação
(b) somente quando estou em casa
(c) menos de uma hora
(d) não sei dizer
(e) no máximo três horas

Em sua opinião, as redes sociais:
(a) não são o melhor ambiente para falar de política
(b) possibilitam uma melhor participação nos assuntos sobre política
(c) criam uma falsa sensação de participação política
(d) são perigosas e precisam ser usadas com cuidado

\section{Nas redes sociais, você costuma:}
(a) publicar fotos próprias
(b) compartilhar notícias sobre política
(c) compartilhar notícias sobre assuntos variados, exceto sobre política
(d) não compartilha nada, mas curte ver as publicações dos amigos

Com relação ao compartilhamento de notícias, você:
(a) se preocupa em pesquisar a fonte da notícia
(b) não se preocupa em pesquisar a fonte da notícia
(c) compartilha direto se a notícia foi divulgada por algum amigo ou parente
(d) compartilha direto se concordar com a notícia

\section{VII - Influência da Sociologia enquanto disciplina obrigatória}

Você tem aula de Sociologia?
(a) $\operatorname{sim}$
(b) não

Qual a carga horária de semanal de Sociologia aqui na sua escola?
(a) um tempo de aula por semana (45/50 minutos por semana)
(b) dois tempos de aula por semana (90/100 minutos por semana)
(c) outro. Cite:

Com relação a disciplina Sociologia, você
(a) considera importante
(b) considera importante, mas com pouco tempo (carga horária semanal) 
(c) não considera importante

Cite, pelo menos, três temas que você já estudou em Sociologia 


\section{Anexo II}

Departamento de Ciências Sociais - CIS/PUC-Rio

Roteiro para grupo focal - Projeto de Pesquisa para Dissertação de Mestrado

Título: Juventude, Cultura Cívica e Cidadania

Linha de Pesquisa: Cidadania, Direitos E Desigualdade Social

Aluna: Michelle de Moraes Ferraz Orientadora: Angela Rodolpho Paiva

\section{Procedimentos gerais:}

- Gravar a informação sobre data, nome da escola, nome dos condutores e relatores.

- Registrar a quantidade de participantes.

- Fazer a apresentação para os participantes esclarecendo os objetivos da pesquisa, e como está sendo realizada.

- Assegurar que o material gravado será de uso exclusivo da pesquisa sendo assegurado o anonimato dos participantes.

- Estabelecer um diálogo preliminar visando descontrair os participantes. Por exemplo: indagar se já participaram de algo parecido.

- Lembrar que é fundamental que fale apenas um de cada vez.

- Observar que o grupo focal deve se desenvolver como um debate de ideias, e que, portanto, todas as opiniões são importantes, e que não é uma prova oral ou algum tipo de avaliação.

Sendo assim, é importante fazer com que todos falem.

Tema 1 - Sentimento pelo país. (10 min)

- Para começar a conversa, gostaríamos de saber que tipo de sentimento o Brasil desperta em cada um de vocês (tentar capturar uma percepção de medos, problemas e expectativas).

Tema 2 - Confiança nas instituições. (10 min)

- Nossa primeira pesquisa indicou que os alunos apresentam índices diferentes de confiança, dependendo da instituição que é perguntada.

Entendendo instituições como "corpos" de estrutura e normas sociais, procurar identificar o nível de confiança nas seguintes instituições:

Igreja, família, escola, universidade, judiciário, polícia, militares.

Quais elementos causam desconfiança e quais elementos causam confiança nas instituições de uma forma geral.

Tema 3 - Formação da percepção sobre a sociedade. (10 min)

- O Brasil é sabidamente um país desigual. De que forma vocês acreditam que esta desigualdade atinge vocês?

- Vocês acreditam que a democracia pode ajudar a tornar o Brasil um país mais justo?

Tema 4 - Cidadania e participação. (10 min)

- Vocês participam de alguma atividade extracurricular? Quais?

- Acreditam que é importante participar de atividades como estas?

- Esta escola estimula este tipo de participação?

- Quais são os fatores que impedem ou impediriam uma participação maior?

- Como vocês definiriam "ser cidadão"? 
- Vocês acreditam que é mais fácil ser cidadão hoje ou quando seus pais eram jovens?

- Quais são as expectativas e quais são os desafios em ser (hoje) jovem no Brasil?

\section{Tema 5 - Internet e Sociologia (temas adicionados). (10 min)}

- Vocês acreditam que internet pode ajudar as pessoas a participarem mais de assuntos relacionados a cidadania?

- Como vocês fazem para checar a veracidade de uma informação na internet?

- Vocês já responderam ou criaram alguma mobilização pela internet?

- Atualmente vocês acreditam que obtém mais informações pela internet ou por outros meios (conversas com os pais, amigos escola)?

- Qual importância vocês atribuem para a disciplina Sociologia enquanto conteúdo curricular? 


\section{Anexo III}

\section{Lista das escolas participantes}

Escolas públicas da rede estadual

- Colégio Estadual Amaro Cavalcante

- Colégio Estadual André Mourrois

- Colégio Estadual Infante Dom Henrique

- Colégio Estadual Prado Junior

\section{Escolas públicas da rede particular}

- Escola Nova

- Escola Parque (Gávea)

- Escola Parque (Barra)

- Colégio São Vicente de Paula

- Colégio Palas 